\title{
“A Most Extraordinary Man”: Alexandro Favián’s Letters to Athanasius Kircher, 1661-1674
}

\author{
By
}

Nancy E. Márquez

\begin{abstract}
A 120-point thesis
submitted to Victoria University of Wellington

in fulfilment of the requirements for the degree of

Master of Arts in Literary Translation Studies
\end{abstract}

Victoria University of Wellington - Te Herenga Waka

School of Languages and Cultures

2022 


\section{ATHANASII KIRCHERI \\ E SOC. IESV. MAGNETICVM NATVRAE}

\section{R E G N V M}

\section{S I V E}

DISCEPTATIO PHYSIOLOGICA

De triplici in Natura rerum MAGNETE, iuxta

uriplicem eiufdem Naurx gradum digefto

I N A I I A T O

$A N$ I M A T O

SEN S I T I V O

$$
\text { Q u a }
$$

Orculta prodigiofarum quarundam motionum vires \& proprietates, qux in triplici Naturx Oeconomia nomullis in corporibus nouiter detectis offeruantur, in apertam lucem eruuntur,

\&. luculentis argumentis, experientia duce, demonftrantur.

A d

A d Eximium Virim

ALEXANDRVM FABIANVM Noui orbis Indigenam .

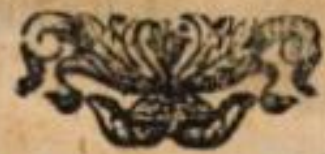

Romx, Typis Ignatij de L azar is . 1667 . Sup. Permiff:

Titlepage from Kircher's 1667 publication Magneticum naturae regnum, which he dedicated to the author of the letters translated in this thesis: Alexandro Favián.

Public Domain image from Google Books. 


\section{Abstract}

This thesis is an annotated translation of seventeenth century letters composed in early colonial Mexico and posted to Europe by the novohispano Alexandro Favián. An active reader of the German Jesuit scholar Athanasius Kircher's encyclopedic works about scientific curiosities, Favián wrote eleven letters totaling over one hundred handwritten pages between 1661 and 1672; my annotated translation includes eight of them in their entirety. The letters were sent from Puebla de los Ángeles, near Mexico City, to Rome during the last few decadent years of King Philip IV's reign and, following his death in 1665, during the regency of his wife Mariana of Austria for their son Charles II. These were years of economic recession for many European states and, for Spain, a period of political uncertainty. For New Spain, after the corrupt viceroy Juan de Leyva y de la Cerda was recalled to Spain for his abuses, a relatively stable viceregal term began with the Marquis of Mancera (r.16641673) whose court in Mexico City was famously visited by criollo intellectuals Don Carlos Sigüenza y Góngora (1645-1700) and Sor Juana Inés de la Cruz (1648-1695).

Favián's long-overlooked letters are worthy of study for two main reasons. On the one hand, because they give readers an insight to the trials and tribulations of a cleric of a certain social standing but who, despite the relative wealth and comfort of his upbringing in colonial New Spain, was denied opportunities for professional advancement. The customs and appointment practices of the Spanish empire excluded most non-Europeans from advancing in professional roles which might wield any kind of political influence as the higher church posts did (Arias, 2003). On the other hand, his collection of letters is notable because not only do they discuss books about early modern science, but also describe curious machines such as self-playing organs, binoculars, and geared alarm clocks. Thus, Favián's correspondence could be read as a fine example of how Kircher's works were received and used in the Americas. Indeed, the collection of letters suggests that Favián sought to distinguish himself locally, in New Spain, as a collector of scientific materials motivated by educational objectives.

This project makes three significant contributions. First, I examine how fluid positionality within a metropole-periphery dynamic was leveraged by colonial writers to negotiate the exchange of scientific ideas and objects with other figures more centrally situated. Second, I offer a case study of reader reception for Kircher's prolific output. Finally, I make a seventeenth-century colonial author's words available in English with a scholarly apparatus for the first time. This thesis consists of two main sections: in the first are notes about Favián's letters and their translation, and in the second are the translations themselves as well as annotations followed by a bibliography. 


\section{Acknowledgments}

I would like to express my sincere and enthusiastic thanks to my supervisor, Dr. Carolina Miranda, for her expert guidance throughout the research and writing stages of this thesis; her feedback and drive have improved it immeasurably. Carolina's willingness to advise a student of seventeenth-century colonial texts is a testament to her prowess with both Latin American literatures and the discipline of Literary Translation Studies, all of which enriched my thinking tremendously.

Dr. Miranda, Dr. Anita Brady and Dr. Megan Evans eased my journey by making it possible for me to tutor in a range of Spanish language courses as well as for FHSS103: Great Ideas. Teaching and learning alongside undergraduates have been a genuine highlight of my experience, and the staff at both the Language Learning Centre and the Centre for Academic Development made excellent pedagogical tools accessible to me when they were most useful. A university grant funded a research trip to the Puebla archives, where the Ayuntamiento archivist Luisa Reyes and paleographer Arturo Córdova Durana graciously shared their knowledge of relevant documents with me.

Additionally, I would like to thank the School of Languages and Cultures, Dr. Sally Hill, Dr. Nicola Gilmour, Dr. Limin Bai, Lisa Lowe and the administrative staff, especially Ida Li, for providing timely encouragement and ample resources for the completion of this work. Dr. Jeff Tatum and Dr. Marco Sonzogni were instrumental in sparking my desire to undertake Favián's letters as a degree project, and Dr. Diana Burton, Christina Hyson, and Brent Stone at the Faculty offices, as well as Rohini Biradavolu in the university library, provided crucial assistance in the final months of this thesis. My gifted and scholarly coffee-walking buddies Dora, Tory, Niusila, Clara, Mi Young \& Stephen, Rachael, and Hilary reminded me how much fun it is to discuss research.

This thesis is dedicated with love to my husband and daughter whose support made it possible. 


\section{Part I: Introduction}

This thesis is an annotated translation, from Spanish, of letters written by a seventeenth-century clergyman, Alexandro Favián (1624 - c.1700) in New Spain. To my knowledge, it is the first translation into English available for consultation. In what constitutes the first in-depth, contextual study of Favián's letters to Rome, I have probed sources such as historic maps and dictionaries, scholarship about Favián's hometown and time, and my own research on Favián's family in the Puebla de los Ángeles archives. The following introductory commentary should assist the reader in situating the text historically. The annotations, which accompany each letter, constitute a cultural translation of the corpus (that is, the collection of letters) and provide further socio-cultural backdrop of the milieu as well as references to scholarly sources.

Favián's series of letters to or from Rome between 1661 and 1682 were digitized from the Jesuit archives in Rome by Stanford University in 2013, which makes them accessible online as part of the Kircher Correspondence Project and Stanford's Mapping the Republic of Letters site. (A subset of these is available via the Early Modern Letters Online catalogue.) Here, I build on Ignacio Osorio Romero's work, expanding the transcripts of the only dedicated publication about Favián to date, Osorio Romero's La luz imaginaria. Epistolario de Atanasio Kircher con los novohispanos (1993), a collection of nearly sixty letters composed by, addressed to, or concerning Favián. While Osorio Romero added thirty-eight pages of Introduction to the letters, the work lacks comprehensive annotations, images of the letters, and biographical content from other documentary sources that the historian would have likely included if the compilation had not been published posthumously. In translating these letters from Osorio Romero's transcriptions and the digital images, my project aims to make the letters available in English to students and scholars of early modern science and colonial Mexico.

The work of scholars such as Ignacio Osorio Romero (1991; 1994), Elías Trabulse (1994a; 1994b), Miruna Achim (2001; 2011), Karla Jasso (2013), José Pardo-Tomás (2016), and Victoria Ríos Castaño $(2015 ; 2018)$ has begun to shed light on colonial New Spain as a rich and interesting area for research on early modern science. In the past, the study of the dissemination and local development of science in colonial New Spain has been hindered by source accessibility. Favián's letters offer a firsthand account of the income instability which many educated and resourceful criollos experienced regardless of their family backgrounds in New Spain. They also offer a personal depiction of everyday life in Puebla in the mid-late seventeenth century. Throughout the annotating and contextualizing, my primary focus has been to translate Favián's letters in a way that will contribute to the study of science in colonial New Spain.

Alexandro Favián, was a science hobbyist with a keen interest in the technological advances of the time who donated his family inheritance to beautify local churches. His long-overlooked letters detail the anguish of a cleric in his early to mid-forties who was born into a certain social standing 
which was, despite the relative wealth and comfort of his upbringing in colonial New Spain, lacking in opportunities for professional advancement. As a proto-scientist and a man of the Church, Favián sought out his career advancement by contacting powerful friends in Rome. Worries about his selfworth and declining financial prospects almost certainly kept him from finishing a 1,000-page book summarizing contemporary scientific ideas entitled the Tautología extática in homage to Kircher's influential Iter extaticum as well as Favián's smaller 250-page work on the composition of light (Osorio Romero 1994†, 86). Favián and his well-known correspondent Athanasius Kircher (16001680) 10,200 kilometers away in Rome, wrote to each other about scientific books and potential benefices for thirteen years, but they never met. Kircher was a prolific author of works about an extensive range of early modern science topics sometimes referred to in the scholarly literature as baroque science or Jesuit science (Mordechai 2003; Prieto 2011; Chen-Morris 2014; Gorman 2020). Despite not having the full record of Kircher's responses available to date, it is clear that Favián's plans to secure a tenured post within the church hierarchy of New Spain fell through. It may be the case that his boastful personality earned him the envy and disdain of some of his colleagues, but as we argue later, the set of letters also reveal the political dynamics in place at the time.

As a collection, these letters also provide insights into a period in the life of a little-known figure with distinctive interests and habits. Arguably, the fact that they are not intended for public reading makes Favián's accounts even more important. A man of science, of sorts, Favián wanted to understand the whys and hows of light, sound, and magnetism. He sought recognition from his peers and superiors for his generous and pious efforts. And he hoped for clerical career advancement of an ideal type: a bishopric that was not too far away or too poor, nor one that was considered by others to be too desirable or prestigious. On the one hand, these letters render the concerns of Alexandro Favián, a professional confessor for local convents and religious orders, essentially a contract-worker, who is struggling to make his professional and personal contributions visible and to secure his financial-future. On the other hand, they also serve to illustrate how his dialogic friendship with Kircher spurs dramatic changes in his life and increases his willingness to take financial risks. At moments the letters are personal and autobiographical in tone, but they also constitute book reviews since Favián often discusses how the scientific texts available to him help him to cope with the disappointments of failing to secure a local church sinecure which would have maintained his family's wealth and status.

Notably, the letters highlight the structural problem which forces Favián to be resourceful about career advancement by portraying glimpses of the political environment within which he lived. Thus, they illustrate a larger political issue for locals in New Spain, namely, not being allowed to serve in the highest positions of power whether in civil government or the church hierarchy. New Spain, which is Mexico today, was during its first three centuries a colony of Spain which means that the upper echelons of its political and clerical leadership were born, exclusively, in Europe (Arias 2003, 42). Local criollo candidates for these roles were not considered even when they were the sons 
of Spanish nobles because they had grown up in the colonies, which meant that they could not be trusted to further the interests of imperial rule (Cañizares 2006, 64ff.). As scholars such as Cañizares and Masters point out, wealthy criollos did their best to influence or subvert their fixed-term governors in establishing new institutions but would need to be creative in their methods (More 2012; Cañizares and Masters 2022). In the period 1810 to 1820, a century after Favián's death, the social class composed of the second, third and fourth generation children of Spanish and mixed parents declared their political independence from Spain.

Additionally, the letters also show Favián as a book reviewer of sorts, serving as testimony of the reception of Kircher's thirty-five encyclopedic, folio-sized books in New Spain. At a rate of just under one new work per year, the Jesuit cleric and author of early modern scientific books, Athanasius Kircher wrote a dizzying array of works on varied scientific topics of the premodern era including bioluminescence, volcanoes, exotic languages, self-playing musical instruments, and even clocks which worked like flowers to track the movement of the sun across the sky (Leichtentritt 1934). Thus, read all together, the surviving collection of letters reveals that Favián is a rather surprising figure within Athanasius Kircher's vast network of correspondents. From among Kircher's hundreds of correspondents, 2,686 records of letters to or from the Jesuit scholar are housed in Rome, mostly at the Pontifical Gregorian University (Fletcher 1988; 2011; Stolzenberg 2001, Findlen et al., n.d.), Favián managed to gain Kircher's openness to a twelve-year epistolary exchange despite his relative marginality within the scientific community of the time. The topics of the correspondence range from a shared love of scientific knowledge to a commercial interchange about material goods, primarily scientific instruments. Because of the nature of the letters, annotating them provides the relevant context, namely, to highlight the reception of Kircher's works outside the rarefied communities of European science where his books frequently circulated (Stolzenberg 2013, 161). On the one hand, Favián's letters allow us to understand how Kircher's books may have been read (and used) by non-specialists during the author's lifetime. On the other, this correspondence underscores how Favián engaged with the scientific discourse of the epoch from his relatively peripheral position. Indeed, Favián was neither a recognized scientist nor was he located in the capital city of New Spain, where the technological advances of Europe arrived in the greatest quantities. Nevertheless, I posit that, differing from Paula Findlen's reading (2004 p.340), Favián's letters show the ways in which Kircher's encyclopedias were used as textbooks, like modern DIY handbooks, for education and diversion. It is in that respect that my annotated translation could contribute and be of interest to scholars of early modern science in general and to historians of early colonial Mexico specifically. 


\section{Notes on Alexandro Favián's Letters}

"Inclytum et eximium virum novi orbis" (Kircher 1667)

In a dedication to his epistolary friend Alexandro Favián in Magneticum naturae regnum (1667), Athanasius Kircher referred to him as "inclytum et eximium virum novi orbis," famous and exceptional man of the New World. As a relatively successful cleric in Puebla de los Ángeles, Favián lived in one of the few seventeenth-centuries cities of North America that saw itself as competing with Mexico City in the category of sophisticated book collections (Rueda-Rodríguez 2009; Leonard 1947 p.403f). He wrote approximately fifteen letters to Athanasius Kircher in Rome, eleven of which were found in the early 1990s by the Mexican historian Ignacio Osorio Romero. Osorio Romero transcribed Favián's letters from Athanasius Kircher's epistolary collection at the Jesuit Archives in Rome and passed away while serving as director of the Instituto de Investigaciones Bibliográficas. The Instituto published Osorio Romero's transcriptions and introductory notes posthumously, and the set of missives which the historian transcribed are yet to be fully appreciated.

The significance of a close reading of Favián's letters as the one I propose here lies in their very personal depiction of a much larger problem facing the Spanish colonies, that of locally born governors and clergymen who felt that they were prevented from progressing in their careers by externally appointed superiors. A close reading of the missives reveals that the reason why Favián was unsuited for promotion, according to an unkind contemporary, was that he was an americano and so lacked a certain demeanor which was presumably due to his mercantile background. Nevertheless, Favián claims in the letters that he has seen "much worse" clerics than himself appointed from abroad to nearby bishoprics. As Cañizares points out, a discourse of "unfavorable constellations" was used as a shorthand by Europeans stationed in the Spanish Americas to discount the potential of locals (2006, 64ff). The letters describe the lengths to which Favián went, to try and secure a bishopric or other position with a stipend and how he sought help from Kircher in Rome to gain an appointment but did not succeed. That locally born careerists with the requisite education, training, and experience were consistently overlooked by their superiors in favor of European candidates, is perhaps not a surprise to the modern reader but would have been a weighty issue to the emergent criollo psyche; thus, my annotations will contribute to unpacking these issues. As such, these letters from a little known novohispanic cleric, ostensibly about scientific instruments, and books of early modern science, lay bare the roots of contention which later spurred colonial Independence.

Interestingly, Favián appears not to have travelled with frequency to the capital; the letters suggest that he may have sought to establish himself as the hub of a local network of experimentalists, apprentices, and educated priests and seminarians within his hometown, and New Spain's second city, of Puebla. A priest and a man of faith, he nevertheless invested his entire inheritance in the material aspects of religious observance and also promoted the intellectual development of his community. $\mathrm{He}$ 
does not specifically describe his private library and museum as an educational institution, yet these ends cannot be separated from his drive to display knowledge in a grandiose manner. However, it is clear from what he tells Kircher what the items mean in terms of learning as well as cultural capital as he sought to promote this set of values within a localized community where he might be admired.

Read as an autobiographical account, the letters may at times be best understood using Stephen Greenblatt's concept of Renaissance self-fashioning (1980) wherein the subject is an agent of their own transformation and uses the written word to fashion a public persona which suits the ideals of a particular social environment (Cruz 1992; Luciani 2004; Kirwan 2016). When Favián attempts to first establish an epistolary friendship with Kircher, he reveals only selected aspects of his persona. For example, Favián does not tell the story of his parents and only refers to his five siblings in passing, though it is clear that two of his sisters were nuns and one of his brothers was ordained a priest during the years of letter-writing. A more elaborate autobiographical backdrop might have explained his inclinations for exuberant display and his clear preference for solitary hobbies, however, these explanations are lacking from the letters. Based on his letters we know that he was an ordained priest and worked as a confessor. He also invested his inheritance in rebuilding and furnishing the chapels of Puebla's Vía Crucis, and a small plaque at one of the chapels notes his investment (Ruiz Martinez 1992). His collection of Kircheriana seems ultimately intended for educational purposes in addition to his own personal use and delight. Favián describes his new museum space, as a "sala" which he is having built to house his collection of impressive books, scientific instruments such as telescopes or microscopes, and curiosities, of which the musico-mechanical seems to be his preference. Favián's display would have also included his exceptional seashells (Rueda-Rodríguez 2004a; King 2001). Shells formed part of the Medici cabinet of curiosities and were popular among a certain class of collector during the early modern period (Bass 2021). Favián's seashells must have been exceptional since Kircher printed within his Magneticum naturae regnum 1667 a discussion of an exceptional seashell which Favián had sent to Rome, and Kircher also dedicated the work to Favián whom he refers to as a "most extraordinary gentleman" from the New World.

As a collector of curiosities, Favián seemed in tune with what was happening in the Old World. In seventeenth-century Europe, cabinets of curiosities (often referred to by scholars as wunderkammern) were fashionable among intellectuals and others with the resources to display exotic natural objects, works of art from far off places, or other interesting items. Rudolf II had a sizeable one in Austria with a room dedicated to tokens from the Spanish colonies (Eamon 2017; Van Cleempoel 2009), and Kircher famously had one in Rome which was among the first to be referred to using the term "museum" (Findlen 1995; 2001), but it took another century for collections of comparable stature to be established in New Spain. For example, the elegant library of the Palacio de Minería built between 1797 and 1813 in the historic center of Mexico City can still be visited today for a glimpse at how European fashions influenced what counted as knowledge even multiple decades past the trend's heyday (Acervo Histórico www.mineria.unam.mx). Indeed, the cabinets of Europe 
frequently contained objects collected or produced in the Americas and East Asia because these novelties were transported in the same ships from Veracruz and included items that had arrived at the Pacific port of Acapulco (Flynn 1996, 2017; Davids 2011; Bonialian 2012 Gasch-Tomás 2014; Peterson 2014; Aram 2014). The wunderkammer of Madrid, still on display at the Museo Nacional de Ciencias Naturales as the Real Gabinete de Historia Natural, is an example of a nineteenth-century cabinet of curiosities prepared by an enlightenment-era Ecuadorean, Pedro Franco Dávila (17111786), who was contracted to gather exotica from across the seas (Arinero 1988; Bleichmar 2021).

Favián's drive for acquiring objects both as a status symbol and to satisfy his scientific curiosity is evidenced by the consistency with which requests for scientific instruments, books, and other objects appear in his letters. Indeed, in his third letter, dated 23 August 1664, he asks for catoptric mirrors and a helioscope to fulfill his ambition to create what he refers to as a "museo." Though it is not clear what kind of visitor his museum was open to, his letters do mention that he had visitors arrive at his door in order to see his collections on a daily basis for an extended period of time. The son of a wealthy Genoese merchant who appears to have remained within a small radius of his family home despite the desire to travel for professional fulfillment, Favián insists upon the best available quality in book bindings, copperplate engravings, scientific instruments, and religious artworks. And these preferences offer the reader an insight into his personality and upbringing. That he feels so free to write long lists of requests to a person whom he has never met may be an outcome of perceiving Kircher as being a more successful version of himself: an experimentalist who is also entrepreneurial and a self-promoter (De Sepibus 1678; Findlen 2004). Kircher, like his intellectual contemporaries did within their European networks, sent unsolicited copies of his latest publications to the Jesuit colleges in Africa, India, East Asia, and the Americas. By doing so, Kircher had his works added to libraries at the furthest reaches of the globe (Fletcher 2011, p.235). Favián registers Kircher's apparent wealth, books were costly goods after all, and does not show any qualms about asking for "too much" nor does he seem hindered by the thought of incurring debts.

Indeed, Favián's letters start out with requests for items which he can pay for, such as books and scientific instruments, but over time his requests evolve into commentaries on matters of greater socio-political complexity, such as suggesting that criollos were an underutilized resource for managing the affairs of New Spain. He also urges Kircher to help him attain a bishopric as he seemed unable to advance his career through his own, local contacts. In fact, Favián was not mistaken when revealing the powers at play: only one criollo, Alonso de la Mota y Escobar managed to achieve what Favián was after (Andreu 2019, 863f). And in the process of making these repeated requests for favors, Favián bypasses his local superiors, in particular, Francisco Ximénez (born François Guillot c.1601 and an old acquaintance of Kircher's at the University of Lyon), who had first introduced Favián to Kircher. Ximénez was subsequently promoted to the politically influential position of confessor to the viceroy in Mexico City, where he could have been a powerful ally had Favián satisfied Ximénez's Old World requirements. How Favián could have behaved so audaciously as to 
aspire beyond his standing, is explained in The Radical Spanish Empire: Petitions and the Creation of the New World by Jorge Cañizares-Esguerra and Adrian Masters, where the authors analyze the development of an emergent social order that was "deeply alien to Iberia and much of Europe" (2019, n.p., https://radical-spanish-empire). Cañizares and Masters examine archived petitions from the 1530 s to the 1570 s in their research, presenting a story of a social order which allowed for a surprising degree of social mobility: from the early colonial period, people from across the social strata had a notable degree of access to the crown via paperwork and persuasion. The historians argue that scholars have long miscategorized the Spanish empire as a hidebound antithesis to some imagined liberal, modern, and democratic rule under anglophone empires, rather than making sense of how radically experimental the Spanish colonies were (2019, n.p.). For Cañizares and Masters, the historical archives they analyze, not only document the loss of conquistadors' political power, but also the options available to commoners who knew how to use the paperwork structure to petition for official titles and to secure land grants from the crown. Rather than being exclusively a top-down structure of government, their research has found that in many cases, the crown's decrees were responsive, bottom-up, and led by petitions from vassals. This radical social order consisted of the strategic use of three key elements: paper, silver, and persuasion and explains in part the shock and disdain recorded in texts produced by Europeans living in New Spain during that century. They argue that by the year 1600, three decades before Favián's lifetime, "any individual who had royal favor, a robust personal archive, and money could secure status and generally overcome challenges about their status and ancestry" (2019, n.p.).

Paperwork, silver bars, and persuasive rhetoric aptly describe Favián's attempts at receiving a benefice during the third quarter of the seventeenth century. Reading Favián's correspondence from the perspective of Cañizares and Masters, it is clear that Favián too participated in the process whereby status was "commodified" in the new culture that emerged in colonial Mexico. New Spain was the site of a uniquely novohispanic culture, where aristocratic privileges were petitioned for by a wide spectrum of the population and many times, indigenous land claims were granted to those with sufficient paperwork. We know from his letters that Favián believed in the power of abundant and repeated paper petitions. It is also evident from his letters that he understood the workings of bureaucratic hierarchies and exploited their loopholes by way of personal relationships: he used his outsider positionality in relation to the Jesuit order to bypass its many levels and to access the highestranking members of its network. According to Cañizares and Masters (2016, n.p.), along with social mobility by way of archive-production came a sophisticated form of "textual skepticism" which is perhaps at the heart of Favián's self-doubt when he fears that his correspondence with Kircher will be perceived to have been a fantasy because their efforts to secure a bishopric for him do not materialize. In his later letters, Favián fears that his overly long and often repetitive letters are insufficient to achieve his goal. He was heartily criticized by Ximénez for a typically novohispanic approach to status and social climbing, "el genio bárbaro de los americanos," in a letter to Kircher dated 26 
October 1666 and 8 May 1672. Not being constrained by an old-world mentality of social fixedness, whereby individuals were bound to the social roles filled by their parents, made Favián subject to criticism by Ximénez and possibly other superiors within Puebla.

Over the course of nearly a decade and a half, as Favián and Kircher's epistolary acquaintance becomes a friendship, the letters display an urgency about establishing Favián's good lineage through an uncle whose elite position within the Jesuit order and this connection may have motivated or prolonged Kircher's participation in the correspondence. While Favián's early letters mostly gush with emotional energy, after 1672, the only extant letters transcribed by Osorio Romero were letters written from Rome to Favián to let him know that his desired bishopric seemed to not be part of providence's plan. Careerist aspirations aside, Kircher's final letter to Favián in 1674 reads like that of one friend to another with an interest in sharing the moment's concerns, encouragement in the disappointments of a failed endeavor, and his current state of health.

Read all together, it is evident how Favián adjusts his rhetorical strategies to suit his changing requests as well as his perception of Kircher's potential responses. At times, he depicts Puebla as a place where scientific tools would be extremely rare, at other times he conveys a great, and inexplicable, familiarity with a range of scientific books and European luxury items. In fact, many of these works may well have been in local collections, as by 1664 the Bishop of Puebla's library (the famed first public library in the Americas, the Biblioteca Palafoxiana) held 5,000 books - books which were literally around the corner from Favián's family home on the main square. Moreover, the letters convey not only his efforts but also his likeably earnest desire to connect with the object of his scholarly estimation, namely Kircher, over matters of scientific curiosity. The final letters retain Favián's characteristic openness and enthusiasm for a variety of exploratory objects from the more technical topic of helioscope lenses to the merely delightful or surprising as when he requested convex and concave mirrors for setting up a display of optical illusions in his museum which he hopes will capture the spirit of Kircher's in Rome (Schechner 2005; Steadman 2021).

Very little is known about what happened to Favián in his final years. Although scholars have not yet found evidence of how he lived the last years of his life, we can hope that Favián's siblings forgave him his foolhardy sale of their family hacienda (a term which Favián uses consistently to refer to properties and an inheritance) and came to his aid, without disdain, when he was in financial need. Archival documents found in the Archivo Histórico Municipal in Puebla show that after his father passed away, Favián appears alongside his widowed mother in petitioning for the repayment of debts owed to the deceased by the city council (Ayuntamiento: no. 04482; ficha no. 06733). Based on the concerns he expressed in various letters about his siblings' finances, Favián appears to have been entrusted to manage these funds in fiscally responsible ways. It is reasonable to speculate that this could be this reason that his unrestrained generosity with the chapels and stations of the cross in Puebla left him desperate to save face by finding a church position which would pay him a reliable stipend: his youngest brother was a poet who could not but live off the family's hacienda and two of 
his sisters were nuns at the type of convent where the daughters of wealthy families stayed and which depended on the regular contributions of those families for their comfort and upkeep.

Favián's moments of apparent desperation led his former friend and superior Francisco Ximénez to write that Favián was a dissembler. Whether due to personal or political motivations, it is ironic that the person who had once recommended Favián to Kircher in 1655, is the same Ximénez who later writes that Favián not did deserve the accolades with which Kircher had praised him. Osorio Romero points out that Favián was a typical criollo, always attempting to build up his reputation and his list of merits to attain royal gracias in the form of a noble title, tenured post, or church benefice (1993, p.xxv). While tepid in its implicit critique, Osorio Romero's reading also seems to miss the particularities of Favián's dire financial situation. When writing about Athanasius Kircher's readers in New Spain, historian Paula Findlen, asserts that Favián appears to have had an "alarming" fixation on Kircher which might be called "insanity" (2004, p.340, 342). Combining a close reading of the letters with exhaustive research, I suggest instead, that for his professional advancement Favián appears to have exploited the 'paper, silver and persuasion' system which, as discussed earlier, for Cañizares and Masters dominated during the early colonial period; after all, silver and lengthy, rhetorical missives were tools that Favián had at his disposal. Based on his letters during the years that he was in correspondence with Kircher, Favián clearly took on significant financial risks, which unfortunately for him, did not pay off. Thus, he gambled on Kircher's influence in Rome. His letters also give accounts of the ways in which he faced unexpected setbacks when his splendid displays of religious philanthropy brought him the envy rather than the support of his peers in Puebla.

Whether Favián was as duplicitous as Ximénez describes him in later letters to Kircher or he was a victim of conflicting social norms and financial insolvency is up for debate. Thus, the extant letters provide a Rashomon-type story without resolution posing more questions than answers. In any case, they provide further insights into interclass tensions and even shipping irregularities at ports. For example, Favián's courier and long-time family friend, Francisco María Tassara complained in his final letter to Kircher about Favián's delay in paying Tassara for his work. This seems out of step with Tassara's first letter to Kircher where Tassara praised Favián's many talents, excellent social standing and good family. Likewise, Favián claims that Kircher's crate of books and instruments appeared to have been opened and significant items were missing. It is possible that underpaid couriers could have sought to regain their investments of time and transport costs by selling the contents that they carried. Similarly, port authorities and mule-train thieves could well have removed items at any point during transport as well.

In 1810, once economic concerns under the Bourbon Reforms in New Spain had grown too great in number and too burdensome to tolerate, the historical moment was right: Madrid was invaded by Napoleon's brother Joseph Bonaparte and the Spanish king fled to France. With the crown in disarray, New Spain's colonial elite declared Mexico's independence from Spanish rule. After roughly a decade and a half of battle, novohispanic elites reinvented their government with the 
republican ideals of a criollo and mestizo state using a "symbolic economy that validated creole society" (Restrepo 2014, 85). However, Alexandro Favián's letters reflect no premonitions about the future insurgency of his native Puebla. Instead, they make clear that he hit the equivalent of a glass ceiling: his lack of professional advancement was not uncommon among other locally born sons of the novohispanic elite. Ultimately, the close reading offered here depicts a very human and frequently bemusing attempt, by a cleric with both aesthetic and intellectual inclinations, to obtain a post which he was not permitted to hold, at least in part because he was born and raised in the colonies. No doubt it could be said that the personal was political in seventeenth-century Puebla (Rubial García 2016 p.76). And it was not for lack of trying that Favián failed to achieve his much sought-after bishopric using the tools of the time, namely paperwork, silver bars, and persuasion.

\section{Notes on the Translation}

The area of translation theory concerning scientific works is currently growing. A special issue of Annals of Science from 2016 identified that in the past, translators have failed to acknowledge and discuss in detail various complexities relevant to scientific works, such as the local socio-linguistic communities which coined technical vocabulary (Dietz 2016, 119-120; Rodríguez-Medina 2019). My work, however, aims not only to provide an English version of the letters, but also to focus on Favián's socio-political backdrop, as my annotations provide contextual commentaries on elements of interest to the history of science, an area that has received scant attention by translators and critics. Indeed, such an approach is essential when tackling Favián's letters, as he is a consumer of technical works. Thus, Favián is able to adapt his requests for more of Kircher's books and scientific instruments by identifying precisely where in Kircher's (and sometimes in other authors') writings the items or books are mentioned. This demonstrates Kircher's vast knowledge of a scientific community based in Europe and demonstrates Favián's careful attention to his books.

When translating the collection of letters, I have focused on two aspects. First, to make accessible references to historical figures and early modern book titles. Second, to clarify the formulae and tropes of discourse for the purpose of making accessible the way in which science was advanced and engaged with in these two communities. As discussed later in greater detail, it is with those two aims in mind that I have translated and annotated these letters. More specifically, Favián and Kircher's epistolary friendship poses an interesting case study as it provides insights into the networks of two scientific communities. As such, early modern friendship among long-distance networks of scientific correspondents can be explored within the study of translation theory in so far as participants signaled their epistolary alliances by using a range of rhetorical strategies such as name-dropping, humility tropes, and linguistic intensifiers. These too are elaborated upon in the annotations.

Translation has always had a historical component, particularly when we think about the many cultural aspects that inform the historical document in question. For historian Alison Clark 
Efford, "even when historians do not cross linguistic divides, our work overlaps with that of translators" (2019 n.p.). As explained by Efford when describing her collaboration with a translation scholar, "the skopos of our translation obliges us to consider the fact that historians will be using letters in our book as primary sources. We have to balance the goal of presenting accessible texts against the challenge of reproducing the distinctive style, specific references, and sometimes ambiguity of the originals" (2019 n.p.). Likewise, the translations in this thesis seek to be useful and accessible while preserving some of the authenticity of the source text's cultural milieu. Thus, this study also aligns with cultural translation practices in that it aims at mediating "cultural difference." According to the Encyclopedia of Translation Studies, the concept can be defined as referring to practices that "mediate cultural difference or try to convey extensive cultural background or set out to represent another culture via translation" (2008 p. 67). In doing so, my translation of Favián's letters from Spanish to English involves two distinct sets of translation practices which include the representation of a specific slice of seventeenth-century New Spain, the source text's culture, and its particular use of language.

In “On Linguistic Aspects of Translation,” Roman Jakobson describes three different types of translation: intralingual (within one language, as in rewording or paraphrase); interlingual (between two languages), and intersemiotic (between two different sign systems). Following Jakobson, this study combines interlingual translation, that is translation carried out between two different languages, with intralingual translation. Aligning with interlingual translation, or translation proper, the Spanish letters were translated into English. Furthermore, annotating them constitutes a form of intralingual translation, or exegetic adjustment of the target language (1971 p. 261). Though I have attempted to not "stage an alien reading experience," as Lawrence Venuti has persuasively argued is useful for reminding readers that they are not reading a source text, (1995 p. 20), there are moments when I have sought to keep the tone of Favián's writing or to express the flavor of his time. And while not aiming at entirely domesticating the target text, my translation does aspire to bring the source closer to the target reader.

A translator of historical sources, like a cultural mediator, bridges the distance between linguistic cultures and historical worldviews with, in this case, explanatory annotations (Porter 2013 p.63). Indeed, annotations such as the ones I provide entail discussions of the author's cultural context, which is in turn a space to reflect on the act of translation (Baker 2004 p.182; FrankenbergGarcía 2009 p.7). In this first translation of the letters into English, I strive to make the texts accessible to a twenty-first century audience which means that I sometimes omit the redundancies and excessive humility tropes that are so characteristic of Favián's exuberant, somewhat mystical personality, while at other times when they served to emphasize the tone of his text, I have kept them. Overall, my annotations provide the reader with notes, comments, and explications of Favián's intellectual and cultural milieu, sometimes with a focus on unpacking the meaning of individual words chosen by the author, but more frequently with an eye to explaining historically relevant 
information which, as Baker points out, is one of the key aspects of paratextual features such as annotations (Baker 2018 p.235).

I have used Osorio Romero's transcriptions of Favián's letters as a main source. A Mexican scholar of intellectual history, Osorio Romero identified and transcribed letters from two archives of Kircher's correspondence in Rome, a selection which was posthumously published by UNAM as $L a$ luz imaginaria: epistolario de Atanasio Kircher con los novohispanos (1993) from which I have translated only Favián's missives. Of the forty-three letters by six different authors included in Osorio Romero's compilation, eleven are included here. For further reference, the digital images of many of the letters have been made available online through the Stanford University Libraries as part of the Kircher Correspondence Project (https://stanford.edu/kircher/). The annotations included in the following section could contribute to this project by providing a commentary which examines the context of Favián's letters and presents new ideas about why and in what historical milieu the letters were written. Importantly, the annotations also discuss the challenges of translating a historical work and explore whether translation can cross the divide between centuries of epistolary fashions (Mădălina 2009; Zelechow 1993). In many ways, annotations are the perfect tool for translators and historians as they provide the space for making scholarly explanations commenting on a range of linguistic and grammatical or contextual issues. While I include notes to contextualize and explain some linguistic features including grammar, vocabulary, and expression, my annotations mostly serve to provide the reader with background information on aspects of the history of early modern science and also on certain features of Church History, in addition to the history of colonial Mexico.

Additionally, reading the letters together produces a form of distortion, since they were written and received in 1-to-2-year cycles if the letters arrived rather than being lost, stolen, or confiscated by port and Inquisition officials (Leonard 1971). The constant tension of repetition in the letters conveys a sense that Favián wrote his letters without knowing whether they would arrive or ever be read. Indeed, Kircher's archive shows that he had a secretary or assistant read a few of Favián's letters and then produce a concise summary of the main points presumably to cut down on the time it would take Kircher to read all his extensive correspondence (Fletcher 1969 p.153). Kircher's correspondence archive shows that it was one of the larger ones for his era; he had over 300 distinct correspondents, and the Kircher volumes at the historic archive at the Gregorian Pontifical University in Rome hold 2,292 letters addressed to Kircher (a mere 148 authored by Kircher), which makes the attentiveness which he showed to Favián all the more striking.

Moreover, I propose that in translating letters we need to keep in mind various socio-cultural asymmetries between the author and recipient as we would have in other historical documents. The correspondents employed a form of cultural mediation to overcome such imbalances - of information, social status, assets - inherent in long-distance relationships. During the early modern period the Republic of Letters had a significant impact upon the vitality of the scientific revolution. Historian Anthony Grafton describes the role of the letter as "[constituting] the fragile but vital canals that 
connected and animated intellectual commerce," and as "a capillary system along which information could travel" across Europe (Grafton 2009, p.7). The Favián-Kircher correspondence shows how far beyond Europe this "intellectual commerce" took place and how its inherent asymmetries could be negotiated.

In tackling the translation of the letters into English, a series of issues arose, not only from the point of view of lack of equivalence at word and sentence level (Baker 2018), but also at the level of tone and register. Given that Favián's letters to Kircher were written between 1661 and 1672, my aim was to strike a balance between domestication (producing a translated text so fluent in dominant cultural forms and expressions that readers are unaware that they are reading a translation) and foreignization (an ethical stance whereby the alienness of another culture is made apparent to readers of a translation) as defined by Venuti (1995). In that respect, the process of translation was twofold: first, I did a preliminary translation. Second, once a draft of the English translation was done, I did an intralingual translation to bring the text to a more contemporary version being careful at all times that the essence of the original was not lost but equally that it did not alienate the contemporary target reader. Thus, while readability was the goal, the source text and culture were central when rendering the text into English.

Initially, and in the final editing stage, I sought to use punctuation to break up Favián's lengthy sentences which often take up most of a page. While accessibility was key when rendering the letters, an effort was made to retain the general structure of Favián's style to give the reader a suggestion of his personality while anchoring the text to its milieu. One of the most salient features of the source texts is the use of formulaic expressions for addressing persons in roles of authority and for addressing clergymen, specifically, to signal deference. Letter writing at this time was an artform characterized by the usage of praise and humility tropes. The "artificiality" of the medium ranged from lists of honorific titles, euphemism, figures of speech, exaggeration, and other forms of flattery or insincerity (Vonk 2002). While at times Favián comes across as a fawning supplicant this seems to be a strategy for making requests; he also seems very aware that he is inconveniencing his reader with his many entreaties. Rather than make fewer requests, in order to avoid bothering his reader, he decides to make up for the trouble by way of gifts and payments, but ultimately through his words of praise and adulation. Moreover, Favián was a great fan of Kircher's books which, as he stated more than once, gave him "recreation and rest" from other parts of his life as well as the inspiration to pursue his mechanical hobbies.

As regards the layout, ideally the letters would have both the original and the translation on facing pages, but for practical reasons the Spanish originals are not included. My initial goal has been to make the text readable to a contemporary non-specialist audience, more so than a translation strictly focused on capturing Favián's energetic, yet lengthy, stream of consciousness. I have decided to keep the two-column formatting chosen by Osorio Romero's publisher when they printed his transcriptions of Favián's letters because it renders the rather dense and meandering paragraphs easier 
to read. Another feature introduced in Osorio Romero's edition is that each paragraph is numbered in brackets, and I have maintained these numbers for ease of reference. In Favián's manuscript letters to Kircher, the writing goes all the way across the page as you would expect of a handwritten letter; his use of punctuation is limited primarily to capitalization, semicolons, and, very rarely, the full stop. Given that the letters themselves are long, and sentences are also lengthy and, at times, read as stream of consciousness due to the scarce punctuation, I have retained the paragraph numeration in my English translation to aid the reader.

Finally, translators are charged with the responsibility to render foreign language texts intelligible to contemporary readers. As a cultural broker of sorts, a translator must negotiate the array of potential meanings suggested by the original author for audiences reading in a distinct culture. In light of this, errors and less obvious faults in this translation have been diminished through a process of consultation with experts and language specialists in an attempt to make as accessible as possible the letters of two seventeenth century authors. As collaborative an enterprise as translation is, consulting with experts was a key stage of my research in preparing to translate Favián's letters. I hope my work contributes to show the ways in which the Favián-Kircher correspondence testifies to the "intellectual commerce" between two distant scientific communities by way of their shared networks. 


\section{Part II: An Annotated Translation}

This section includes the annotated translations of letters 1-5, 8, and 10-11. Due to space limitations, I provide summaries of letters 6, 7, and 9, all written by Alexandro Favián to Athanasius Kircher between 1661 and 1672. The layout follows Osorio Romero's by presenting English-language translations of the letters as they appear in La luz imaginaria (1993). For easier reference, paragraphs are numbered in my translation as they are in Osorio Romero's epistolary. A published translation of Favián's epistolary would ideally include other important paratextual features such as the transcriptions, images of the manuscript letters, illustrations, and maps.

\section{List of Alexandro Favián's Letters to Athanasius Kircher in Rome}

First letter: Puebla, 2 February 1661, p.20

Second letter: Puebla, 9 May 1663, p.34

Third letter: Puebla, 23 August 1664, p.51

Fourth letter: Puebla, December 1665 / January 1666, p.55

Fifth letter: Puebla, 10 March 1666, p.66

Sixth Letter: Puebla, 12 March 1666 (Summarized), p. 74

Seventh Letter: Puebla, n.d. March 1666 (Summarized), p.77

Eighth Letter: Puebla, 2 August 1666, p. 78

Ninth Letter: Puebla, 20 April 1667 (Summarized), p. 85

Tenth Letter: Puebla, 14 November 1667, p. 85

Eleventh Letter: Puebla, 20 April 1672, p. 95 


\section{Letter 1}

To Father Athanasius Kircher

[1] The light that is not beneath a bushel but upon the candelabra cannot help but spread its rays to all places; and much more so when it is so high up as Rome, which is no less than the head of Christianity, and its resplendent rays are so extensive that both within Rome and throughout the other parts of the world, this light has spread the admirable wisdom that the Divine Majesty of God, Our Lord, deigned to grant Your Reverence and which has arrived already in these parts of the world: New Spain and the Indies. Inspiring the genius of its scholars with such recondite and rare and admirable writings that not only have they caused admiration but astonishment - at least to me. My astonishment was of such a degree when Father Ximénez, who was the rector of this Colegio del Espíritu Santo, ${ }^{1}$ told me of the books which Your Reverence had sent him and showed me the catalog of the other books which you had published as well as your forthcoming titles. Of which I say, truly, absque exageratione $^{2}$ that in my life, I have not had a more admirable ${ }^{3}$ experience.

[2] It just so happens that I was raised $a b$ incunabilis $^{4}$ by the Jesuit Order, and that my family's homes are so closely tied to the said Colegio del Espíritu Santo, about which I often boast that I may well be said to have lived within it or that I should be a member of the order. ${ }^{5}$ And so, where the liberal arts $^{6}$ are so frequently practiced, it is a given that I would

\footnotetext{
${ }^{1}$ The Colegio del Espíritu Santo in Puebla de los Ángeles was founded as a Jesuit educational institution circa 1590 and is today the site of the distinguished Biblioteca Histórica José María Lafragua.

2 "Without exaggeration." Latin phrases were commonly used by educated people and were especially pertinent to ecclesiastical discourse. For these reasons the Latin has been retained to establish the tone of the source text; translations of the Latin phrases into English are annotated.

${ }^{3}$ Favián was prone to hyperbole. Another recurrent stylistic feature of his is reiterating his feelings by using two, three, or four near synonyms that emphasize his esteem for Kircher.

4 "From the cradle."

${ }^{5}$ It is unclear why, as a priest, Favián did not simply join the Jesuit order, or perhaps one of the other religious orders in his hometown; perhaps he did not pass the Jesuit order's stringent requirements. Athanasius Kircher himself failed the first time that he applied to join the Jesuits (Godwin 1979, 10). Closer to Favián in New Spain, Carlos Sigüenza y Góngora (1645-1700) is another example of the stringency of the order: he was expelled from the Jesuit house in Mexico City and denied re-entry on account of youthful disobedience. Alternatively, it is possible that Favián arrived at his clerical vocation during a period when his family needed him to manage their properties and inheritance; this may have disqualified him from joining a religious order where finances would have been collectivized. The demands of Favián's intellect, however, may well have been satisfied had he joined an order: the collective resources of a religious community with its dormitories, sacerdotal work, routines, mandated social interactions, and most significantly for a science hobbyist such as Favián, a rich library collection would have suited him well. By the end of his twelve years of letter writing, he had missed out on the reliable workplace, housing, and income that he might have otherwise experienced had he chosen to live within an established religious order.

${ }^{6}$ Favián uses the term "las letras" here to refer to a category of studies which are a contrast to mathematical studies, but my translation is a conscious approximation. A more precise rendering would be "the studies of the trivium" (grammar, logic, and rhetoric) with the addition of Spanish philology and theology, as opposed to the quadrivium (arithmetic, geometry, music, and astronomy)
} 
learn something cum electo, electus, eris, etc. ${ }^{7}$ But more so than I did with these studies, I have dedicated myself with special care to mathematics because of the particular propensity of my nature. Additionally, as there are few or no authors of these books on the science of mathematics ${ }^{8}$ here, fewer still those who publish them, nor do books about these forms of knowledge arrive among the imported books, even though many other imported texts arrive; we lack, entirely, the true understanding of the science of mathematics because we do not have the texts to study them with. ${ }^{9}$ And now take for example, in the musical domain, the lyre, an instrument about which we could say that in these realms, that it had not only not been seen before but also, that no one would have known what it was for. ${ }^{10}$ Then desiring to build one based upon what I had read in humanist writings ${ }^{11}$ about lyres in the ancient authors, it was not possible to achieve its composition and shape precisely for lack of sufficient information about lyres, more so, without having seen one in person and not being able to find anyone who could build it. Needless to say, it is likely impossible to find any books specifically about these instruments, or there is likely no author around to explain and elaborate upon those books which might be available. I continued in my experiment to complete the construction of one, attaching the strings and making adjustments to make it good in so far as harmonic consonance is concerned. However, I could not know how it would compare with the ones that are built in Europe, which are exact, until hearing that the admirable book authored

which comprise the topics that Favián expresses interest in throughout his letters to Kircher. The trivium and quadrivium made up the seven liberal arts which were the standard curriculum in Catholic educational institutions from the Middle Ages on.

${ }^{7}$ Among other topics, Favián is well versed in biblical references from which he often quotes as he does here: "You show yourself pure to those who are pure and unfriendly to those who are crooked," (2 Samuel 22:27).

${ }^{8}$ Favián uses the word "ciencia" in this sentence without qualifications and seems to mean at least two different concepts: the common early modern usage to mean "knowledge or learning" and a specifically more mathematical and creative, or exploratory, form of learning which Kircher engaged in in his own works.

${ }^{9}$ Here Favián signals his enthusiasm for mathematics, but his comments about the absence of mathematics texts and of local authors of these books should not be taken as fact. His mathematical curiosity certainly demanded more than the applied mathematics texts that circulated in Mexico City during the seventeenth century, but what he is doing in this paragraph is building a case for why Kircher should feel good about sending him new books. On the mathematicians of sixteenth, seventeenth, and eighteenth-century Mexico, their publications and their scientific book collections see Elias Trabulse's works especially his Historia de la ciencia en México: siglo XVII (1983); also see Burdick, 2009.

${ }^{10}$ When writing to Kircher about Favián's family in 1664, the Genoese courier, Francisco María Tassara described Favián as a talented musician who played a range of rare stringed instruments (Osorio Romero 1993 p.43). This explains Favián's particular interest in Kircher's work about music the Musurgia universalis (1650), and Kircher's ideas in this work, about the nature of the universe as a harmony of all forms of knowledge, including divine knowledge, hints at Favián's sometimes rapturous experience of reading his works.

${ }^{11}$ Here Favián refers to the works by humanists (i.e., frequently taught classical or Renaissance authors): "lo que había leído de las humanidades." 
by Your Reverence, Musurgia ${ }^{12}$ had arrived in this realm. There I saw that the one I had built is in accordance with all that Your Reverence explains. This is one of the reasons for my admiration. The other is having in my possession an instrument which someone has brought from Aspurg, ${ }^{13}$ built by Samuel Biederman. It plays itself, three different musical tunes, by way of the movement of gears held within a box containing 17 strings, and these also work the nine dancers that move in synchrony using more gears. I had disassembled it and rearranged it; and although neither I nor anyone in these lands had ever seen it before, I put it into order and reassembled it, leaving it functional, adjusted, and in tune. This was a feat of admiration here. Because I had such a difficult time of it, I was able to recognize the art and science ${ }^{14}$ involved in such an object: I imagined that it was not possible for there not to be something written, or at least noted in brief, about an item of such genius and beauty.

[4] It was during this period, that I had a dream about an admirable book where there was not only a description of the aforementioned musical instrument, ${ }^{15}$ but where I also saw an image of it painted in color, ${ }^{16}$ upon the pages of the book. This dream took place shortly before

${ }^{12}$ The first edition of Kircher's Musurgia universalis, sive artis magna consoni et dissoni (1650) was published in Rome and dedicated to Archduke Leopold Wilhelm of Austria (1614-1662). The work explores a theoretical relationship between dissonance and harmony and forms a kind of triptych of ideas explored in Kircher's works on light and magnetism. Favián would have had access to this book at the library of the Jesuit College in Puebla where he was a confessor to the priests and where he met the French, Jesuit priest Francisco Ximénez who was instrumental in establishing Favián's correspondence with Kircher. Ximénez wrote to Kircher in 1661 to introduce Favián calling him "my friend," and a "virtuous priest and a lover of good books" (Osorio Romero 1993 p.18).

${ }^{13}$ Favián appears to have meant "Augsburgo" (Augsburg, Germany).

${ }^{14}$ Favián's designation here, "arte y ciencia," feels very modern. It also signals his interests in the overlap between these two distinct areas of learning that is evident throughout his epistolary communications with Kircher.

${ }^{15}$ Samuel Biedermann the Elder of Augsburg became known for his self-playing organs circa 1600, so the object is likely to have been a form of music box or an early keyboard (i.e., virginal). This "instrumento artificioso" might also have possibly been an elaborate clock. Augsburg is in the region of Bavaria which became famous for its intricate clockworks starting in the first quarter of the 1600s, and Kircher did describe a wonderful timekeeping device (i.e., the Black Forest cuckoo clock) from Bavaria in his work on music, the Musurgia universalis, but Favián does not specifically mention a time-telling function here. Also worth noting is that by 1669, a Tuscan by the name of Domenico Martinelli, a priest and architect who had travelled widely in Europe, published Horologi elementari which explained the workings of geared clocks. It is not likely that Favián would have known about Martinelli's forthcoming book, but there may have been a network of Italian priests discussing the new clock designs from Bavaria in their letters, and in turn, communicating with overseas correspondence networks. This signals the extent to which knowledge circulated at the time and Favián's position as a Novohispano man of science. It is remarkable that he was familiar with the latest arts and sciences of his time even without being a member of the Jesuit order.

${ }^{16}$ Two of Favián's copies of Kircher's works, today kept at the Biblioteca Palafoxiana in Puebla, have a manuscript dedication from Kircher to Favián and include hand-colored images. The hand-colored illustrations are applied on some pages with more skill than on others, as if the aspiring artist sometimes had difficulty controlling the watery pigments. Based on the images selected for coloring, whoever did the hand coloring must have read Favián's letters, or perhaps it was Favián himself. 
I ran into Father Francisco Ximénez on my way to the Church of the Colegio del Espíritu Santo to give a mass. He gave me notice of the books, (as he normally does because he is a good friend) which Your Reverence had sent him. And the very first which he placed in my hands was the one which I had dreamt about: ${ }^{17}$ the Musurgia universalis. Your Reverence should consider whether if through one or another cause my great and well-deserved admiration is not justified. More than any other of the books which Your Reverence has composed, the topics and themes in this one have seemed to me, best suited to and very much in accord with my interests. So much so that it could be imagined that Your Reverence is able to read my thoughts even from so great a distance. ${ }^{18}$
[5] All these reasons and others still explain why I boldly requested of Father Ximénez, trusting in the great kindnesses that he regularly shows me as my great patron, ${ }^{19}$ that he would write a letter to Your Reverence asking if it would be possible that I might be so fortunate as to have you send your writings despite the trouble and inconvenience of sending them all together. That way those which have already been printed and those which were about to be printed, if they have been now, can arrive here in this kingdom ${ }^{20}$ in response to the humble requests of their aficionados and devotees. And, that we aficionados may deserve this good fortune which to me, truly, would be so great that I cannot imagine wanting anything else in this life if I were to achieve this. ${ }^{21}$ Moreover, since we do not know how much these many volumes may cost in Rome, in order to give the

\footnotetext{
${ }^{17}$ Favián lends his account a touch of divine providence by way of a dream. Both he and Kircher would have been familiar with the motif from Biblical stories where God communicates through a dream; saints' stories, with which Favián shows a great familiarity in his letters, likewise include providential dreams. Kircher's Iter extaticum (1556), which includes a central dream sequence, became very influential in the literary works of colonial Mexico; Sor Juana Inés de la Cruz's poem "Primero sueño" makes clear reference to this work of Kircher's.

${ }^{18}$ Phrases like this one may have persuaded historian Paula Findlen that Favián desired to make himself "the American Kircher" (2004, 340). My own reading is slightly different: Favián saw Kircher as potentially filling many roles for him, in particular that of a well-placed mentor, patron and advocate.

${ }^{19}$ Like a Don Quixote figure, Favián's words sound slightly old fashioned even for his time, he describes Ximénez as, "tan señor mío," as if they were in a feudal relationship. (Cervantes' work was widely distributed in Spanish America in the early 1600s as demonstrated by Leonard Irving (1964, 271).) Favián uses these same lord-vassal tropes when addressing Kircher throughout the letters. He may believe that these figures of speech will identify him as a true fan of Kircher's work and make Kircher willing to respond with generosity; as such, Favián comes across here as a humble supplicant of a powerful, feudal lord. This fawning tone lessens in later letters, changing according to perhaps his sense of urgency or insecurity over the gifts and payments that he sends across the Atlantic and via unsafe overland routes.

${ }^{20}$ Favián uses the word "reino" which is the historically accurate term for New Spain and the other Spanish colonies. "Colonies" is, despite its frequent usage today in reference to the Spanish territories in the Americas, not the nomenclature used at the time (Bleichmar 2009).

${ }^{21}$ Favián will continue to ask for the complete set of Kircher's publications in coming letters, and as if spurred by the dissatisfaction of an incomplete book collection, he will feel entitled to request other more difficult favors of Kircher over time.
} 
amount of money that would accrue for the books as well as the shipping, Father Ximénez and I have been uncertain ${ }^{22}$ and we have speculated about it on various occasions until we settled on sending Your Reverence 150 pesos in units of reales ${ }^{23}$ and Your Reverence would adjust the prices of each and for the fees charged between there and their arrival here. If by chance, there is any money left, Your Reverence might purchase for us a few things in Europe that are highly valued here and which I need very much.

[6] And so for this reason it seemed to me appropriate to send Your Reverence 250 pesos en reales de a ocho ${ }^{24}$ with my humble request, although I have not been of service to you, ${ }^{25}$ that you do me the honor and favor of this solicitation. I pray and hope that through Our Lord, my message may have a successful reception by Your Reverence, whom even without ever having seen you in person, I esteem as an oracle of the sciences, and regard with the love of a son for his father, ${ }^{26}$ so that all your works will arrive here in this land, and principally those which the catalog note in your books says non reperiri amplius ${ }^{27}$ which are the Primitiae gnomicae catoptricae [1635] and the Specula melitensis [1637] because they are greatly desired, and which will no doubt be found so long as Your Reverence wills that I may have them. Also, the Mundus subterraneus [1665] divided in ten books and the Ars magna quam combinatoriam appellamus [1669] which is one of those that we $\mathrm{e}^{28}$ most long to see with the said annotations, and above all else, the

${ }^{22}$ This topic of needing to calculate the costs of transport recurs in the letters and may have created hard feelings between Favián and Kircher and, also, between Favián and Francisco María Tassara, the man to whom Favián entrusts most of his deliveries.

${ }^{23}$ The peso would have been a "piece of eight" and a real was one eighth of a peso. For the value of this quantity see: Hamilton, 1934.

${ }^{24}$ This is the so-called "Spanish dollar" which, in the year 1800, contained a standard 25,560 grains of silver; due to runaway inflation in Spain during the final quarter of the seventeenth century and well into the eighteenth century, its actual purchasing power would have been greater in the fifteenth and sixteenth centuries.

${ }^{25}$ Despite his fastidious requests in future letters, Favián appears to genuinely desire to be of service to Kircher. He shows this by, later, sending a rare seashell for Kircher to include in his next publication, special drinking chocolate that will give Kircher and other distinguished members of the Jesuit order strength during the Lenten season of fasting, and a difficult-to-source feather portrait made by indigenous artists in Michoacán.

${ }^{26}$ Favián holds Kircher in highest regard, writing: "[lo] estimo como a oráculo de las ciencias y amo como a padre." This regard for Kircher as a father figure is repeated and emphasized in later letters. The words may come from a genuine desire to share his thoughts with someone who has his best interests at heart after the death of Favián's father, Alejandro Fabiano. Based on documents archived at the Archivo Municipal Histórico de Puebla, Favián's mother was a widow by 1655 (ficha 14298 vol.0023 doc.121) and the last petition filed by Favián's father, who was owed money by the city council, was from 1652 (ficha 14274 vol. 0023 doc.114). Favián would have been not quite thirty years old when his father passed away.

27 "Will not be found anymore."

${ }^{28}$ Favián's use of the first-person plural may be a way of softening the demands of his requests by suggesting that he represents the wishes of a group of peers and friends, mostly clergymen, as mentioned by Favián in later letters, or it might be a reference to Ximénez as mentioned in previous paragraphs. It is also possible that he was being intentionally ambiguous in order to keep his plans 
Musurgia universalis [1650]. ${ }^{29}$ Finally, I implore and entreat Your Reverence that, by the Love of God, none of the books are left out because the absence of any one of them will be sorely missed. And if they could come already bound, because here there is no one who will know quite how to trim the printed text blocks as they deserve to be or with the precision that is required. That is the reason why Father Francisco Ximénez has not wanted to have the books, which Your Reverence sent him, bound. He says that he prefers to keep the books as they are than for them to be given a second-rate binding. ${ }^{30}$

[7] Additionally, if Your Reverence would do me the favor of ordering two or three sets of twelve, small format breviaries of one month each, which I have heard are available there, as well as two missals. If possible, all of these should be for the saints of the Order of Francis. Also, a half dozen prayer books containing the Divine Office for the week of Corpus Christi. But what I most entreat Your Reverence for are, if they are available, books about the art and composition of clocks with gears because the art of these machines is a source of such diversion and interest that I have given myself over to it in wholesome entertainment learning to work them and repair them on my own, without any instructor, because here, in this land, there is no one who would know or understand anything about it. ${ }^{31}$ And so, I have greatly desired to hear about any author who

flexible. In a later letter Ximénez becomes upset with Favián for allegedly not giving him the books which Kircher had sent; Favián responds by dismissing Ximénez's complaint explaining that the circumstances of Ximénez's promotion to the Mexico City as official confessor to the viceroy had made him very difficult to reach. Favián may have earned Ximénez's damning words for what appears to have been an annoying, if relatively minor, inability to deliver books as promised. ${ }^{29}$ Starting with the Primitiae gnomicae, the book titles indicate their contents: on sundials and mirrors; on an observatory or mechanical calculator of astronomical positions built by Kircher in Malta; on geological and geographic investigations; on the "combinatory art" of examining varied forms of knowledge; and on the relationships between musical harmonies and the proportions of the universe.

${ }^{30}$ Favián actually says that Ximénez fears that the local bookbinders will ruin the books: "que les hechan a perder." Favián's fastidiousness on this point appears to have originated in the views of Ximénez, an old acquaintance of Kircher's from the days when they were both at a Jesuit college in Lyon, France (Osorio Romero, Introducción p.xvi). Ximénez's harsh take on the skills of locals comes up again as a generalized dislike for the character of people from the Americas. Ximénez was not alone in thinking that persons who were born or raised in the Americas, even the children of Europeans (i.e., criollos), were flawed and lacked key virtues. (On this prejudice against those born in the Americas see Cañizares 2006, 73-79 and More, 2012, 40.) A few years later, Ximénez turns on Favián and writes to Kircher to discourage him from replying to any more of Favián's letters. Ximénez describes Favián using the tropes of this well studied "degenerate creole" discourse.

${ }^{31}$ Favián seems simultaneously to be alert to the intellectual trends in the non-Protestant regions of Europe and to be unaware of, or avoiding, his mathematically minded peers and seniors in Mexico City. For example, the Mercedarian friar, Diego Rodríguez (1598-1668) who had just turned sixty years old at the time that Favián wrote this letter, might have been an ideal "maestro" for the younger engineering hobbyist. Fray Rodríguez joined a monastery with an excellent, royally endowed, library and became professor of Mathematics and Astronomy at the Real Universidad de México in the decades immediately before Sigüenza y Góngora filled the same position. Fray Rodríguez used his east-facing monastic cell as an observatory and was in epistolary communications with the 
has written about this art, of which I suppose there must be many, or at least one who specifically explains the way in which they are built and maintained, the number of teeth that each gear ought to have according to its size, the positioning and direction which the movement of the gears require and whatever else is pertinent to this which I am certain that Your Reverence will not be without full news of. I at least, do not have $\mathrm{it}^{32}$ and am certain that no one here does unless it is an author who wrote in
Tuscan, but that work is not available. ${ }^{33}$ And so, it is for this that I plead, in particular, that Your Reverence will purchase and send any books, alongside your own books, which might be available concerning these matters, regardless of the language. Latin and Castilian texts are best because I am not as skillful in the other languages. Also, a current ephemeris ${ }^{34}$ by an author of Your Reverence's choice because the ones that I have are all out of date and I do not expect to find any here. ${ }^{35}$

mathematician Jesuit Claude François Milliet Dechales (1621-1678) in Lyon. Fray Rodríguez also produced at least seven unpublished manuscripts on mathematics and astronomy including one on clocks, Tratado del modo de fabricar reloxes (1638) and led a scientific discussion group - a contertulia composed of educated, criollos where Favián would have fit in nicely (Trabulse 1985, 15). ${ }^{32}$ Favián appears to be referring to both the news of the book and to the book itself. On the matter of not knowing any authors of works about geared clocks, it seems that he does know of one written in Tuscan but has not been able to find a copy. This part of the letter raises the question of whether Favián had access to a variety of the conventual libraries in Puebla and which private collections he may have relied upon to indulge his intellect. In his letters, Favián never describes visits to Mexico City, so it seems that he was without access to the major book collections that existed there during the seventeenth century. (Regarding book collections in seventeenth century Mexico City there are a great number of publications, some of which have been published by the Instituto de Estudios

Bibliográficos, UNAM. Also see the classic, Libros y libreros en el siglo XVI by Francisco Fernández del Castillo (1982). The publications by Idalia García and Marina Garone Gravier reflect recent trends in scholarship. On the transatlantic circulation of books see: Pedro Rueda Ramírez, Nora Edith Jiménez, and Carlos Alberto González Sánchez's publications. Also, Ken Ward's PhD dissertation at the University of Texas, Austin (2013) and Irving Leonard's Baroque Times in Old Mexico (1960) are accessible overviews on the topic of book collectors and collections in Mexico City.)

${ }^{33}$ It would be interesting to know whether there was a network of Tuscan clockwork manual authors; if so, perhaps they would have taken part in the seventeenth-century accademia culture whose participants published significant works in emergent technologies such as telescopy and microscopy. Luigi Guerrini's “The 'Accademia dei Lincei' and the New World" (2008) focuses on one such accademia in Rome and offers insights about the networks of well-travelled scholars who made use of their publications.

${ }^{34}$ A genre of publication of astronomical tables somewhat like an almanac. Favián seems interested, here, in ephemerides printed in Europe as opposed to those produced locally. One of the "outdated" ephemerides from Europe which Favián may well have had access to would likely have been printed in Spain, and as such might have been the Ephemerides generales de los movimientos de los cielos por doze años, desde el de MDCVII hasta el de MDCXVIII, authored by Francisco Suárez de Arguello and printed by the soon-to-be famous bookseller of Cervantes' Don Quijote, Juan de la Cuesta, in Madrid. There are currently more than twenty extant copies in historic libraries of Europe and an original edition of this particular text can also be found at the Biblioteca Nacional de México. See: Iberian Books Catalog at the University College Dublin http://n2t.net/ark:/87925/drs1.iberian.25580 Also see: Catálogo Colectivo de Fondos Antiguos entry for this title at the Biblioteca Nacional de México https://catalogo.iib.unam.mx/F/-/?func=find-b-0\&local_base=BNM.

${ }^{35}$ The Catálogo Colectivo de Impresos Latinoamericanos (CCILA) hosted by the University of California, Riverside http://ccila.ucr.edu/, shows its first entries of books entitled "ephemerides" 
[8] I have one more supplication to make, Your Reverence, about which I hope, through the love of God, you will be patient with me because the delays of distance where we are do not permit me to write as frequently as I would like; and, truly, coram Deo, ${ }^{36}$ there is no other person than Your Reverence whom I would like to see, get to know, and communicate with more. And at the very least, I will, when the fleet from Spain arrives in these kingdoms, if Your Reverence gives me permission. ${ }^{37}$ But now I have become distracted from what I was going to say: it was about having, as I mentioned above, a harpsichord that plays itself by way of gears and moving parts which it has within its frame and that is made from a black wood which is curiously carved. The instrument has a very polished body with mechanical dancers on top and is made in Aspurg by Samuel Biederman.BBe It is an object which, as I have mentioned, had never been seen in these kingdoms before and has inspired great admiration. After seeing what Your Reverence explains and demonstrates in the illustrations ${ }^{38}$ we have come to know about

produced in the Americas in the year 1700. (Other alternative titles for works in this genre included "lunario," "pronóstico," "almanacque," "cometa," "metheoros," or specific planets such as "Saturno.") But there would have been at least some local astronomers' publications printed in New Spain for the seventeenth century, such as the many pamphlets discussed by Carlos Sigüenza y Góngora in Libra astronómica y filosófica (1690) regarding the astronomical debates concerning the comet of 1680. Pamphlets are likely to have fallen through the gaps in the historical record, although Burdick includes Alejo García's Kalendario perpetuo among the ephemerides printed as early as c.1575 in Mexico City (p.184). If Favián is referring to Puebla specifically, then his comment might have been accurate.

36 "In the presence of God." Within the context of Favián's letters, his frequent invocations of God as a witness to the truth of his sentiments sound more like the pious enthusiasm of a bygone era than sacrilege. In this modernized translation, the phrases could easily be misread as sarcasm.

${ }^{37}$ It seems that Favián has caught himself rambling. This seems to be one of the points in the text where Favián sets his letter down and picks it up again later, or perhaps the next day, when he had a new topic in mind.

${ }^{38}$ The illustrations in Kircher's books are indeed curious combinations of visual codes: they contain technical drawings decorated with symbolic and esoteric items and were printed from a relatively new technology, carved copperplate which allowed for finer, more precise images than woodcuts. It is interesting to note that Favián limits his praise and interest to the applied and empirical aspects of Kircher's works. He never once mentions Kircher's grand, holistic explanations of how complex and varied aspects of human experience can make sense of a universe made by a biblical God. It is possible that being, at times, a pragmatic person, Favián wanted to avoid any type of censure and the accompanying delay if the letters were read by Inquisition officials at the ports. Or perhaps the specifically hermetic nature of Kircher's works did not register for Favián as a topic requiring discussion. Osorio Romero remarks in his introduction to La luz imaginaria that Favián is a complex figure, and in the historian's words Favián is "la metáfora barroca en apogeo." Osorio Romero also wonders whether Favián was "¿un místico? ¿un hombre de ciencia? ¿un frívolo amante del poder?" (p.xix). I suggest that Favián's letters show that in some crucial ways, he had a very modern approach to career advancement in so far as he sought to strengthen his social standing through his professional networks. He was clearly making the most of his acquaintances, (see Granoveter's influential study, "The Strength of Weak Ties," 1973), and hoped to land a sinecure by demonstrating his worthiness. Based on his own descriptions of his emotional states, Favián also seems to have suffered from the very modern affliction of anxiety. The letters are a snapshot of a decade when his financial insecurities made him a difficult person to stay friends with, and yet it may have been his productivity 
and have understood things of great ingenuity that are worthy of even more admiration, as are, truly, the instruments which Your Reverence has brought to light. Many instruments were unknown here, principally, the self-playing organs such as the clavichord with gears. And so, I ask and pray that Your Reverence will do me the kindness of letting me know how much one of these little "artificial" organs would cost - not the kind that runs on water but rather the ones that move with gears in the same manner that table clocks do. And if it were like those that Your Reverence shows in figure XXII, volume 2, page 347 , that has the blacksmiths on one side and on the other side, some dancers and a figurine of Death. Or, as it is in figure XXI, volume 2, page 343, which has a rooster or a bird on top, if, that is, they come already attached and have already been made as they are depicted by the illustrations of your book. If you would advise me about the cost of these, so that on the next fleet I can send Your Reverence the amount in reales.

[9] Or it would be much better if the 250 pesos that I am sending Your Reverence paid for the books, which are essential, and whatever else may be necessary for them. If any of that original amount were sufficient to pay for it, ${ }^{39} \mathrm{I}$ would be very grateful to Your Reverence if you would do me the favor of having the item purchased. The reason being that it is one of the things that I have most desired, and the other that it would be convenient for it to arrive along with the books which, on this occasion, would be very simple to arrange due to the travels of my Genoese correspondent. Genoa, from whence all the Alexanders, Columbuses, and Justinians of my generation have come $!^{40} \mathrm{He}$ is currently in Spain but is due to arrive here in the Indies on the next fleet, which should be in the year 1662 or 1663 . He would bring all the items himself.

[10] In this case, what I most request of Your Reverence is that the said organito, should include, if possible, a clock which is united and conjoined with the movement of the musical gears as well, so that music plays at convenient times and would be set on the clock in the same manner as those of alarm clocks which use bells, because that way it will suit its purpose. This kind of mechanism was recently brought

as a cleric aspiring to be a patron of his community's intellectual and religious practices that was the source of his financial insecurities. He was, alas, in a catch twenty-two situation: flaunting his merits made him subject to envy and criticism for presuming to be worthy of a post, which was at that time, held only for those appointed in Europe. Not being born in or located in Europe set a cap on his professional advancement.

${ }^{39}$ Favián uses a direct object pronoun "lo" which here would be the equivalent of "it," and in this context he seems to be referring specifically to the clavichord which he described immediately before. 40 "De donde es toda mi generación de Alexandros, Colones y Justinianos." These are powerful and famous historical figures whom Favián identifies with through his father's birthplace in Genoa. It also seems to be high praise for Favián's Genoese courier, Francisco María Tassara. Favián's successful brother-in-law, who owns a sugar refining plant, is a Colón and comes from a Genoese family as well. 
to Mexico City, ${ }^{41}$ in which, outside the mechanical organ, there is a low clavicymbalum; sometimes one of them plays and at other times the other does. They are both linked with the clock in such a way and an indice $^{42}$ which comes out of it at midnight or at whichever time one desires it to play its music. It does this according to its adjustments which make the clock run and, also, stop the clock from working. Winding the movement of the musical gears, it fills the bellows, and it also plays if you were to let them go with your hands. Also, it seems to me that the mechanism could be built to have the keys uncovered as they are in ordinary organs, but in such a way that if anyone touched them, they could play the organ with the movement of the hands. The internal parts of the self-playing organ would release in order to play the notes of the musician. Also, it would follow that a person who did not know how to play would be able to make it seem as though he were performing the well-played piece and that he had learned it suddenly or in very little time. Your Reverence knows more about such things than do I, which is why I ask again, enthusiastically, that you do me this favor which I have already mentioned and that Your Reverence will choose whatever you judge to be best to purchase for me through Your Reverence's kindness. And, as I have said already, the other things ${ }^{43}$ can be left out if the money were insufficient to pay for them all.

[11] The good fortune that Our Lord granted me to find out about Your Reverence, and later the occasion for which to write to you, to communicate with you in this way since I cannot speak to you in person which would be the most estimable experience for me in this life, makes me so tedious and bothersome. Someone who has known you and spoken with Your Reverence many times is the person who gave me notice of you, Father Francisco Ximénez. He showed me the printed illustrations ${ }^{44}$ from your books which he had brought from there, such numerous and agreeable places. Our Lord, God gave Your Reverence so many and such singular intellectual gifts, that truly, as I have judged and have said as much, more than once, in conversations with learned men in these parts. How fortunate are those who live where they can interact and communicate with Your Reverence and how happy are we to have such

\footnotetext{
${ }^{41}$ Unfortunately, Favián does not tell us how he knows about the recent delivery to Mexico City; however, within Puebla he seems socially well-connected and also has five adult siblings who could have easily shared their news with him.

42 "Indice" appears to be a word for a specific piece of the cuckoo clock.

${ }^{43}$ Favián's "las otras cosas" seems intentionally ambiguous; earlier he wrote that the books were the most important items to be purchased but here it seems that the musical-clock device is his priority. Kircher must have sensed Favián's unstated desire that some of the items be gifts and thereby make Favián's money stretch to cover the books as well as the musical devices.

${ }^{44}$ For this period, the term "estampas" usually refers to the images or titlepages produced for printed books, often from a woodcut or copperplate. In this sentence it could refer instead to the printed books themselves, as in the word "imprints."
} 
a rare and admirable talent as yours in this century. ${ }^{45}$

[12] The many curiosities and unique, ingenious objects which Your Reverence has made ${ }^{46}$ have inspired in me great admiration. Among these objects, the mirrors which show an object distinct from that which is placed in front of it, so that instead of what should be shown there is the head of an ass ${ }^{47}$ and other figures which catoptromancy shows. Your Reverence has written about long-distance eyepieces which reveal distant and minute objects otherwise imperceptible to the human eye. ${ }^{48}$ Reading what Your Reverence has written in Scrutinio-phisico de peste $[1658]^{49}$ which Father Francisco Ximénez shared with me confirms the truth of these magnifying lenses. These are things which have never been seen in this part of the world and I believe would not be understood. In all these kingdoms one would not find a single person who knows about such things because people who are born here do not apply themselves to studying them. ${ }^{50}$ And this, I believe, must be the reason why books about these sciences are not brought here. ${ }^{51}$ As good as the books may be, they will not sell. This is how it seems to me from the experience of having found some of the scientific books which I own in the forgotten corners of bookstores as if they were useless and unwanted. Some of them were forty years old, and one of the booksellers thanked God that after so many years there might be someone who would buy them in order to learn something from them. ${ }^{52}$

[13] By contrast you have me, a rare individual for the enthusiasm with which I give myself over to these studies. In all truth, temperament aside, it is a greater pleasure to lock myself up in the library or to be occupied with my latest handiwork than the greatest diversions and worldly entertainments. Seeking to be occupied

\footnotetext{
${ }^{45}$ Favián's praise sometimes sounds false; this is one of the points where a reader might cynically wonder whether he was consciously attempting to manipulate Kircher.

${ }^{46}$ Favián requests more information on the assumption that Kircher builds all the objects that are described in his works. This was certainly true to an extent, but Kircher would also have had to rely upon what he read or heard from others or speculated about based on what he understood to be comparable experiences. There are also moments in Kircher's texts where the objects he describes appear, to a twenty-first century reader, to be based on imagination and whimsy.

47 This appears to be a self-deprecating joke: the "cabeza de asno" may well be Favián's reflection in a mirror. Captromancy was a set of mirror tricks and was among Kircher's toolkit of entertaining displays of science and "magic" which he had used in to amaze the patrons of his earlier decades.

${ }^{48}$ This seems to be an early form of binoculars.

${ }^{49}$ In this work, Kircher claims to have seen microorganisms present in the blood of a plague victim using a microscope. He thereafter promoted hygiene measures to prevent the spread of the illness. ${ }^{50}$ In what appears to be an example of anacoluthon, Favián writes: "los naturales dellas ["estos reinos"] son poco estudiosos." This comment may suggest a general feature of socioeconomics: in seventeenth-century New Spain, few educated individuals handled tools or engaged in manual tasks even for the sake of experimentation, in part because of class expectations.

${ }^{51}$ Favián may mean Puebla, specifically, as contrasted with Mexico City in his use of "por acá."

Alternatively, he might be generalizing about the Spanish Americas.

${ }^{52}$ It is notable that Favián is concerned about the possibility of works on science becoming outdated.
} 
in this way and fleeing the many snares and occasions to sin as those that befall a priest who roams the streets and squares. Deus scit quod non mentior ${ }^{53}$ as I do my best to be viribus et posse $^{54}$ in all matters and in my actions because it is only the pleasure of Our Lord, God, that I have always sought. And so it is through the same Lord that I ask Your Reverence to not deny me your favor in my supplications; even the remainders of the many gifts with which the Divine Majesty chose to enrich Your Reverence can assist my worthy aspirations and help me with all that I have entreated so that I may become a disciple of such a great teacher. ${ }^{55}$ In addition, one or two lenses ${ }^{56}$ which Your Reverence describes in your book as permitting sight from great distances and also a mirror that displays varied images. If it were possible for the images to be skulls or death, ${ }^{57}$ that would suit my purposes best; it would be what I esteem most, and what I am most grateful to receive from Your Paternity. And the maps and imprints of saints' and hermits' images as well as any curiosities which Your Reverence chooses. ${ }^{58}$ And if there is no self-playing organ, though I have hope in the Lord that there will be, nor any of the other objects that I have petitioned Your Reverence for, please do me the favor of sending other curious items relevant to the mathematical sciences, such as the celestial and terrestrial globes or a clock which has alongside the hours, an astrolabe and zodiac as described by Joan Baptista Benedicto [1530-1590], a philosopher from Venice, in the book entitled Diversarum expeculationum mathematicarum et phisicarum [1585], on page

\footnotetext{
53 "God knows that I do not lie."

54 "To be strong and capable."

55 This is an interesting proposal: Favián will "qued[ar] yo discípulo de tan gran maestro," if Kircher sends him Kircher's publications along with other items (additional books, a musical clock device, special mirrors, and magnifying lenses) for 250 pesos worth of minted silver coins. Favián comes across as a person who thinks about interpersonal relationships in terms of exchange and implicit contracts although, as his concerns about retirement betray in later letters, he is not always fortunate when managing his investments or his friendships. The epistolary tropes of the day along with Favián's confusing reiterations with slight changes when prioritizing the list of items make Favián's conception of their epistolary friendship ambiguous. At times Favián seems to be requesting favors of Kircher and at other moments his letters read as if he were purchasing from a mail-order catalogue. Equally, he is sometimes Kircher's student, sometimes a customer, and still at other times, his letters read like that of a needy, overseas relative.

${ }^{56}$ In "anteojos de cañutos," the lenses would be for a tube-shaped tool such as early modern binoculars or special eyeglasses. This is one of the places in the letters where a sudden shift of topic appears to indicate that Favián has returned to writing after some interruption or break.

${ }^{57}$ See note about captromancy above. Favián is reminding Kircher of the items including the captropic mirrors that he mentioned earlier. Favián's request for a mirror displaying "una calavera o muerte" suggests his familiarity with a popular Baroque motif in painting, vanitas memento mori, which displayed skulls, guiding the viewer in a contemplation of death as inevitable and in considering earthly possessions as mere vanity. The Spanish painters Antonio de Pereda (1611-1678) and Juan de Valdés Leal (1622-1690) both produced well-known still-life vanitas paintings showing death as a skeleton or skulls as moralizing reminders. Poetry of this period also made use of the motif. ${ }^{58}$ Kircher is being asked here to act as a "trend consultant" of sorts, which a teacher or fatherly figure might be happy to do.
} 
422 which has a title, ${ }^{59}$ Nova inventio componendi astrolabia cum horologiis artificialibus Iacobo Hayeto ingeniosissimo horologiorum serenissimi Sabaudiae ducis artifici prope finem. ${ }^{60}$ And other items of pleasure to Your Reverence which will also please me because I believe that we are of the same nature and the same intellectual disposition, ${ }^{61}$ and so will concur about everything.

[14] Regarding what I requested of Your Reverence about whether there were books that treat of and demonstrate the art of geared clocks and their movements, I ask, through the love of Our Lord, that you not forget that such things are my only entertainment and that I would like to learn more about them in order to work at it with a solid understanding. If the 250 reales de a ocho are not sufficient for all of these items please do not keep from sending them simply because of a lack of funds. I have asked my correspondent in Spain to ask the correspondent in Rome, who oversees the delivery of said money, to supplement whatever is necessary. He can give Your Reverence whatever else you ask for with total security, even if you were to ask for much more. If Your Reverence would let me know all about it in the response to this letter by giving it to this gentleman, whose name I have forgotten and who will provide the funds, so that I have a notice of the amount that I will need to pay. And in addition if you would give him, along with your letter, the case (or cases as necessary for it all to be well wrapped and to fit) with the books and other items, wellclosed and tied in order that they will not be searched or removed, ${ }^{62}$ with instructions to send it promptly to my correspondent so that he, ${ }^{63}$ in turn, will be able to bring them himself when he returns to this kingdom which will be on the next fleet due.

[15] And, finally, there is nothing left for me to supplicate and request of Your Reverence; forgive me for all the annoyances, but it would be an act of charity per viscera Domini nostri ${ }^{64}$

\footnotetext{
${ }^{59}$ Benedetti, Giambattista. 1585. Diversarum speculationum mathematicarum, et physicarum liber, Torino, eredi di Niccolò Bevilacqua.

${ }^{60}$ An excerpt of this particular section of Benedetti's Latin text is reproduced in Karla Jasso's appendix in her e-book Arte-Tecnología: Arqueología Dialéctica Mediación, 2013, 310-314. Jasso also reproduces a translation into Spanish of the same excerpt from Benedetti (314-318).

${ }^{61}$ Favián's "somos de un mesmo genio," suggests that they are like-minded, and may suggest by implication that Favián shares in some of Kircher's extraordinary talents.

${ }^{62}$ The ports of Seville and Veracruz were major customs checkpoints for both civil and Inquisition authorities during the colonial period. Other ports in Ostia, Genoa, Barcelona, and Havana likely had similar institutions. Favián's fear of items from Rome being lost on the way to Puebla is prophetic and was likely based upon his father's experiences as an importer.

${ }^{63}$ It appears that the person whose name Favián has forgotten is not his principal correspondent Francisco María Tassara. Favián refers to the unnamed person as someone who would facilitate the arrival of a package which "el correspondiente" would return to Puebla with: "[que] lo despache con brevedad al correspondiente para que pueda traerlos él mesmo en su poder cuando vuelva...." 64 "Through the body of our Lord," is a verse from a canticle known as the Benedictus from Luke 1:68-79. In the Douay-Rheims Bible of 1582, the Latin Vulgate text, "per viscera misericordiae Dei
} 
to have a few relics ${ }^{65}$ which would be for displaying in a church of the congregation of the Compañia de Christo which the Divine Majesty of God and which Our Lord was pleased for me to organize and to found for priests and lay persons in this City of the Angels five years ago. ${ }^{66}$ Today the order has over 400 priests and 800 lay members and has been authorized by the Bishop of Puebla, accepted by the civil authorities and local regiment. Despite being such a short time since its founding, I have had eight churches of excellent architecture built with beautiful altars, ornaments, lamps, and other endowments. Some of the church buildings have rooms and residences for the priests to inhabit. Indeed, although, we, the clergy of this city were attempting to establish a congregation of the Oratory of Saint Philip Neri [1515-1595], it had never come to be until this year, 1660, when it was established here. But mine follows the same style and way of life and has its churches in the countryside, alongside the city and not far from it; whereas Saint Philip Neri's are set to be built within the city. On some other occasion in order to not tire you more, I hope to write to Your Reverence and inform you very clearly about a matter in this curia, which I have faith in Our Lord whose greater glory ${ }^{67} \mathrm{I}$ seek as the glorious father Saint Ignatius did, ${ }^{68}$ wherein I may avail myself of your patronage and assistance because with your help it will certainly be successful. I believe that God's Divine Providence has made it possible for me to make Your Reverence's acquaintance, you, because of your virtue and holiness, books and merits, have such influence with princes and persons of consequence; as such you can bestow favor and honor one who dignifies himself as your disciple, who esteems you as an oracle of the sciences, and has genuine affection for you as a beloved brother in Christ Jesus. May you be granted even more grace, be kept in good health as a light of the world; it would be to our honor and by the glory of God if we saw each other in Heaven since here on the earth we cannot.

Amen, amen. The date today in this City of the Angels of New Spain, is the $2^{\text {nd }}$ of February of 1661.

Humble servant and chaplain of Your Reverence who kisses your hand,

Don Alexandro Favián,

nostri," is translated: "Through the bowels of the mercy of our God." Favián leaves out the word "misericordia" (compassion) and introduces the Latin phrase with "caridad" (charity) instead.

${ }^{65}$ For images of these artistically and culturally significant colonial artifacts in New Spain, see Egan's Relicarios (2020).

${ }^{66}$ During the colonial period, the official name of Puebla was Puebla de los Ángeles as it still is.

${ }^{67}$ Favián is referencing the Jesuit motto which Kircher would certainly recognize, A.M.D.G. Ad majorem Dei gloriam, meaning "For the greater glory of God."

${ }^{68}$ Ignatius of Loyola, who was canonized in 1622 just two years before Favián was born, founded the Jesuit order (Society of Jesus) in 1539. Favián is invoking a famous founder and thereby emphasizes his own achievements as a founder of the Congregación de Christo in Puebla although he also calls it the "Compañía de Christo" in section 15 of this letter, no doubt because he is thinking of the Jesuit order which is the Compañia de Jesús in Spanish. 
Unworthy presbyter of the Congregación de Christo.

APUG. Vol. 558 EPISTOLARIO KIRCHER

IV, Fols. 120r-121v; 141r.

\section{Letter 2}

Father Athanasius Kircher,

My most Wise, Reverend, and Beloved

Father:

I do not know how, with which words, or what style to use for expressing the great pleasure and measureless joy that my spirit felt when I saw, received, opened, and read the letters from Your Reverence. Truly, I am as astounded as I would be if I had been told that I had been named bishop of my patria or of some other great province ${ }^{69}$ not that I desire or crave such an honor, I am simply making the comparison because one of my closest relatives by blood and lineage was installed by a great noble using impressive dictates. It feels the same as if I had inherited, without knowing how, plentiful and vast riches, comforts, and conveniences, all that could possibly be imagined. I would not need to see all these, nor would any other great occurrences need to happen for me to have the pleasure and joy that I felt when I saw Your
Reverence's letters. They arrived on the glorious day of Saint Francis, and, later the trunk arrived as well with all the items that you sent. And none of this is flattery, exaggeration, or mere politeness, but rather the truth of my great emotion, born of the great magnetic ${ }^{70}$ sympathy of temperaments which I must have with Your Reverence, because the love, inclination, and affect that I feel and which I can say just as the other philosopher did that I have been born in this world only to behold, venerate, and praise Your Reverence. ${ }^{71}$ So happy and blessed am I in this way that I would not exchange this fortune for the greatest in the world; and after this there is nothing that I could envy, nor could I desire anything else other than the blessings of the spirit direct from Heaven as I serve and love God, for which, I am certain that having met Your Reverence because of your holy way of life, which I will endeavor to imitate in the exercise of instruction and holy doctrine of your works and admirable writings, upon which I shall spend the rest of my life, tirelessly, as I will be absorbed and occupied with the workings of its marvelous content. I shall be engaged in such praiseworthy endeavors, which I hope to the Lord our God, will result in my betterment and in that of many others in these kingdoms. Favored by such a

\footnotetext{
${ }^{69}$ This mention of a bishopric and an unexpected windfall of worldly comforts may suggest that Favián already had the idea of becoming a bishop early on in his correspondence with Kircher. ${ }^{70}$ The theme of magnetism is an interesting one which Favián uses to allude to Kircher's earlier works (Ars magnesia 1631, and Magnes sive de arte magnetica 1641, 1643, 1654) about the sailor's bugbear, magnetic declination, and its cosmic source in divine love. For a discussion of Kircher's theories of magnetism see: Udías (2020).

${ }^{71}$ Favián's sentences are filled with the phrasings of prayers and poetic usages. Though Favián does not name "el otro filósofo," the idea of love between two matching halves recalls Aristophanes" story in Plato's Symposium. Kircher's understanding of magnetism as a manifestation of divine love seems to have influenced Favián's descriptions of their epistolary friendship.
} 
great master, I shall, hence, dare to have some of the minor works, which I have written, printed $^{72}$ with the authority and illustrious wisdom and doctrine of Your Reverence. Thereby, my work will merit through such illustrious trappings and fine associations with you the praise and acceptance that its roughness and disheveled nature would not have gained on its own.

[2] So great is my estimation of Your Reverence's letters that soon after receiving them, I started making a bronze chest for storing the letter and any others which I might receive since Your Reverence will be sending an image of your likeness as well. There are two purposes for having your image. Firstly, it is in order to know by sight the beloved person, to whom so much is owed, whose portrait should be present, and secondly so that the best painter in these realms can transfer the paper image of Your Reverence onto a magnificent canvas, which will be elegantly decorated. It will be on the main entrance to my library as an image of the greatest marvel in the world today.

[3] After a few months of not hearing from our friend Father Ximénez, he sent me word of having received two more letters from Your Reverence. He sent them to my home so that I would see the kind words that Your Reverence favors me with despite my lack of merit; how greatly I appreciated his gesture!

[4] The box which Your Reverence sent by way of my faithful correspondent and courier, Jesús Ansaldo, arrived here in Puebla de los Ángeles after a safe voyage. It arrived intact: without a single item which Your Reverence generously sent me missing, according to the list of contents with the prices and fees that Ansaldo gave me. Likewise, were included all of Your Reverence's books in addition to the other books sent. There were no breakages, and thankfully the clock arrived without a single broken part. Everything might have gone wrong if the trunk had come out of place within the larger crate in which it was packed due to the swaying movements of transport. It likely would have been prevented from continuing its journey even if this had happened only twenty leagues from its destination; things could have become lost or very damaged. ${ }^{73}$

[5] I confess, truly, that I was dumbfounded by the contents of the trunk, such an extremely new and ingenious sight, that surely there has never been anyone here who could even understand the function of your machine. How astounded and perplexed I felt as I contemplated how I might be able to assemble it and make finer adjustments when I have

\footnotetext{
${ }^{72}$ This unaccomplished matter of Favián's works being published recurs in later letters. In 1667, during the period when Kircher supported Favián's efforts to obtain a bishopric, Kircher dedicated the Magneticum naturae regnum to him and also included an excerpt from Favián's writing about a seashell which was thought, in New Spain, to cause paralysis.

${ }^{73}$ Favián uses a chatty, informal style of narrating events: he adds a bit of melodrama here about how the trunks might have easily not arrived, a discursive touch which, depending on the circumstances, might have been entertaining or impressive to a listener in an actual conversation.
} 
never seen an example of one working. And moreover, the parts have spread out so that it seems no two pieces which fit together are near one another. Some of the parts were in the corners of the large container which held the books. ${ }^{74}$ But in the end, vexatio dat intellectum, ${ }^{75}$ and after much attention to the task, I stumbled upon the correct movement of the parts and the arrangement of the timekeeping mechanisms because, you see, the wires had come loose and become confused. I confess that I genuinely had my work cut out for me in adjusting those parts so that, for example, when it was, verbi gratia, ${ }^{76}$ nearly five o'clock the number six would be, expedita parte ${ }^{77}$ ready on the western horizon et sic de reliquis. ${ }^{78}$ It was a difficult task, but little by little I have come to understand it and bring it to its perfection. Today, thanks to God, not only is the clock running but I have been adjusting it so that it will keep time accurately which requires the regular movement of a weight. It ought not to swing so strongly as to bump into the opposite interior wall of the box nor to hang so slack and remiss as to lack strength for a full twenty-four hours. Either extreme has been a challenge to remedy because if I weaken it so that the weight does not occasionally bump into the internal boards, which include the one with a shaped cut-out that must have been designed specifically for the weight to swing through without knocking into it, then it lacks the strength and endurance that it requires to last the full twenty-four hours. The only way that I have been able to remedy this difficulty in adjusting the strength of the swinging weight is to wind the clock every twelve hours. It is in this way regulated with the sun although this action prevents the winding spring from ever unwinding fully. ${ }^{79}$

[6] It seems to me that what the inventor should have done in order to have achieved complete perfection with this device was to have made the spring, which rolls up inside the box, longer and stronger so that it would reach a full 24 hours with equal movement; indeed, it is this piece which brings the device to life. Additionally, the space where the spring rolls up would need to be larger for the longer spring, which would necessarily result in expanded movement and would last the correct amount of time before needing to be wound with its key. Moreover, lately, through whichever fortune it may be, this clock has been deemed the most rare object in the world and has caused great admiration here. Its fame has increased because it makes understandable to all that this invention is not only a clock but also a demonstration of perpetual motion with all four

\footnotetext{
${ }^{74}$ It is possible that Favián disassembled the clock in order to learn about its inner workings before reassembling it and writing this section.

75 "Frustration develops one's understanding."

76 "For example."

77 "Unimpeded."

78 "And so on."

${ }^{79}$ For the history of science and technology, this technical discussion of an early modern clock may be one of the more interesting sections in Favián's letters. It is also indicative of Favián's approach to solving problems.
} 
of the conditions that are required for it to work.

Not till now, in this age, has anyone been able to achieve this, and truly, once they have seen it, they wonder how it could be and what you wrote me takes place: ita quidem ut omnibus aspicientibus motuus perpetuus videatur. ${ }^{80}$ Since there are few people here who are knowledgeable of these sciences, it has been easier for all to believe what I say about it. To me this device has been an admirable entertainment, and to everyone else it has been the source of tremendous admiration. In sum, it is a precious item that I have greatly appreciated for its novelty and rareness, and also, for being such a source of pleasure and entertainment to me.

[7] I am supremely grateful that all of Your Reverence's books arrived without any being left out. It is infinitely magnanimous of Your Reverence to have deprived yourself of your personal copies in order that I, your most humble, least deserving servant, should receive them without having served Your Reverence in any way and without your owing me anything. Furthermore, in the end it is not possible for such nobility to remain hidden nor such magnanimity of spirit to be concealed, no matter how one may attempt to mask it. I am reading through each volume because it is so singular a pleasure that I have in reading them that I would rather not set them down day or night. As I read them, I am making notes on the materials that best match my current purposes and understanding, as well as the matters which illustrate my understanding, for, as I've mentioned before, my rough and humble works which I am sure will be sufficient to be accepted here, not because of their author but because of the illustrious patron to whom they will all be dedicated..$^{81}$

[8] I greatly appreciated the other books which Your Reverence sent me, for being about the same kinds of materials as referred to before in addition to the small copies of De crucibus prodigiosis because they are relevant to Saint John of the Cross whose spirituality is the foundation and direction for my Company of Christ and which runs through the whole enterprise, for this way of the Cross is a via crucis. $^{82}$

[9] The other items which you sent have all been so celebrated and admired that no one, from the highest levels of society to the lowest, has failed to cajole me into showing them. My entryway has not been without visitors for a single day as people keep turning up in order to satisfy their curiosity about Your Reverence's marvelous items.

[10] Our most reverend bishop of the Puebla diocese, Diego Osorio de Escobar y Llamas, is

\footnotetext{
80 "All those who look upon it, indeed, see motion."

${ }^{81}$ Favián is clearly referring to Kircher as his "maestro y tan ilustre mecenas."

82 "Way of the Cross." This appears to be a play on words referring to both John of the Cross and the Way of the Cross in Puebla, which Favián has invested in refurbishing. From here on, my translations from Latin will focus on the more obscure expressions. Latin book titles remain untranslated. When Favián refers to Latin book titles in Spanish instead of Latin, I have kept his version of the title.
} 
a great friend of mine and honors me more than I could possibly deserve. Indeed, our mutual and beloved friend Francisco Ximénez, is the bishop's confessor, as is fitting because Ximénez's many virtues, his learning, and his kindness deserve to be praised and regarded by all the world. The bishop was very impressed and pleased with all that he saw, when he visited me, and today both are in Mexico City because Bishop Osorio de Escobar y Llamas has just been elected to become the archbishop of that metropolis.

[11] The requests that I humbly make of Your Reverence, trusting in the generosity that you do me, consist of the following:

[12] Firstly, the Arte Combinatoria and the Mundo Subterráneo which seem to me may have already come out in print. And if Your Reverence has published others in the meantime, it would be a blessing to have those as well because any works composed by Your Reverence would be a great loss to leave out.

[13] I would also like to appeal to Your Reverence for a few books which are not available here and which I have already attempted to find: the work by Father Jeronimo Natalis printed in a folio edition concerning the life of Christ including his acts, parables, and miracles organized according to the four evangelists.

[14] Of the same work, which I expect has already been reprinted in a smaller format so that it is more convenient to carry on one's person, it would be very gracious of you to send two or three along with the large format copy because I need the small format ones if they are available.

[15] Another folio volume that was printed there in Latin that is entitled, I believe, Historia de las plantas, árboles y animales de las Indias is one of those. ${ }^{83}$

[16] A medium-sized little book, printed in Antwerp, full of images of divine and human love, with the title of Amoris divini et humani antiphatio, compiled from the writings of various saints, doctors of the Church and from Holy Scripture. I have one here which I acquired in an unexpected way, but it is torn and is missing many of its images. ${ }^{84}$

[17] Since among those texts which I petitioned Your Reverence for included The Art of Clocks with Gears I am very surprised to hear that it was not available since it seems to me to be a topic much written about in Europe. You explain that the theme is so frequently published about as well as being a popular

\footnotetext{
${ }^{83}$ This may be Francisco Hernandez's Rerum medicarum novae hispaniae thesaurus, seu plantarum, animalium, mineralium mexicanorum historia cum notis Joannis Terentii Linexei. Roma: 1648. For more on this exceptional work see: Varey et al. (2000).

${ }^{84}$ These missing illustration pages inspire Favián to make use of printed book images for the preparation of his own potential publications as he explains in a later letter.
} 
activity that everyone knows about it and few authors would want to write about such a commonplace. I agree that it is true, however it would only be that way there because in many other parts of the world, the opposite is the case especially in these kingdoms where there is little knowledge of clockwork, which if it were known here, the list of titles would be eternal about which matter I shall attempt to explain. Moreover, as Your Reverence has written, my hopes might be fulfilled regarding this subject once Our Lord grants Your Reverence with printing the Ars magna gravium et levium seu mechanitus thaumaturgus. Oh, may the Lord keep you in good health and give you many years of life so that the world will benefit from such a pleasing and admirable book. If you could send this book along with any others which have yet to be printed because they will surely be greatly esteemed and valued since they derive from such an author who appears not to be able to, even if he so desired, work imperfectly. I request enthusiastically that I may always be permitted to obtain Your Reverence's books as soon as they are printed. ${ }^{85}$ That you may not forget the most unworthy of your sons, who loves you most and is your disciple even if the most minor because he esteems and venerates you most.

[18] It seems to me a very good idea that all your works will be reprinted together in
Amsterdam by Jansonius, because it seems to me that his is the best printing house in the world. The new printings will turn out admirably and without erratas. I have a Janssonius imprint with a gilded vellum binding, the Nuevo Atlante del mundo, in four large volumes containing many maps, which is a recent publication that I esteem very much, and that a friend brought me from Europe. ${ }^{86} \mathrm{I}$ also have very small books from that printing house about poets and Latin prayer books which are impressive sights.

[19] Again I petition Your Reverence for more imprints. Although the ones which arrived the last time were beautiful, many similar books already exist here. This time I ask that Your Reverence will do me the kindness of sending large format books with many illustrations which sometimes arrive from Europe; they are extraordinary. I was given one once as a gift by a priest in the same Society of Jesus as Your Reverence. He is a friend who was passing through from Europe on his way to China. The book is about the mathematical sciences with a variety of hieroglyphics and well-rendered images and is bound with another title on the Last Judgement which is four varas in height

\footnotetext{
${ }^{85}$ Favián may have been hoping for a lifetime subscription in exchange for disseminating Kircher's thinking.

${ }^{86}$ A copy of this book is held by the Burgoa Collection at the Universidad Autónoma de Oaxaca. A brief physical description is available at http://www.adabi.org.mx/vufind/Record/204322 and some of Janssonius' Spanish-language titles can be found at https://iberian.ucd.ie/results.php?q=name_role:\%22Janssonius, \%20Johannes, \%20prt,\%20Printer\%22
} 
and in very good condition. ${ }^{87}$ If Your

Reverence could find a dozen or two books like these or others with a variety of illustrations including saints, hieroglyphics, and other things which Your Reverence finds pleasing I would be very grateful. If Your Reverence selects them, they will be excellent; ${ }^{88}$ they are meant to decorate a beautiful sala which I have newly built for my library. ${ }^{89}$ It is more suitable and larger than the one I had before; it is also in a better location, in the living quarters of my church. If the books were illuminated in color that would be better and more fitting for the aforesaid ornamentation..$^{90}$

[20] A ream and a half of the marbled paper painted in a variety of colors which form feathers, wings, and jasper like the ones on the binding of the octavos, De crucibus prodigiosis which Your Reverence so kindly sent me. I would like to use the paper for wrapping various costly items and for the binding pastedowns some minor booklets which I must take to the printer. I shall dedicate them to Your Reverence as I have said before.
[21] What has most filled me with delight is your short treatise Specula melitense [1638] which is truly a summary and compendium of innumerable complex matters and presented in the clearest and simplest manner. Indeed, it is very useful, as it says there, for those of us who know little about these topics. But there lies the problem: having the explanation without having the object that is described, namely the machine of the said Specula with its circles, wheels, and other instruments as in your book. I take hope that Your Reverence's promise to send this machine with the calibrations described in the treatise. ${ }^{91}$ Being such a distinctive and useful object, there must be many produced. And if by chance I were to have the good fortune of having Your Reverence send it to me, may it be well secured inside the box so that the rings and dials will not come apart the way that the clock did - that took some work to reassemble.

[22] Another two long-distance telescopes like the one you sent which had two extra lenses,

\footnotetext{
${ }^{87}$ Perhaps he meant a unit roughly equal to a foot: one vara was a little over 2 feet long and four of these would have been far too large for a book. Books of four feet "double elephant folio," however, did exist; they were grand display items in a church building and usually that size for a choir to be able to read the music as group while standing away from it.

${ }^{88}$ At the time, printing was principally done in black with the occasional use of red ink for musical texts, title pages or initial capitals. Otherwise, all use of color would have required skilled artists to apply pigments to the woodcut illustrations after printing.

${ }^{89}$ It is worth noting that Favián uses the word "librería" here rather than "museo" or "biblioteca," though he seems to mean both as these terms are used today.

${ }^{90}$ Favián must have envisioned ornamental choir books. In this letter he comes across as having the drive of a collector, as one who is highly motivated by the desire to display an impressive specialist library.

${ }^{91}$ This is a sixty-three-page long treatise. During a trip to Malta, Kircher crafted his Specula melitensis (1638), which contained a planisphere, kept track of the Julian and Gregorian calendars, charted horoscopes, and condensed medical, botanical, alchemical, and Hermetic knowledge into an object known as the 'cabalistic mirror' (Findlen 2004, 20).
} 
because these are very nice in that they extend one's vision and enlarge objects. One of them should be large and the other medium along with another two or three very small ones which have only one shaft. There are some which are a sixth of the usual size and others that are even smaller, barely an eighth of a Castilian vara. ${ }^{92}$

[23] A helioscope ${ }^{93}$ with which one observes the stars and a telescope, if they are distinct from the ordinary long-distance ones known as anteojos.

[24] Also some small lenses, already graduated, for me to be able to build a few small microscopes of that type that allow one to examine flees and other small animals. And also, so that I can make them into one of those small glasses that transform the view like the one that came with the hay seeds. ${ }^{94}$ Once we have the graduated lenses, we here, will be able to easily build the rest; on the art of lens grinding there is no one here who knows anything about it. ${ }^{95}$ And so, in order to achieve some familiarity with the matter of lens making, if there is any author of the said art of making graduated lenses for eyeglasses as well as mirrors, of which I believe that there must be many, it would be very helpful if Your Reverence could please send me one which seems to you to be best of such learning.

[25] I have also greatly admired those teachings which Your Reverence has put in the Ars magna lucis et umbrae in nova cryptologia qua catoptrica arte duo amici non tantum occultos animi conceptus, etc., which is one of the most exceptional works human minds could have arrived at. And so, in order to work on this marvel of a book if you would do me the great kindness of sending the necessary mirrors; one of metal and another of crystal in the shape of a hyperbola. It would be ideal if these two were as large as they come in order to reach greater distances and two more, if possible, which can be smaller for lesser distances as Your Reverence sees fit.

[26] Eight or nine ${ }^{96}$ more of those prisms that refract light and make many colors for executing the device demonstrated in Book 10, Part 2 of Magia parastática with the polyhedra or that which is necessary for the said affect. They should be the best that is available.

\footnotetext{
${ }^{92}$ If a vara is roughly two feet, then $1 / 8$ would be approximately 4 inches.

${ }^{93}$ This was an instrument for viewing sunspots without harming one's vision. The Jesuit Christoph Scheiner, designed a machina helioscopica by1630. A few years earlier Galileo devised an early form of this tool by using a telescope aimed at the sun in a dark room so that the spots on the sun's surface would be projected onto a sheet of paper.

${ }^{94}$ This seems to be a form of kaleidoscope.

${ }^{95}$ A glassworks was established during the rule of the first viceroy Antonio de Mendoza (r. 15351550), but it is likely that artisans of the more delicate techniques of lens grinding were not common during the first half of the colonial period.

${ }^{96}$ It is plausible that Favián needed multiples in order to send some as gifts and others for visitors to view as part of his collection. He may be distributing them among the churches of his religious order so that they all have equivalent "lab kits" at their disposal for educational purposes.
} 
[27] Some double convex lenses for examining especies in the dark, especially a large one. ${ }^{97}$

[28] If it were not inconvenient for Your Reverence to send out for a mirror on my behalf, I would be very grateful. One of each kind for operating light and shade. In these lands it is important to pair the practical with the speculative in order to arrive at the true understanding and thereby not having the instruments for experiments we must remain incomplete among speculation. Regarding the other point, because Our Lord God deemed it necessary that we be born in these lands, none of these things are found here. Nor is there anyone who can be found who would know how to make them which is the reason why I ask Your Reverence for so many things, importuning you with such bothersome requests because if we do not receive them from Europe and from persons who know about them, we will remain forever without such admirable knowledge of profound secrets and such prodigious experiences. So that we will not lack so much good, Your Reverence can forgive our boldness, the trouble, and the bother. I will always do my best to serve you and remunerate you with utmost regard and recognition. The other many things concerning documents and experiments that Your Reverence includes in your books can surely be found in these lands, provinces, and regions and thus, I only invoke Your Reverence's great kindness, for those items which are not here and cannot be had otherwise.

[29] Also in the latter category, because here there is no practice of making them, are the partitioned and halved glass spheres which appear in your Arte magnético. So far, we have run some trials using the techniques which we know already but they seem not to be the ones required for the task because we broke many in the process and we were not able to divide a single one..$^{98}$ Thus, I petition Your Reverence for descriptions of the process by which one could produce these partitioned spheres effectively. The glass which I custom ordered is of the best quality, by my estimation, and the said spheres have turned out well, although not larger than the inner spheres which according to the illustration in the book that is how it seems to be, and so because of this and not being able to cut them in half, it has not been possible to execute that large project with all the celestial movements that Your Reverence demonstrates. Reaffixing the two halves does not look like it would be difficult, since out there, in Europe, glass spheres can be divided. ${ }^{99}$ Despite our efforts, we have also not been able to free and suspend the smaller globe, which ought to have a magnet suspended inside, in the center of the glass sphere. This free suspension is the reason why we have not been able to determine the

\footnotetext{
${ }^{97}$ These tools appear to be related to his experiments with light.

${ }^{98}$ In 1542 the first glass-making factory of the Americas was established, in Puebla no less, on El Venado Street. By the time of Favián's experiments with nesting glass spheres, the factory had existed for 120 years.

${ }^{99}$ This fragmented sentence may be a subtle request for nesting glass hemispheres, already partitioned, which Favián can later fill and seal.
} 
liquids necessary for achieving the said effect. And so, I ask Your Reverence with your own words: Book 2, Artis magnetica part. 1, progymna. De statica magnética, p. 669: qua ratione huiusmodi liquores praeparari debent, et ex quibus rebus extrahendi sunt ut coniuncti numquam misceantur. ${ }^{100}$ Because in what follows, I cannot find either in the said article or elsewhere in the text cum eximium id in philosophia naturali et Chimia sit arcanum paucis notum, de eo alio forsan in opere ubi haec grata fuisse itelexero fussius et particularius tractabo, ${ }^{101} \mathrm{I}$ appeal to Your Reverence's generosity in writing me the explanation of this suspension fluid so that $\mathrm{I}$ will not be left without knowing how to construct an object of such delight and wonder as this admirable mechanism of the spheres.

[30] I am also uncertain about how to build the catoptric theatre, specifically about whether the mirrors that ought to be on the doors are larger than the ones on the inside because according to the illustration in the book that is how it appears to be. So, it is necessary that all should be the same size and if the ones on the top ought to be arched or convex, which is to say that the wood above it should be arched. And so likewise, the mirrors ought to be by necessity as well. If it would suffice that the said mirrors should be flat, because we do not have the good fortune of having them here. Even the very smallest of these concave mirrors are very costly here.

[31] I have yet to indicate to Your Reverence, due to not being about to keep in touch more frequently because of the delay of such a lengthy trip, and the fear of the letters being lost before you have had a chance to enjoy them which causes me to be so prolix and longwinded. ${ }^{102}$ All this to say that what I first attempted to build, the arca musorithmica, because it was the project that most caught my attention since it is such a new and admirable object, that could not be praised enough. This is the one which I have been least able to see to fruition. And I attribute this lack of completion to the fact that the illustration representing it lacks labels to explain the parts and functions thereof. As such, it would be a great joy and benefit to me if Your Reverence were to order the construction, there, of an arca musorithmica with its due and necessary perfection, and if possible, for it to arrive with the next fleet. I would appreciate it, as well as the other things, greatly and ask Your Reverence if you could send them regardless of the cost.

[32] The missals you sent were very beautiful. I presented one to the illustrious Don Diego

\footnotetext{
100 "These liquids must be prepared for which reason, these are extracted from the others and connected now never to be mixed."

101 "When secrets noted very little are most excellent in natural philosophy and chemistry, from that perhaps there in the works..." Favián is referencing specific passages of Kircher's books - this quote comes from page 158 of Kircher's Magnes sive de arte magnetica - to request further clarification. ${ }^{102}$ Favián indicates a concern about his letters being lost in transit. He explains that he writes lengthy letters, as opposed to brief ones, so that they are less likely to be lost before arriving since they are thick and more noticeable than a concise letter would be. Favián may be aware that the letters of the Jesuits travel in bulk via a tight network of couriers and that his own travel differently.
} 
Osorio de Escobar y Llamas, our bishop who esteemed it highly. I will keep the other one.

[33] What I also need to request and entreat Your Reverence for concerns a priest who is one of the principals of our congregation, whose first obstacle is his illegitimacy, with which he was ordained, and which prevents him from serving his chaplaincy and to which he was named because of the foundational requirements of the said chaplaincy. ${ }^{103} \mathrm{He}$ is prevented from giving mass in the Puebla Cathedral where the said priest's father served many years and where he received the highest dignity as evident in the document signed in his name and included here. He has no other course of action available for living an honest life other than the said chaplaincy and so knowing that I was planning to write to Your Reverence he wanted to ask for my aid on this occasion as the local diocesan judge and our bishop recommended to him. As such he has asked me to entreat Your Reverence, which I do now, to request a brief pontifical document with a dispensation of the said impediments so that the priest will be able accept if the opportunity arose to other posts as he truly deserves due to his nobility and primarily for being an exemplary priest, composed and virtuous. It would be an act of mercy for Your Reverence to assist with this, and I would esteem you highly for it all so that the priest will find assistance. I am sending Your Reverence 50 pesos, for the document processing fees that tend be incurred in these cases. We are not sure if it will be enough, because neither he nor I know how much it might cost. He was informed by another priest who recently obtained the dispensation and had sent this much. Through the love of Our Lord, I ask that Your Reverence will do this good deed.

[34] In my last letter I told Your Reverence about my new congregation of priests that Our Lord had allowed me to found in this city, even though I am truly undeserving. And, also, that the congregation's goal is to help us, the secular priests of these lands to live a holy life, exemplary, composed, and virtuous, for those who may want to make use of this approach. For which I chose the institution that has always, since the beginning been known as the Via crucis or Vía Sacra, which began when Our Savior was condemned to death by Pontius Pilate, walking with a measured pace until his death on the holy Mount Calvary. We mark out a route from one site to another in recollection of the path that Jesus took with the cross on his shoulders, according to the scriptures and the ancient measurement of twelve stations. At each we are in the process of building a medium-sized chapel with nicely adorned altars. And upon the altar, is painted the image of the mystery that Our Savior's works at each station and very luxuriously furnished, with lamps of silver, candelabras, altar linens, and

\footnotetext{
${ }^{103}$ Here Favián is requesting Kircher's assistance on behalf of a fellow priest who appears to have been the illegitimate child of a priest who served at the Puebla Cathedral. It is not clear whether the father of this illegitimate priest had been ordained before or after fathering him: the exact particulars of the priest's state of "bastardy" are not at issue.
} 
everything which a church needs for the celebration of a Mass which is celebrated at each station every day of the year. Each church has outside its sacristy and all the above mentioned, its small dormitories and orchards, everything small and supremely devout so much so that no one leaves who is not edified spiritually. All of this seemed impossible, because of the great sums of money that the renovations would require, and because of the weakness of my poor spirit as I proposed the undertaking. But when God wants things to happen, they do: quia contemptibilia et ignobilia Mundi elegit Deus ut confundat, etc. ${ }^{104}$ It is true that these stations of the cross existed already in this city, but they were nothing more than tiny dwellings for hermits, small and made of clay where not even two people could stand upright and sometimes not a single person could. The chapels were unadorned and were exposed to many dangers because of their solitude in the countryside. Without pews and in ruins or misused, and because they were no longer holy places, destined to the memory and representation of the sacred passion of Christ and adorned with so many graces that the Apostolic See grants them rather than the opprobrium, scandal, and dirt as dens for thieves, where they have done many grave sins which came to my attention each day, and seeing the little or lack of reverence which was had at these holy places and hermitages and this devotion and the knowledge of so many graces, which were completely forgotten in this city, and indulgences as are conceded by the Church to those who follow the stations of the Cross on the days of Lent, and so it was all lost and without parishioners. These were all reasons for which I considered, for some time, how I might be able to remedy the situation and to persuade this community to return to this holy practice and support it with their donations for the many, costly renovations. And ultimately how to return to the interior calling and inspiration of God, who ever since I was a boy, not only moved me and called me for such a great enterprise but also carried me towards it. Despite my many attempts to forget the project, it was not possible to do so because the vivid imaginings of these things returned to me such that I consulted with pious and learned persons who encouraged me to take up the task, but I was not daring enough to do so because it seemed impossible. If Our Lord God had not worked great miracles clearly and distinctly in me, which in this case succeeded, and I recognizing it to be most evidently and clearly the will of God and it seems confirmed because today my hopes for the project have been accomplished. Seeing it all as if it has been a dream, because that is how it seems to me sometimes, not only what is done but also what is yet to be done, because it has happened in so few years and all twelve churches are nearly complete with the addition of two more churches for the Holy Sepulcher of Christ Our

104 "God confuses great people by choosing the lowly for his tasks," (1 Corinthians 1:28). Favián seems to suggest that he is a modest person and not boasting about his role as a founder. 
Lord, and the cave where Saint Peter reclined and cried, so that we too can imitate him there.

[35] Their construction makes use of different kinds of architecture, each adorned at great cost, with all that is necessary for prayer, with a small residence for the priests that may want to retreat to a virtuous, exemplary, and contemplative life. So that with this they may fulfill the immense responsibilities of the priesthood, for which all this and more is required. Today, thanks be to God, we have the great example of this city and the approval of the religious orders in the form of a brotherhood and congregation named "Holy Company of Christ," 105 which the bishop approved and conceded a license for us to live in a community, to give Mass every day of the year, and to preach; also, to offer confession and give Communion alongside the other ministries. The bishop is so pleased with us that he visits frequently.

[36] In this way, thanks to God, the solution to all that I have described has arrived. Where there was once no one, there are now so many people visiting these sanctuaries especially during the Lenten season that the well populated city of Puebla has emptied while everyone visits these holy Stations of the Cross. The frequency of participation in the sacraments of penance and the eucharist is great all the year round; more so in Lent, such that on
Fridays during this time, I have not infrequently listened to confessions for the four hours before sunrise. During this period, the chapels are adorned with great devotion and recently there have been so many blessings which have come to this place from these practices that entire books would be insufficient to give a full account.

[37] This is the current state of things, and as I wrote to Your Reverence in the other letter, I could not believe but that God had ordained that I meet a person of such importance, gravity, and influence as Your Reverence, so that when it should be necessary to propose this in the current Roman Curia before all those aristocrats, your person may favor and assist this cause as an instrument that God with wisdom and providence has granted for its completion. Upon my colleagues' seeing the letters from Your Reverence and their coming to understand the great influence of your person, they now understand that God has granted us Your Reverence's assistance in achieving a papal confirmation of our humble confraternity and Congregation of the Company of Christ Jesus the Nazarene. All this in the hopes that this foundation may always sustain these sanctuaries, in perpetuity, as a retreat from the world. So that they maintain continuous prayer and contemplation of the holy mysteries which are depicted on them with regular reflection on the inspirational quotes.

\footnotetext{
${ }^{105}$ Information about this religious order is difficult to find in the Puebla archives in part because its name is so similar to that of the Jesuits: "Compañía de Jesús" vs. "Compañía de Christo." In his later letters, Favián describes how this congregación of secular priests was combined with a brotherhood open to non-ordained persons, also under his direction.
} 
All this, in order that it may benefit clerics and the reputation of priests generally because in this kingdom, the priesthood is profaned and not well esteemed. As ministers of the Lord and his church, may we offer the good example which is necessary to all and principally to these native peoples who have recently been converted to Catholicism and who are much harmed by witnessing from us any act that is less than honest. The Exercises of Saint Ignatius are at the center of this Congregation's devotional practices because I have sought the assistance of the saint in making the Exercises available to all, clerics, and laity alike, so that the prayers are accessible because here, in the Jesuit Colleges, the Exercises are not practiced by outsiders but only by those who know it already. This is one of the reasons why I named this congregation the "Company of Christ Jesus the Nazarene," in imitation of Saint Ignatius of Loyola who is our great patron and an inspiration for those who have taken clerical vows because he improved on it tremendously by way of a religious order that is so illustrious and important. We would like to be similar even in the slightest way to such a great "mother" by wearing narrow priestly robes made of humble materials as Your Reverence does, thereby dispensing with the splendor and ostentatious silks and gold which priests wear here.

[38] Therefore I, quam vis vilissimus ac inidignissimus, ${ }^{106}$ and all these priests, humble servants, sons of Your Reverence, choose you in the name of the Lord, as our protector and advocate in this holy enterprise, keeping us in your blessed hands so that from them we may come to know the good which we seek and the glory of Jesus the Nazarene and his sacred passion, which we have restored to these kingdoms. May the work of this congregation strengthen the priesthood as is our goal; may it serve its purpose to the lay public by offering confession and other practices of the faith; may it help the souls in purgatory; may it continue to gain graces and indulgences, as the Church once conceded them for its aid with the new fervor which all these kingdoms would show if the Holy Father approved and favored this pious cause.

[39] And so, by the Lord, for whom I have worked so many years and have spent the great inheritance which my parents left me, leaving myself impoverished for this cause and suffered grave illnesses to the point of receiving extreme unction. I have undergone many grievances, difficulties, and dishonors. Hence, I request of Your Reverence, humbly, that you will not shun taking on the care of our project with the concern which would be Your Reverence's gift to God, bringing you the esteem and praise deserved, and so, I hope that you will let me know in what ways we may remunerate Your Reverence with whatever we can in order to repay you in the ways that you might need.

[40] I have been so blessed with such great gifts that Your Reverence has sent to me, that I find myself overwhelmed and not knowing how to

106 "How the Lord seeks the least worthy." 
respond in kind to the great liberality and generosity with which Your Reverence has shown me, without my having previously been of service to you partly because there is little that would be of benefit to you which I could do in this place, and partly because I do not know what, if anything, here might make a pleasant gift for Your Reverence. If not for drinking chocolate being to your liking, as my correspondent Chucho Ansaldo has told me, to whom Your Reverence mentioned having written. This pleased me greatly when he told me because that is indeed something which I can send. Truly, when I wrote to Your Reverence the first time, I wanted to send some chocolate, but I dared not, imagining that it was not thought pleasing or fashionable in Europe and that it might not be valued. But now I know that I was mistaken and can make certain that you are supplied with chocolate with every crossing of the fleet. I am now sending you 100 chocolate disks, weighing a libra each, of what I think is the best quality made in these lands. It is made from the very best cacao which is selected seed by seed as are the rest of the ingredients which are all healthy and delicious, especially the ambergris ${ }^{107}$ and musk, which is extremely expensive here. Each chocolate disk has at its bottom a dried chili pepper opened with another facing in the opposite direction underneath in order to prevent the odors of the sea voyage from seeping into the chocolate and spoiling its fine perfumes. May the Lord preserve the chocolate so that it arrives in Rome in the same state that it was sent from here with complete perfection. The reverend nuns from the Convent of Santa Inés de Montepulciano alone have ground and prepared the chocolate because they have my utmost trust. In addition to 100 libras, ${ }^{108}$ there are another twelve smaller chocolate disks so that Your Reverence may make gifts of them, if you wish, to deserving friends and another six of the larger size for the friend of Your Reverence who kindly wrote the letter with the excellent penmanship which read: "colleague" on the cover. His chocolates do not have the edible silver coating.

[41] I have not been satisfied with sending Your Reverence such a trivial gift and so have been searching out all the valuable, interesting, and impressive objects that I could find in these lands in order to send, thereby returning in some way my thanks. For this reason, I have consulted our mutual friend Father Francisco Ximénez who told me not to make unnecessary purchases which might not bring any benefits because the many things which I could send, other than the chocolate, would not be considered valuable or worthy of estimation in Europe and so, if I sought to send the right gift, then I should exchange the money which I would have spent on searching out and purchasing various gifts for a bar of silver which might be of more use to Your Reverence

\footnotetext{
${ }^{107}$ Ambergris was added to a range of luxury desserts during the late medieval and early modern periods.

${ }^{108}$ The "libra" is a unit of weight and has historically been divided into twelve, sixteen or twenty "onzas" depending on the region. In Mexico, today, it refers to 16 ounces.
} 
for the costs of book impressions and your other expenses. Father Ximénez's suggestion seemed reasonable, since this way the illud opus quod iam confectum est et prestolatur maecenatem ${ }^{109}$ will be published and if this one were printed then you would have another, hopefully the Thaumaturgo mechanico.

[42] For this reason I am sending Your Reverence two bars of pure silver along with a third smaller one; all three are stamped with my initials "AF." The larger bar is worth approximately 106 pesos for Your Reverence. The medium-sized bar with the smaller one are worth nearly 90 pieces-of-eight so that Your Reverence can use it to pay for the items which I listed above as they are very important to me.

[43] I would have liked to have been able to send a greater gift of silver and some gold if I had not already spent great quantities of ducados on the construction of the Congregation's churches which have left me short on funds. But if Our Lord grants it, I will be able to send a more considerable sum on another voyage of the fleet. I am also sending Your Reverence a glorious portrait of Saint Athanasius your namesake, which I sent to have produced with the utmost care because there is nothing done so carefully as the excellent colored feather art. We believe that nothing is as rare and notable as this form of painting made by the indios in Pátzcuaro, in the provinces of Michoacán, more than 200 leguas from here. ${ }^{110}$ The paintings are not made with pigments or brushes, but rather with that excessive calm and patience which characterizes them as they arrange such a great variety of small feathers in so many different colors. They layer the feathers expertly until they have reproduced the image. The effect of the blue and purple and so many other colors are worthy, truly, of admiration. The work of these artists is highly esteemed and is costly even here which makes them difficult to obtain - it could be said that it takes a miracle! In my case, I happen to have a friend who is a canon of a church there and another who is the local priest of another village where this artwork is made. I sent these two clerics gifts so that they might have the featherwork portrait made. With all this it cost me 35 reales and it took three people five months to complete it. One person hunts the little birds, which are extremely small and are hunted with great difficulty for which the most ingenious traps and methods are used. A second person prepares the delicate feathers and arranges them individually into color groups. The third is the artist who creates the image with the feathers and with so much dexterity that it is admirable to those who watch it done because it really cannot be done with any less effort or in another way. I believe that it will be pleasing to Your Reverence, as we have managed to have your saint's portrait made. In addition, because of how rare and artful it is I did not want to adorn it or protect it with a frame and reinforcements for two

109 "This work which is already finished and looks forward to a patron."

110 The average driving distance between Pátzcuaro and Puebla today is approximately $484 \mathrm{~km}$. 
reasons: the first is that there are none here who can do it with the due care and skill, and the second is that I thought that these mountings would be completed in Europe with great refinement, with a dark wood as well as a sheet of glass to protect it from the damage of dust.

[44] For the reasons already mentioned and because I judged that they might not be pleasing, I am not sending Your Reverence any other things this time, even though I had acquired them already. For which reason, in the future I hope that Your Reverence will let me know in your letters, what might appeal to you from here, or what you would like me to send. It would give me the greatest joy to be able to be helpful to Your Reverence and to be able to repay you in some way for your expenditures and the many gifts, honors, and benefits your liberal hands have sent me without my deserving them. I consider myself to be truly happy and blessed for having had the chance to communicate with the most admirable, extraordinary, and distinguished man in centuries, whom not even the ancients could match.

[45] I have no other wish than to see your responses, in your generous letters frequently, which I believe will be simple if Your Reverence wishes to write by way of one of my correspondents, a Genoese, Francisco María Tassara, who resides in Cádiz and has a family home in Genoa. He is a good friend of mine, and it is by his hand that I have sent Your Reverence a large box wherein all the aforementioned is sturdily packed. $\mathrm{He}$ is an honest, careful person so I trust that it will arrive well. All that I send will from now on be handled by him.

[46] My other correspondent, Gerónimo Chucho Ansaldo, has been here recently and is currently near the end of his life. He has a grave illness and was not able to return to his home; it seems that he will remain in New Spain. Moreover, if this correspondent is missing, may the Lord decide to provide me with another, equally good and better situated than the first, so that not for a lack of a courier should we lose communications with Your Reverence and fail in God's will. I hope that Your Reverence may respond with blessings and good will to my promises to serve you as long as I can with the utmost thanks for which I pray continuously to God with all my sacrifices and other prayers despite my lack of merit. I pray that the Lord may preserve your health and lengthen your life for the good of all peoples, for the light of the world, for my honor and so that we might continue as friends in heaven where I trust that the bounty of God will allow us to remain for eternity.

The City of Angels of New Spain, 9 May 1663. I kiss the hand of Your Reverence, your most humble and affectionate son, most obedient and enthusiastic student,

Don Alexandro Favián, 
Presbyter of the Company of Christ. ${ }^{111}$

[47] The day on which I packed the chocolate and the other things which went into the box was the feast day of Saint Honorius. ${ }^{112}$ It was a happy accident to have packed it that day.

[48] I ask Your Reverence humbly, to not forget to send the devotional items which are very important to me for illustrating and adorning our church altars, and to aid the people in their prayers in the chapels. If by chance there were any related to the passion of Christ, they would be highly esteemed in the churches dedicated to the passion. The other items for giving to friends, such as papal certificates, and devotional images are greatly valued because they will come from the Holy City.

[49] If you could send even a little talc, it would exceed the quantity which arrives here from Guatemala in uselessly small quantities.

[50] Also the dispensation of the priest that I have asked Your Reverence for, honestly, I am doubtful that the 50 pieces-of-eight which he sent will suffice for the dispatches and errands required. Your Reverence should let me know how much more is necessary for me to send for it to be achieved.
APUG. Vol. 565 EPISTOLARIO KIRCHER

XI, Fols. 137r-145v.

\section{Letter 3}

23 August 1664

Most Reverend, Wise, and Beloved Father, and Friend:

[1] On the $20^{\text {th }}$ of August on the feast day of Saint Bernard of Clairvaux of 1664 I received your letters from my correspondent Francisco María Tassara. One of them contained the devotional items of Saint Inés of Montepulciano with the authenticated text ${ }^{113}$ which brought immense joy to the sisters and their prelate, especially to my two sisters who belong to that convent. They have appreciated the benefit that they received to a degree that I can scarcely express in words; they are very pleased that the spiritual goal for which they prepared the gift of chocolate for you has been achieved so happily.

[2] I also received the other letter in response to my own, in Your Reverence's hand which I have barely been able to understand due to my lack of talent in Latin. But what I have gathered from them is that you received the box of chocolate, the two bars of silver marked with my initials and seal, as well as the painting of

\footnotetext{
${ }^{111}$ What follows is a postscript.

${ }^{112}$ Saint Honoratus of Amiens was a $5^{\text {th }}$ century bishop. Favián may already hope to become a bishop as he will discuss in later letters.

113 This might be Raimondo da Capua's late fourteenth century hagiography Sant'Agnese da Montepulciano; alternatively, it might be a decree of some kind. The convent of Santa Inés was founded in Puebla on April 20, 1626, and was a relatively new institution in Puebla, only four decades old at the time of Favián's letter.
} 
Saint Athanasius. ${ }^{114}$ It is only regarding the 50 pesos, which I sent wrapped in linen at the bottom of the crate that I have not heard from you about. These were sent in regard to the issue of that priest, whom I explained would like a papal dispensation, and for which you have not been able to send a confirmation. A delay is due to the speed with which these last two ships conveyed the new viceroy of New Spain; that is, they turned around immediately after delivering him, so they deposited the viceroy and departed without the usual delay to await more cargo. For this reason, I am not sending gifts with this letter as I have just had enough time to write it in acknowledgement, and to let you know that I have not received the case which Your Reverence has sent because the fleet from Spain normally sets out for New Spain near the feast day of Saint John the Baptist, in early July. However, the departure was changed, and the ships left on the $4^{\text {th }}$ of May in order to bring our new Viceroy, the Marqués de Mancera ${ }^{115}$ so that he would quell the uprisings in Mexico City. ${ }^{116}$ When my correspondent Francisco María Tassara arrived in Spain, from Italy with the crate, the ships had already set out. The news of this mishap came as a great disappointment. I have already written him a letter requesting that he send it on the next available ship. In the meantime, if Your Reverence were inclined to send other books or items which might have been lacking from the earlier crate, this is an opportunity for Your Reverence, in your generosity, to send any other items which I have requested since my correspondent will be able to ship it all together on the same vessel from Spain next year on the feast of Saint John the Baptist, $24^{\text {th }}$ of June. If Your Reverence could send these items so that they arrive in Spain by May or June of 1665 so that it can all be loaded onto the said ship which will set out from Seville.

[3] It would be greatly appreciated if Your Reverence were able to include that metallic mirror as well as the other crystalline one in a hyperbolic shape for use in cryptology, ${ }^{117} q u a$ catóptrica arte $^{118}$ duo amisi, etcetera, because I have not been able to ascertain from the list whether these particular items will arrive. Although Your Reverence does indicate that the three and six-sided shapes are being sent, I

\footnotetext{
114 This appears to confirm that the first featherwork portrait which Favián sent arrived in Rome and was acknowledged by Kircher. Another two portraits are discussed in later letters but the arrival of those is less clear.

115 Antonio Sebastián Álvarez de Toledo y Salazar, 2nd Marquis of Mancera was viceroy of New Spain from October 15, 1664, to December 8, 1673. The viceroy and his wife famously became patrons to Sor Juana Inés de la Cruz.

116 The previous viceroy, Juan de Leyva de la Cerda (r. September 16, 1660, to June 28, 1664) was implicated in multiple abuses which led to protest and rioting in the capital.

${ }^{117}$ The science of encoding or hiding information in an attempt to prevent an adversary from deciphering it. This appears to be one of the intriguing amusements which Favián enjoys in his free time.

${ }^{118}$ Catoptric arts are related to mirrors and optical illusions. These would have been very entertaining to demonstrate in front of an audience, perhaps at Favián's planned museum.
} 
would like to check in case they are not among them and to reiterate that I will pay for them whatever the cost.

[4] I am in admiration about what Your Reverence says regarding the helioscope; there is no one here who has not been surprised by how much it costs in Europe because we supposed it would be very little money. Nevertheless, it is very impressive that it will allow one to distinguish and recognize people from such a great distance and to see their actions, smiles and gestures as well as one can see the stars as you say in your letter. I am not without motivation to purchase one of these tools, nor am I lacking in desire; indeed, I abound with it. What is lacking is the silver and money to pay for it due to how much I have spent on the founding of my congregation as well as the chapels which I have built and the large dormitories which I have made for the priests from which rental incomes should remain for us to live on. These and the many other expenditures that I have made and for which reason I find myself deeply indebted, totaling as of today more than 25,000 ducados that I have spent. I am still another 20,000 away from completing the work and construction in addition to their adornments. That is without counting the costs of maintenance and clerical vestments.

[5] This is what keeps me from purchasing one of the aforementioned viewing instruments, like the one which Cardenal Chigi, nephew of His Holiness, owns even if it cost me a thousand escudos. Moreover, as Your Reverence has indicated that they are available in smaller and larger sizes and so lesser and greater prices. I would appreciate it greatly if Your Reverence would do me the favor of having a good one of a moderate price made which performs the same effect or its equivalent. I trust in Your Reverence to do me this great favor of sourcing it from an artisan who charges less, a price which I can at the moment pay. I will send you, with the greatest speed, the quantity which you will have notified me, for, at the moment, because of the lack of a courier to take it between here and Spain, I am not sending the silver for it at this time.

[6] I have thought much upon Your Reverence's promise to send the volumes of Father Gaspar Schott's Curso mathematico and the four volumes of the Magia natural, because books on these matters are either unavailable here or, the ones which can be found are of little significance. If in that same package you could send the volumes of the Magia natural, since they have already been published, I would greatly appreciate it along with the Mundo subterráneo which has possibly come out and the helioscope as well.

[7] According to the list that I received, all that Your Reverence has sent me consists of truly remarkable objects. Indeed, they are gifts from such great and generous hands, especially the saints' relics which will illuminate the new chapels. However, I imagined that even more importantly I would have received some things from previous shipments which are relevant to matters of learning and the sciences since they 
are instruments which we lack here because we lack artisans who know how to make such objects. Nor do we have instruments requiring the skills which I have been told abound in Europe, or other curiosities; these objects would decorate a new museum of magnificent architecture and genius that I have built in an excellent and propitious location in the spirit of your own museum. ${ }^{119}$ And so, I would greatly value all that Your Reverence might deign to send, through your largesse and liberality, for the purposes of adorning this museum of mine. In exchange for which, I will procure as Your Reverence pleases, to adorn your museum with the most singular items available to me from here. Likewise, these items could also be for the nephew to the Pope, the most Eminent Cardinal Chigi's gozaphilacium, ${ }^{120}$ if you could speak on my behalf to let him know that I will do all that he might ask of me to do in his service; it would be a great pleasure for me to do all that my modest abilities might allow. And to the most Reverend Father General ${ }^{121}$ please impart my great appreciation for the letter which he sent and also let him know that my relatives here have recognized him as very close to our family. I remember overhearing, when I was a child, the Jesuit Father General as a member of our family and genealogy in conversation with my parents; my relations have not sent a letter this time because of the rush with the fleet leaving so soon. My commitment to be of service is that of someone whose obligation is felt in his bones, and I would like to have the time to carry on about many topics for Your Reverence, but for now, my salutations to the Reverend Father, Rector of the Colegio Romano whose liberality and benevolence, I also esteem, and so, I put myself at his service as well.

Farewell, and again a thousand times fare thee well, the solace, joy, and crown among my friends.

Puebla of the Angels, New Spain

23 August 1664

As always,

Alexandro, presbyter. ${ }^{122}$

[8] I have heard that the response shall be sent, and Francisco María will work briskly in Genoa so that the couriered items can be dispatched to Spain.

[9] But there has been no response to a letter which I sent for the Jesuit Father General in Santo Domingo.

APUG. Vol. 562 EPISTOLARIO KIRCHER VIII, Fols. 4r-5v.

\footnotetext{
${ }^{119}$ This use of this term "museo" in Spanish is notable prior to 1783, when it started to appear in print; see https://books.google.com/ngrams.

${ }^{120}$ This is a treasure box or, perhaps, by extension a museum.

${ }^{121}$ It is worth noting here that Favián's great uncle, from the same Genoese family as Favián's father, holds the highest post in the Jesuit order.

${ }^{122}$ What follows is a postscript.
} 


\section{Letter 4}

To Athanasius Kircher,

Most Illustrious and Signal of all my Friends:

[1] I cannot tire of thanking God continuously for His singular favors in giving me to understand and permitting me to communicate with a person who is the glory and honor of the world, without my meriting such great happiness and fortune. The shortness of my merits could not reach on their own such supreme happiness, had not the divine providence of God ordained it; for which reason I have persuaded myself and have come to the conclusion that in God's infinite wisdom, $\mathrm{He}$ has chosen our correspondence for some higher purpose for the souls of these remote lands, because I with my secure confidence hope that all that should come and reach me from the wise and generous hands of Your Reverence should be for the great service of God, for my honor, and for the benefit of these recently converted nations.

[2] I have received the holy items as well as the authenticated certificate, from 1664, of the glorious Saint Inés of Montepulciano, which document has been the great joy of the nuns of the convent named for her, and also the joy of Puebla so much so that it is difficult to put into words. To aid in its devotion, I have added rings of silver, gold, copper, and bronze to attach them to the original devotional relic which the generosity of Your Reverend Paternity sent us along with the other relics related to the saint. It has inspired so much devotion that there have been more than 4,000 people visiting. Their church, which I have put much care into refurbishing, is in its final stages of construction, and I am making a reliquary of silver for each relic; these display cases are large so that the relics may be given the reverence that is due to them and, also so that once the church has been completed and is consecrated, the relics will be carried in the solemn procession all the way from the Puebla Cathedral to the great altar, which is already underway, of the new church. My two sisters, who are nuns at this cloister, the mother superior and the rest of the other nuns there, send Your Reverence endless thanks. And, when its time comes, there will be a confirmation which the citizens of Montepulciano, Italy desire to have of how in the Indies, this miraculous convent has come to be founded.

[3] In the following year, 1665 , on the $19^{\text {th }}$ Of December, on the day of Saint Pontiano, I received with greatest joy the box with all that Your Paternal Reverence has sent me, great gladness not only for me but for the entire city. The gentlemen, the canons of our Holy Church, the superiors as well as ordinary members of all the religious orders, and the people of this city have for a long while come regularly to ask me when the next fleet will arrive. And so, I am now showing and demonstrating daily all that Your Reverence has sent. Likewise, I have distributed among the numbers of noble and distinguished friends as well as the whole town, the religious medals, small rosaries, the 
agnusdei, ${ }^{123}$ crosses, and buffalo reliquaries, ${ }^{124}$ to the numbers of those who have come to see. If I were to give everyone who wanted a portion of it, not even all of Rome could supply it all. Everything arrived in good condition, thanks to God, although a few items cracked: most of the agnusdei broke and two of the three-sided glass prisms broke while the third was battered. And the Lord must have seen to it that for the better provisioning of everything, my correspondent and friend, Francisco María Tassara would come to these colonies again even though I did not expect it. With great care, he had the case kept there in Spain and the whole time it was there he did not rest a moment until he entered the gates to my home. He is a very virtuous man, a person of honor who deserves to be esteemed and who esteems and loves Your Reverence so much so that he says that on this return trip to Genoa, he plans to stop in Rome, in order to see Your Reverend Paternity and to meet you. That way he will be able to deliver this package that I am preparing to send Your Reverence in person.

[4] I give Your Reverend Paternity immense and immortal thanks for all that you have sent especially since I have not served you in any way and yet you have given me so many graces and enriched me with so many signs of your benevolence. And now you have hopes of enriching me with the great honor of dedicating such an illustrious and scholarly book to me, as if I were meritorious or deserving in any way, of being named in an undertaking of such honor. While in truth I am nothing but the disdain of men and the most abject among people; and so, I find myself confused and lacking and I do not know how I will be able to repay the many honors; I who no longer have wealth nor am worth anything, how could I properly repay so many great favors? Finding myself lacking and embarrassed, without knowing nor finding ways to appreciate and serve so many good things, but I will try with all my strength, as weak as it is because of the adversities and shortness of my fortune to complete so many undertakings, to send retribution and recompense for the next departure of the fleet and more on the ones which will follow. Which, God willing, will arrive the way that I hope. For it seems that no matter how much care we put into packing the chocolate so that it will arrive securely and in a good state, which is to say, without being vitiated by travel, it appears that this is not possible. And so, seeing that this drinking chocolate is so esteemed and appreciated in Europe, I, at great cost, have ordered a great quantity to be sent from another region beyond New Spain because I've been told that that type of chocolate travels well, without spoilage, even to very distant lands. Additionally, there will be another quantity, a considerable one, from here so that you will receive both varieties. Now that I know that items from here are so appreciated in Rome, I will try to send the rarest and most unique items that I can find.

\footnotetext{
${ }^{123}$ These are small, wax medals consecrated by the pope, and which confer graces on the faithful. ${ }^{124}$ Favián refers to these particular reliquaries as "relicarios de búfalo." It is possible that they were carved from water buffalo horns or animal bone.
} 
[5] Regarding what Your Reverend Father tells me about the Most Eminent Cardinal Chigi, I greatly esteem and appreciate the good that you have done for me by introducing me to such an important gentleman, so that his favor and help might be available in the future. And so, I shall procure items with the utmost attention to meeting his interests by sending whatever he might request. In preparation for this, I have begun to write to the regions beyond Puebla where rare animals, birds, herbs, flowers, and plants are found. We already have a few very interesting specimens ready to send you on this fleet, although not as many as I would like to be able to send. An explanation accompanies the list of contents which I hope will please him greatly. When you speak on my behalf to His Eminence, please convey that I consider myself very fortunate that he would make use of my ability to serve, as unimportant as I may be. Additionally, that he should let me know of anything that he may like me to send from these lands, for I will do my best with all my spirit and all my life, because my fortune has been so great as to allow me to serve him.

[6] Regarding what has taken place with the Reverend Father General Juan Paulo Oliva, ${ }^{125}$ I was left in astonishment and even today I still feel it because it has been confirmed that His Paternal Reverence is without any doubt a relative of my home and of my blood. You see, ever since I was a child and developing my use of reason, I had heard my grandparents, parents and uncles, and other close family, speak about Olivas, Olivas, and more Olivas; my grandfather, father of my father Alejandro Fabian, was named Juan Baptista Oliva. Within the family background information which I provided when I was ordained was, Joan Baptista Oliva on the side of my paternal grandparents; he was an Old Christian from a noble Genoese family. Other research into our family tree which is currently being undertaken for a younger brother of mine, named Ignacio, who is about to be ordained, and the information found is the same: nephew of Juan Baptista Oliva from Genoa. It would have been 35 years or more ago that a different relation, named Francisco Oliva, was here in our family home; he lived here just over three years with my parents until he returned to Genoa. ${ }^{126}$ What I remember being told is that he brought my father, may he rest in peace, many precious drinking vessels made of Venetian glass. I had one of these in my church as a chalice; it was used for offering water to those who had received the eucharist. One of the other priests who served this church accidentally broke the glass, and I felt so badly about losing such a precious item that I saved the pieces. If Your Reverend Paternity would do me the distinct favor of asking His Most Reverend Paternity,

\footnotetext{
${ }^{125}$ Ioannes Paulus Oliva (b. October 4, 1600; Genoa) held the highest post in the Jesuit Order as Superior General from July 31, 1664, until his death on November 26, 1681. As Superior General he oversaw all of the Jesuit provinces including the missions in India, East Asia, and the Americas. ${ }^{126}$ Favián's choice of words "se dice que [...] vivió con mis padres" suggests that he may have been too young to remember when Francisco Oliva visited his parents' home.
} 
Juan Paulo Oliva, if this family story matches what he might know about it, then I would believe myself to be the happiest, most fortunate man in the world to have earned such a great blessing, as to be a blood relative and family to such an illustrious, great, and magnificent person. I would then have nothing greater to be proud of if this were to be the case, as that which I and the other members of my lineage, who are in the Indies, and have said was true. And so, with this I will have another occasion to be endlessly grateful to Your Reverence for making it possible for me to discover my living family ties which were hidden due to the remoteness of these kingdoms. To the said Most Reverend Paternity, I send my greetings without a letter because the fleet is set to leave shortly but will send his letter on the following voyage where I will also send the gifts of thanks for those that I have received from you. Even if my thanks are not as great as Your Reverence deserves, it will at least be what my goodwill and eager thanks have been able to send.

[7] Regarding the dispensation of the priest, we appreciate the care with which Your Reverend Paternity has expedited it. Because I let him know what you have written, the priest says that he will send another fifty pieces-of-eight on the next fleet to cover the costs incurred for processing the document. That Your Reverence has sent the feather portrait of the glorious Saint Athanasius to the Emperor ${ }^{127}$ gives me great happiness not to mention the pleasure it gives the gentlemen canons of Michoacán and the bishop of that place, Don Marcos Ramírez of Prado by whose diligence it was produced. They can see that the effort which they put into it has met such high estimation that it was sent to the emperor. I believe that God has provided this good fortune for the better management of the matters which now bear my honor and are in Your Reverence's hands; and in that way for the better attainment of everything, I am planning to have a feather portrait made of you with the help of the Bishop of Michoacán who is a good friend. We will use a printed image of you from your books. I have had the good fortune recently of finding, in Puebla, a painting from Germany of the Emperor Leopold Ignatius on a pendant depicted upon the imperial eagle with all the shields on the wings of the seven imperial electors. I will ask that the portrait be made as large as possible so that it will be larger and more grandiose because it is for the emperor after all. The portrait will hopefully be completed in time to send it on this coming departure of the ships, so that Your Reverence will be able to send it to him, along with my letters for his royal majesty where, were I present, I would kneel and put myself at his

\footnotetext{
${ }^{127}$ This is a notable mention of the feather portrait being sent to Emperor Leopold I. His sister, Mariana of Austria was queen consort of Spain from 1649 to 1665 and then queen dowager of Spain for her son Charles II until her death in 1696. In later letters, Favián mentions the sibling relationship between the Holy Roman Emperor (who presumably appreciated his gift of the featherwork portrait) and his sister, the Queen of Spain, who had the power to appoint bishops in the Americas, as a hope for his promotion to a tenured church position. Aztec featherwork and other artifacts had been collected by the emperors in Austria since the mid-1500s (Feest 1990, 15, 19-23).
} 
service. With this Your Reverence would satisfy some of the great debt which I confess to owing the emperor. And so, as I am a faithful friend, I aim to relieve anyone who is a faithful friend to me of any obligations by offering as much of my aid as possible until my friend should be free of his duties, as I shall do until the end of my days for Your Reverence in all that you may need and that I might be able to help with. Even though I am worth little, and my powers are small, I will not fail to do my best.

[8] Regarding the other feather painting for Our Holy Father, Alexander VII, whose portrait I have received so that his feather portrait can be made, it is already in the works, and I intend to encourage the artists to make it as large as possible, since it is for the Vicar of Christ; but before doing so, I would like to hear from you first about whether it would be wise to have myself portrayed in the same painting; I would be kneeling at the Pope's feet and handing him a letter. The gentlemen of these parts, whom I have consulted with on the matter, think that the painting would be pleasing to its intended recipient, but I have not wanted to have it made until hearing from Your Reverence on whether or not this would be appropriate to do. ${ }^{128}$ Even if waiting to hear from you on the matter should delay the painting, it is more important to get it right rather than to introduce errors by rushing. So, if Your Reverence would let me know what would be best in this case, and if you agree then please send me a new portrait of yourself where you are seated or standing so that I can also have myself portrayed kneeling in the manner already described, and because it will not be ready to send immediately, in the meantime I plan to send His Holiness a few items in recognition for the relics and papal certificates which honor me more than I deserve. I will send four paintings, one for each of the great Church Fathers, ${ }^{129}$ made from the most beautiful feathers, plus one of Saint Peter which is being procured for me to purchase and which once belonged to an archbishop of Mexico City. Even if they ask an incredible sum for it, I will not refuse the purchase, so long as it is for sale. For the oratory or chapel where he says mass, I am also sending a cross from Japan adorned with inlaid mother-of-pearl; it is a rare and beautiful sight. ${ }^{130}$ For Your Reverence, I have ordered a new portrait of Saint Athanasius because the first one was repurposed for my benefit; a feather painting for the most eminent Cardinal Chigi; and another of Saint Ignatius for our most reverend Father General, Paulo Oliva; and another for the Reverend Father Rector of the Colegio Romano who has been so

\footnotetext{
${ }^{128}$ Favián is considering whether to include himself in these portraits: the idea is that he would appear in a standard, kneeling posture offering a letter to the subject, a common visual trope in gift portraits of the time. In Favián's case, the portrait would be a way to offer his services to the emperor. ${ }^{129}$ The best-known Church Fathers include Ambrose, Gregory I, Jerome, and Augustine. ${ }^{130}$ Significant numbers of women and peasants converted to Christianity in Japan between 1565 and 1615, see Haruko Ward (2016). Portuguese merchant ships conducted the earliest trade between Dejima Island in Nagasaki with other Pacific Iberian ports including Macao, Manila, and Malacca. From Manila, the Spanish galleons crossed the Pacific to unload their precious goods at Acapulco, Mexico (Bleichmar 2011, 15; Canepa, 2016).
} 
generous to me despite my not having had an opportunity to serve him. I would like to send gifts to, and to serve, all those friends I have made through Your Reverence. They will all thank you, if not to the extent which you deserve, then at least to the extent that my poor capabilities can reach. Would that I were wealthy and powerful or that Our Lord God would put me in a better state of dignity for Your Reverence to reap the benefits in whichever ways might best serve you.

[9] Regarding the instrument which Your Reverence says is available in the 30-palm-size for 50 escudos, I think that sounds very good, and I will include the said quantity to pay for it so that you can send away for it to be made. Or, if there are any in that size already made, you might choose the best one with the greatest capacities from among them, as you are guided in this by God-given wisdom and from the study of science and other matters. Again, I ask that Your Reverence will do me the kindness of selecting the best made of those available. And that the mechanism by which it is positioned and guided may be explained, by which I mean that the places where the graduated adjustments are to be made, that they be pointed out just as these spots were labeled on the microscope which you have done me the favor of sending. On this microscope the shaft is marked to indicate which settings work best; indeed, we have not been able to adjust the other microscope properly because these helpful markings rubbed off. I mention these things because here, none of us has even seen a helioscope before. I would also greatly appreciate it if Your Reverence could find the largest possible, because I suspect that the larger it is, the better it will help us to see. ${ }^{131} \mathrm{In}$ the end, I place it all in your wise hands, as I know from experience that you will do your best to procure the very best and largest that you can. Also, if Your Reverence could send along a long-distance viewing instrument like the last one which has four lenses; it is such a rarity the way in which that instrument extends one's vision. The two which arrived this time are very precious but not well adjusted. I have been able to adjust them to the degree that I needed, and I gave the other to my brother, my youngest sibling, Don Tomás, who is not a priest. He is truly ingenious, very interested in literary studies; he is a great poet and has written many in praise of Your Reverence and your works, poems which I will send you so that you can include them at the beginning of your books; they are written in Spanish. He has composed many works for publication, but the scarcity of printing experienced in this land has kept him from achieving this. ${ }^{132}$ Recognizing this lack, I am determined to send the five volumes which

\footnotetext{
${ }^{131}$ Favián's comment here about telescopes sounds as though it has come straight out of Benito Daza de Valdés' dialogue in his work on ophthalmology (Seville, 1623): see pages 173-175 in Runge's translation (2004).

${ }^{132}$ Favián may be exaggerating for effect here, or he is referring to a specific period when printing in Puebla had slowed due to a lack of replaceable machine parts. If the original European printing presses to arrive were still being used, then some parts may have needed to be imported as well; see Griffin's "Introduction" (1988). While printing in Mexico City was more voluminous and varied,
} 
I have finished to Europe ${ }^{133}$ in order that they will not be lost, nor my efforts come to naught after so many years: three volumes are about one subject and the two about another. And so, I ask Your Reverence to let me know how much of it could be printed and how much it would cost to print a folio-sized volume as well as how many imprints are typically made for a print run so that I will know how much money to send.

[10] I accept the offer that Your Reverence makes regarding the mirror machine, which you promise in order to decorate my museum. And I appreciate the goodwill with which you offer the other hydraulic and catoptric machines if it were convenient to send them to a distant place like this one, because they are so large. But if either of them were available in a smaller size and would be more easily transported, I would be very grateful. I would demonstrate them in Your Reverence's name at the new museum which I have made because, even though I would like to build some of them myself here, it will be difficult as there are no materials for building them in this kingdom, nor are there technicians and artisans who have the tools and knowledge to build them.
[11] I have begun to build one out of sheets of tin brought from Spain, as described on page 429 of your Arte magnético. My first try turned out perfectly and included a few clever touches of my own but required intense work and not a little money, since such materials here are so much more expensive than they would be anywhere else in the world. For this reason, I will remind Your Reverence not to forget those graduated lenses, by which one comes to know the intentional species ${ }^{134}$ of things. I would be grateful if Your Reverence could send two of the exact same magnification in the largest size available and some other smaller ones for this purpose, because I have not been able to find them locally despite my great desire to experiment with the perfection of this marvel. And if there were any of those parts with which the Criptologia nova is made, which is in your Arte de la luz y la sombra, page 913, one made of metal and the other using a hyperbolic lens, I would appreciate it tremendously, because new inventions are objects of astonishment and surprise.

[12] I humbly ask Your Reverence not to leave out these favors: sending me the lenses along with the other extraordinary little items that

printing in Puebla was not unlively, see Toribio Medina 1991. The Mexican Inquisition had active periods which would have slowed the printing of works touching on religious themes; most genres including poetry and mathematics were generally not a concern to official censors who instead focused their attention on theological works (Nesvig, 2009; Castanian, 1954).

${ }^{133}$ Favián's mention of these completed five volumes is noteworthy; scholars have yet to find the manuscripts.

134 "Intentional species" is a reference to medieval scholastic terminology coined by Thomas Aquinas. The sense organs, such as the eyes, perceive an intentional species and retain it in the imagination where the "agent intellect" transforms it into "intelligible species" and thus into the material for producing knowledge. Here Favián displays his wide reading of classic texts. 
Your Reverence might honor me with so that I may fill the new museum which I have made. ${ }^{135}$

[13] I have the works of Juan Caramuel ${ }^{136}$ and a little book of observations of the sky, in which there are many things which have been discovered using the helioscope. I learned that this instrument is large and that it is unlike ordinary, long-distance telescopes; it instead has large lenses, and one looks through them using both eyes not with only one eye as when using the other type of optical instrument. I also found in this book how the author describes his methods for studying all the sciences. Another author, who in a very large volume explains how to learn all the sciences quickly and brings together all of Your Reverence's combinations, ${ }^{137}$ Sebastián Izquierdo, a Jesuit, entitled his book Pharus scientiarum; but if I were to speak freely, I would say that these authors have stolen the teachings from Your Reverence. At least from my perspective, I understand little of their methods for teaching the sciences, nor is what they propose intelligible in so far as my grasping what they teach because only what Your Reverence writes is clear, as it seems that God has given you that grace which makes sense to all. I, at the least, can say honestly that I easily understand as much as Your Reverence writes, whereas few in these parts read even a bit of your works. Our mutual friend, Francisco Ximénez is in great admiration of this fact about my ability and even before I could write to Your Reverence the first time, had said many times that I alone in this land would understand Your Reverence with great facility. Whether his assertion was correct time will tell, but these days his Reverence is in Mexico City as a confessor to the Viceroy. If you would send him the book of languages which Your Reverence is dispatching along with all that you have decided to honor me such as the small rosaries, medals, etcetera.

[14] Regarding the confirmation of the priests of the holy Company of Christ, which, as I wrote last time I have founded, it is no longer necessary that you speak to His Holiness about the matter of confirming the religious order because of what has happened between myself, the viceroy, and the governors of this city of Puebla de los Ángeles. Because of the royal decree of our King of Spain which forbids the founding of new religious associations, it does not even permit His Holiness to confirm them without a host of requirements and protocols; it would be a processus in infinitum ${ }^{138}$ to give an account of what we clerics and religious in these realms go through. Because here, it is a

\footnotetext{
${ }^{135}$ It is noteworthy that by this point Favián has already built and begun to fill the second iteration of the first "museum" in all of the Americas.

${ }^{136}$ Juan Caramuel y Lobkowitz (1606-1682) is a Spanish-born intellectual who travelled Europe and whose works focused on mathematics and astronomy.

${ }^{137}$ This appears to be a reference to Kircher's publication from a year earlier, Polygraphia nova et universalis ex combinatoria arte directa (1663). Sebastián Izquierdo's work was, interestingly, published in London (1659); he is a lesser-known Spanish Jesuit mathematician and, like Caramuel, was also a contemporary of Kircher's.

138 "An endless undertaking."
} 
vile thing to be a priest, nun, or friar as we are forced to be managed by secular governors and are even mistreated. Today our Bishop of Puebla has been exiled by Viceroy Marqués de Mancera because he sought to remedy the excesses and harm done by the viceroy and his predecessor in this kingdom. The other bishop of Honduras, Don Juan Merlo, who was provisor $^{139}$ here recently passed away while travelling ${ }^{140}$ during his exile from home; and so, I and the venerable priests of my new congregation send Your Reverence our account of why it would be best to suspend the matter of requesting to have our religious association confirmed because we understand that even if the confirmation were ipso facto given, it would need to be obtained by me here through great difficulties and expense as it may even require me to go to Spain and present the matter to the King, Philip IV, all of which trouble and expenditure would be my undoing. And so, it will be best to leave it until God provides some alternative and opens a path for whatever is best. Not for lack of this official status is the Congregación any less illustrious or esteemed since the church buildings are nearly complete; three months from now the Chapel of the Holy Sepulcher will open and be dedicated by me as all the other chapels have been upon their reopening. Our illustrious bishop has given me such a freedom to perform these sanctifications in case he is not available to officiate. The painting of the Shroud of Turin, which you sent, is for this holy chapel of the Sepulcher and I am planning to gild it for the altar, which will not be visible until Good Friday. But returning to the topic of the Congregación, it has been approved by the Ordinario $^{141}$ here as well as all the religious orders of this realm. It has also been approved by the Office of the Inquisition and has been a means for veneration by the community for which reason have the city governors and the mayor as well as the viceroy, in Mexico City, said that it is very good and should remain local, as it is, rather than becoming the larger religious organization which I was attempting to form. Never has there been in these realms, since their discovery, a more successful criollo endeavor, nor shall there be. Here I have reported to Your Reverence the state of things as they are, such that in the end, it is not possible to obtain the confirmation and license from the Real Audiencia and the Viceroy, either that or the viceroy simply did not want to be bothered for the reason which I have mentioned concerning the issue of the patronato. ${ }^{142}$

[15] But not because of these burdens should Your Reverence refrain from requesting from His Holiness for the final confirmation to become fully fledged. Even though I was its

\footnotetext{
${ }^{139}$ Ecclesiastical overseer of the provision of goods necessary for the everyday functioning of religious communities.

${ }^{140}$ The detail about the bishop's death while travelling appears to be significant to Favián; it suggests the daily indignities suffered by clerics in New Spain.

${ }^{141}$ Ecclesiastical role invested with the authority to exercise canon law, typically a bishop.

${ }^{142}$ Favián refers to the "patronato real" which was the Spanish monarch's power to select candidates for any available bishoprics within the Spanish kingdoms.
} 
most unworthy author, it is illustrious, holy, and of such honor to God, truly a glory of Christianity and good for the souls of Purgatory, since before its founding the graces available in those most holy places were not being accessed. But now these graces are being achieved and enjoyed to such spiritual benefit. The Congregación sets a good example in this city because of the priests who attend to the chapels and take care of them. It is to the great benefit of the souls of this city that there are continuous sacraments of confession, communion and other celebrations, principally Lenten ones, which are worthy of admiration, and so it is that I might earn the Pope's most holy blessing from afar. I am moved to apply myself in newer endeavors in the service of God and the esteem of souls, which is what I work towards day and night through so many cares and much fretting, since this project is already complete. And in that way, I live in a state of disquiet so long as I lack fields where to labor, to serve in what new endeavor God may give me for serving the Church by investing my small hacienda and remaining assets in its rituals of worship. For, truly and in very real ways, I have left myself poor and have liquidated the inheritance from my parents by perfecting twelve churches, two of which have their interiors and living quarters in progress. I consider myself to be the most blessed of men for having spent it in this way for the honor and service of the blessed passion of my most beloved Lord and Redeemer Jesus Christ through this institution which God's Divine Majesty decided to put me in charge of. For, in this land the Stations of the Cross were dismissed, but now the refurbished churches provide a space for prayers. I hold on to a secure faith that in some way, the Divine bounty will provide for me in order to support myself after spending so much gold and silver, as I have, only to see God venerated. Since when it is not the centuplum accipietis, ${ }^{143}$ in any occupation including this ecclesiastical one, I trust that God's compassion will provide me with a congrua pasadía ${ }^{144}$ in temporal matters for the basic maintenance of my family and my vocation. I shall be very pleased and satisfied, habentes alimentis et aliquibus rogamur his contentissimus, ${ }^{145}$ as Saint Paul said, because all the rest is mere air. For those of us who are priests because God has chosen us, I regard whatever is not working for and serving God's vineyard to be worthless.

[16] I conclude here so as to not tire Your Reverence any longer with the tears and sobbing with which I am writing this letter, seeing my goals unmet because I am such a bad person; the work of so many years, the difficulties which I have experienced, the serious illnesses which I have suffered and that brought me so close to death, the least of which is the lost hacienda because it was spent in the service of the same God who had provided it; my greatest honor is to be able to be poor for Christ. That I have no other relief in such great

\footnotetext{
143 "A hundredfold return."

${ }^{144}$ Money provided by a religious order or a diocese to cover the living costs of priests, friars, or nuns. 145 "For happiness we pray to have the spirit nourished."
} 
sadness but in the beloved Lord who walks, bearing a cross, along that harsh path of my instituto, until he is nailed upon it by my enormous sins, and in presenting that goodwill and emotion of such great love with which I dedicated myself to his service. I offered my life, my hacienda and my honor all that I had and all it was worth in order to spend it in rebuilding his churches and chapels in the official manner which the Apostolic Bull dictates that the mysteries of the most holy Crucifixion be represented. By turning those most blessed places from foul muladares, ${ }^{146}$ which were previously used as thieves' dens, and which housed countless sins and misdeeds within the ruins of their fallen walls; now they are images of paradise and little heavens attended to by very holy priests and servants of God. Within all these chapels, enriched by admirable jewels and adorned with great preciousness, are many Masses held where the word of God is preached, and the priests practice continuous exercises of ecclesiastical disciplines $^{147}$ every evening. The local community frequents the sacraments at the chapels in addition to walking to all of the holy stations, principally during the Lenten processions with their grave penitence. This is all of such great benefit to the soul, that it is impossible to describe. Thus, the consolation that I have in my sadness is a faith in God's generosity, a prize for my many troubles in this life, of the necessary temporal matters required of living honorably, ${ }^{148}$ meeting the obligations of my family and the estate which I hold. The other prize that I hope for is the salvation of my soul.

[17] The other relief which, after God, I have in my pains, is having given myself to Your Reverence's divine providence as my father, for my refuge and protection. My affection is great enough that merely with thinking about your books and looking on the effigy of your portrait am I diverted and find rest. I spend my time alone and withdrawn ${ }^{149}$ and entertained by reading and studying your books which are all of my happiness and pleasure. And in continuing to make use of them through my rough writings, I petition fervently for help from Your Reverence that you will not forget to send me quam primum $^{150}$ the books of your Mundo subterráneo, the Curso matemático by Father Gaspar Schott, and the other four volumes of his Magia natural. ${ }^{151}$

[18] I will stop here, as I cannot say more, and I close by humbly and tenderly asking Your Reverence to remember my difficulties and pray for me to God and the most Holy Mother

\footnotetext{
${ }^{146}$ Places where waste is deposited.

${ }^{147}$ This appears to refer specifically to the priests' daily practices of prayer and study.

${ }^{148}$ Note that material comforts are part of Favián's concept of an honorable living.

${ }^{149}$ Perhaps being short on money makes him unable to invite guests over for a visit.

150 "As soon as possible"

${ }^{151}$ Gaspar Schott co-authored two publications with Kircher, a fact which Favián references in his later letters perhaps as a hint at the potential for publishing his own manuscripts within a work of Kircher's as well. For a discussion of seventeenth-century, global Catholic book networks, see Maillard Álvarez 2014, $115 f$.
} 
that they will grant me with whatever is best for the glory and salvation of my soul, as in the temporal matters so as to be able to live life with some rest, so in the spiritual matters in order to serve and work in God's vineyard for my own good and for the benefit of the many souls whom I am charged with, which is what I have always sought out.

[19] Along with all the things in the other letter, of which this is a delayed copy ${ }^{152}$ and which I trust Your Reverence will have received.

[Unsigned: circa January 1666.]

APUG. Vol. 565 EPISTOLARIO KIRCHER XI, Fols. 189r-193r.

\section{Letter 5}

To Father Athanasius Kircher,

Most Reverend, Wise and Beloved Father:

[1] This letter which appears here transferred from before, is the copy of the one which I sent Your Reverence with the ship that set sail from this kingdom only a few days after I received the box from Francisco María Tassara, a letter that I wanted to return to here on account of its importance and in case that it might have become lost on such a long journey, so that you might receive this second one. In it I have responded extensively to the matters relevant to our correspondence and so have not been able to resist spending a good length of time on it for Your Reverence.
[2] In this one now, I give Your Reverence notice of another matter, as important as the first, which without knowing how or by what cause this has come about, because, as the saying goes invitis parentibus, ${ }^{153}$ I have found myself obliged to do what I was not expecting, not once had I imagined it: Don Diego Osorio de Escobar, the Bishop of this city, as well as the distinguished canons of this cathedral and that of Mexico City, the clergy of the various religious orders and the other people of these kingdoms, knowing about our correspondence, such that by the magnificent letters from Your Reverence that have so honored my unworthiness, just as you have also enriched me with the other honors, principally the celebrated relics and the such honorific papal edicts which I have shown for all to see; having, thus, their admiration for the many things that Your Reverence is able to do, so with the Holy Father and the other distinguished members of the Roman court, such as the Emperor and the principals of the empire, and that anything which I might ask of the ones or the others in terms of a post or some form of honorary status would be very easy for me to obtain and achieve. They have pursued me, which is how I mean to say it, as persecution is what I have experienced, in so far as I write it that way to Your Reverence so that the possible errands can be taken care of for it, since God has opened the path for me without my having sought it or aspired to any great end or result. And so, based

\footnotetext{
${ }^{152}$ This "copia" contains entirely different information from the one that follows.

153 "I obey against my will."
} 
on this and other advice, they told me that it would be very good for me to have a canonry in this cathedral church or at the one in Mexico City, and that it was a shame that a person like myself should be lost and humbled for lack of a decent and authoritative position in order to illustrate the actions and heroic works that I have accomplished. Others have said that the dean of this cathedral church of Puebla de los Ángeles is very old, more than eighty years of age and that he no longer keeps up with the duties of his office. And so, my relatives, the Colones, wrote me letters from the lands where their haciendas are located to advise me strongly to solicit this deanship as a future post. Many others from this city have said similar things. Now that the distinguished Dr. Domingo de Ríos, archdeacon of this holy Cathedral, has just passed away and who was my ecclesiastical supervisor came to my home to offer his advice and to tell me to send a letter to Your Reverence, on this voyage of the fleet, about that dignity. Others with greater authority and more sophisticated advice, persons of great influence, have set their sets higher for me, saying that since I have Your Reverence as a friend, it is not reasonable to content myself with less but rather to aim at more, since I have no faults or defects which would impede it; ${ }^{154}$ and so, to ask and petition, once and for all, for me to be elected bishop of one of the bishoprics of this kingdom. And this has been such a pressing matter that it is continuous and the insistent desire of all who wish the best for me and who have not paused a moment from persuading me towards it nor from taking on the details necessary for me to obtain it. This has reached such an extreme that my very own confessor, who is a member of the Society of Jesus, has charged my conscience with it, since I did not want to either speak or write to Your Reverence about such matters, because, I confess truly before God, who is my witness, that since the day that I was ordained a priest I have never had a moment of presumptuous aspirations for such honors. In fact, I once abhorred such dignities to such an extreme and to such an extent that I then tried to avoid this when I joined the clergy because I knew about their great store of temporal belongings which God has given them, and that, with the facility they held at the court of our King in Spain, they could grant some canonship or other dignity as has been done for other priests like myself. Back then, I told myself that upon becoming a cleric I would be ordained in good faith on the condition that I would be a humble, solitary, and quiet priest in my own home, ${ }^{155}$ and so I have been until now. As is known to all in this kingdom, I have never aimed for anything more than occupying myself in my home with my books and with the exercises of prayer and the spiritual life, only leaving my chamber at the Colegio del Espiritu

\footnotetext{
${ }^{154}$ This may be our only access to a fair assessment of Favián's potential, one which is neither confused by baroque praise and humility tropes nor marred by interpersonal upsets.

${ }^{155}$ By the end of his two decades of letter writing, he appears to have unwittingly achieved these original life goals. His revised life goals reflecting a newly forged political identity, however, appear from the letters to have remained unmet.
} 
Santo, belonging to the Society of Jesus, which is attached to my home, ${ }^{156}$ in order to give the sacraments of the eucharist and confession to those who have continuously sought me out. I was there for four years, just after being ordained as a priest without leaving my chamber, it was such a melancholy and dark place without other sources of light than a small, shuttered window, by which light I prayed, studied, and wrote because I had walled up the other windows. ${ }^{157}$ Inside the chamber there was nothing more than a plank of wood where I slept, a chair and table where I wrote and ate. So great was the austerity of life that I took on, that I came to lose my health entirely, and it was so far gone that not even now have I been able to restore it by way of medicines. Throughout this retreat where I was for so long, without communicating with anyone, not even the servants, I wanted to go to Spain and become a Capuchin friar or to enter the Carthusian order because it seemed to me that, here, the religious orders were too lax and accommodating for my ascetic spirit. But it was not this suffering that God wanted from me, but rather that I leave there in order to establish what He called me for, the congregation that I had thought about for so long; and so that is how God started within me the plans for the foundation of my congregation which he had chosen me for from the age of five. I can assert with truth that since that age I was urged by His Divine Majesty for it. It has been ten years of ceaseless work and many illnesses and trials and so in the official founding of the congregation, as in the material of its making. For it is one thing to see it and another thing entirely to express how, in so short a time it has been possible to have started such a great endeavor as this and to have achieved something that others did not believe was possible in this kingdom and which held it to be risible. Today, thanks to the majesty of God, it is already in that good state about which I have written to Your Reverence in the past. And I am no longer lacking anything because there are now priests in this congregation who are much better than myself.

[3] Regarding all of this, those who desire my good have taken the occasion and motive to advise and to urge me with such insistence that I should look into and aspire to a great dignity, because it seems to all, and they keep saying it clearly, that I should be a great prelate. I tend to laugh at this nonsense when I hear it said, how misled they must be to have formed such a positive impression of me and am very much surprised by how I might seem, to such wise gentlemen, a worthy candidate when I

\footnotetext{
${ }^{156}$ Based on this description, the location of Favián's family home would have been on a side street a block or two from the central square in Puebla, which makes sense of the fact that his family's shops were on the main shopping street in the historic center. Leicht's nineteenth-century travel guide (1909) to the historic center of Puebla is a helpful collection of micro-local histories.

${ }^{157}$ Puebla has a gentle climate and a very pleasant town square with shopping in historic buildings along aesthetic, covered archways. Presumably Favián boarded up his windows to limit his temptations; he also seems to have wanted to engage in penance by making his life consciously uncomfortable.
} 
know that I am clearly a fool, a man without sense, thoroughly confused and a man in whom nothing good can be found, a beast of burden, a big donkey. And at bottom a troublesome, contemptible priest who does not even fulfil the least duties of his state. Behold how I manage to complicate the lives of others who are of a much greater state. And so, as I know myself well and know who I am, I have resisted such continuous persuasions viribus et posse 158 for two years. But now they have urged me anew, with more urgent persuasions upon the new occasion of this fleet and letter for Your illustrious and magnificent Reverence. And so, speaking of this situation with my confessor and spiritual father, who is a man of letters, very learned and accomplished, told me that he would not absolve me until I promised to complete all necessary tasks and so I am writing to Your Reverence.

[4] Nevertheless, thinking upon this with more leisure on my own, and fearing that my limited powers are insufficient for such a large task and the poor account that I might give of it, I am resolved with great determination to not think on it any longer, nor to take any steps towards it, but as soon as it became known that I had said with great determination that I would not speak or write about the matter, when two of the family members and household of our bishop, Alonso Muñiz and Don Pedro Burdeos, for whom I asked the dispensation, who have both most wanted to see me in this post entered the discussion. ${ }^{159}$ And since Don Alonso is a person of authority, as a relative of our bishop and pastor of the distinguished and glorious Saint Joseph church of this city, who then went far away from this city, with Burdeos, to the place where our illustrious bishop was unjustly exiled at the time, in order to give him an account of all that was taking place here with me and to ask him to use to his authority to command me, as he is my prelate superior, with an order of obedentia to do what so many learned men have been attempting to persuade me to do. And so, I wrote a request to obtain the dignity, and this is how it happened, in the manner that they arranged, that I was summoned within a few days to my bishop's presence. I told the bishop about much of what Your Reverence had done me the honor of sending as gifts despite their costliness. I also took him the papal certificates for the sacred relics so that he would see them and could ordain a solemn celebration for the day on which each would be opened. The blessed prelate hosted me with a great welcome of the best generosity imaginable as if I deserved such things. I accompanied him a few days there and we discussed, face to face, my matters at length, and I found him so inclined and positive about honoring and favoring me, that I had to resign myself to his will in order for him to advise me regarding what would be most just and convenient. And then at that point he asked me to kneel and being in this way in his presence, he ordered

\footnotetext{
158 "As much as is possible for men."

${ }^{159}$ Some of these powerful figures may have wanted Favián in a particular post for their own benefit as well.
} 
that in virtute sanctae obedientiae ${ }^{160}$ I not resist what God ordained and what all were saying, and that he, as my prelate, commanded me because he saw that it was indeed very convenient to the service of God and his church in the Americas. ${ }^{161} \mathrm{He}$ communicated and explained the way by which this could be accomplished, saying that if Your Reverence wanted to achieve it on your path to holiness that would be best; otherwise it seemed that it would be more difficult if it were me requesting to be appointed from the Americas because it would be necessary to request it from King Philip IV due to the monarch's patronato real over the Americas. And so, it would be much simpler for me to be appointed to a church in Spain if I were there, but since it is more likely that I will stay here, that I should solicit Your Reverence to reach his Holiness and he would in turn ask King Philip. Or if this were not viable, then a letter on my behalf from the most eminent Cardenal Chigi, the pope's nephew would suffice. Or, if the reverend father General Paulo Oliva could request it of the king, because our bishop here already knew that Oliva was a relative of mine even before I had a chance to tell him because some elders of this kingdom who knew my grandparents here and in Genoa had told him about me. My bishop said that if any of them were to ask it of the pope and suggest it to King Philip, he would certainly do it. Thus, we have seen many bishoprics provided in the Americas with very little diligence. And recently to a good friend of mine, a Franciscan, Friar Alonso Bravo, was His Majesty's grace was given, to attain the bishopric of Nicaragua, simply because the Duke of Albuquerque, who was viceroy of New Spain here, told the king that my friend was deserving and appropriate for the post. For another, a poor Dominican friar named Cifuentes, the Duke requested that the friar be named a bishop without his having held any office or post within the order. Yet another example is a Dominican friar who recently arrived from Madrid in order to hold the position of one of the best bishoprics in New Spain, which is Oaxaca, and he had risen from being a mere caballero; he started with nothing and still obtained a position like this one. And so, it seems certain that any kind of recommendation which Your Reverence might send will easily achieve what is sought. If the recommendation were from His Holiness, it would be of admirable effectiveness, making things much shorter and simpler; and if it were from the Cardinal, from Your Reverence, from his reverence the Superior General, or everyone, all the better.

[5] Another approach occurred to our bishop which he thinks may be very good as well as the most efficacious: that of the emperor for whom I had the feather painting made, as I mentioned to Your Reverence in a previous letter, so as to impress him with such a gift and gain his good

160 "Under virtue of holy obedience."

${ }^{161}$ This discussion only begins to hint at the political significance of criollo priests being appointed to episcopal positions. Favián never mentions that indios or mestizos are also underrepresented in local government and the distinguished clerical positions. 
will. If he were to ask the King of Spain, Philip IV, since Emperor Leopold is his brother-inlaw and they are related through so many relatives, ${ }^{162}$ to present me to his Holiness as a bishop for the first available vacancy in the colonies that would work. My bishop of Puebla thought this would be the best approach of all, and the most direct. Hence, I should write to his imperial majesty and send the feather portrait and if Your Reverence as well as the Reverend Father General could write to the emperor, to ask him for the grace of a letter of recommendation on my behalf for King Philip IV. And if these letters from the emperor could be entrusted to Your Reverence in order that they be sent securely to Spain, because if the emperor had to send them then there would be a possibility that he might forget. ${ }^{163}$

[6] My bishop also told me that he was going to pass by my home to say farewell before leaving for Spain, and that I should have my documents printed as soon as I arrived back in Puebla and send them on this fleet to the Council of the Indies, declaring in them my nobility, virtue, education, and the many achievements in this diocese. He gave me his word that he would also inform the Council at length about my character and merits while also writing now, on this fleet that is leaving these kingdoms bound for Spain this month, to King Philip IV, to give him an account of what I have done and how I have worked in this diocese and how much I deserve to be appointed; because he believed that it was necessary to do so at the time when the recommendations arrive from His Holiness, from the Cardinal, from Your Reverence, or from the Reverend Father General of the Jesuit Order. In the case that the emperor should already have been informed, that he has received some other notice and is aware that it is on my behalf since I have been told as I write this that our bishop is about to send the aforementioned reports to the Council of the Indies, and also that the promised letters for the King have already been sent. I have here for Your Reverence, the entire situation and what has resulted from our correspondence, about which I am so amazed and surprised that I know not what has taken place nor what has happened; I have wanted, as tiring as it must be to Your Reverence, to give you a complete and detailed description of everything, in correct measure, and how it has all been through the purest intention and honesty as God knows and in whose presence I write. I would not want it to be thought there in Europe that I seek out the position, absit, ${ }^{164}$ for by the mercy of God never have I had reason to be accused of presumption, vainglory, arrogance, or professional ambition because in this God has been merciful as I have never wanted temporal honors, but rather sought the service of God and aspired toward virtue - the rest is all air. And now, if I seek the honor of a bishopric, for all that I have spent on this congregación that our Lord wanted to put

\footnotetext{
${ }^{162}$ The Spanish and Austrian branches of the Habsburg royal family intermarried many times during the sixteenth and seventeenth centuries.

${ }^{163}$ Favián's letters can be charmingly practical at times.

164 "Heaven forbid!"
} 
under my charge, as I have already told Your Reverence in my letters, it is my desire to have no more than the bare necessities in order to live. ${ }^{165}$ And so, our good pastor and bishop, seeing the material state that I was in, said that it was not right for someone who had spent his family's property and inheritance so generously for God to be in such a state of need. For which reason he wanted to give me one of the curacies, of which this diocese has many, because it is unoccupied at present because the one who held it has been promoted to the canonship of the Church of Michoacán, where the feather portraits are made, so that I could live a comfortable and honorable life with its necessities. For the jurisdiction of this curacy is large and wealthy, more so than some of the bishoprics of these kingdoms. And he said that it was both to bolster my list of merits before the King of Spain and also so that when some letter of appointment arrived, it would find me in the service of the faithful.

[8] The viceroy of México, the Marqués de Mancera, will need to confirm the bishop's granting of the curacy to me in the name of the King in Spain. ${ }^{166}$ And I believe the viceroy will grant it easily because my friend, Father Francisco Ximénez, ${ }^{167}$ is his confessor and can inform him about my character and also because my bishop said that he would present my case to the King when he travels to Madrid. Furthermore, I have thanked Puebla's good bishop many times for his concern about my wellbeing; thus, I will say that since he has selected me for the wealthiest of the curacies within his diocese, that if it were within his power to grant me the prebends from that parish, or to assign the bishoprics to the best pastors, indeed, it seems that he would have given the best of them to me. And though he is set to leave and will recommend me for the curacy before doing so, he said that if he could not, then he would grant me the rents from his diocese because of my state of need.

[9] This is all that I wanted to tell Your Reverence, my most beloved father, about which I have been up nights suffocating with worries until putting them in writing and sending them to you. It is up to your goodwill, whatever Your Reverence thinks is best and how to order it, that will be most correct; for someone to whom God has given so much wisdom and prudence will not err. And I with this letter have completed all that my prelate commanded me to do. But whether or not this will be sufficient to satisfy God I do not know, and this keeps me up at night. But I have resigned myself now to trust in the prelate

\footnotetext{
${ }^{165}$ It is worth noting here that Favián was born into a comfortable home and a family of means; his idea of what constitutes necessities seems to be more elaborate than the residence where he finds himself in the later letters.

${ }^{166}$ Politically, this was unlikely as the bishop was leaving New Spain precisely because of a falling out with the viceroys. It is not clear whether Favián is intentionally withholding information from Kircher and attempting to make his promotion sound inevitable, or if Favián is simply unaware. ${ }^{167}$ This is poignant because Favián seems unaware that Ximénez is not his friend and will not recommend him to the viceroy.
} 
whom I am to obey, because that is the correct thing to do in cases of uncertainty, when we do not know what to do in order to do God's will. That is what is most advised, whatever pleases Your Reverence, to whom, without having met you in Rome or anyone else personally, Divine Providence led me without my foreseeing either how or in what way, our correspondence has become so firm, loyal and true in order that from it might come the greater glory of God, the good for many souls, the benefit of my own and my salvation which are the highest goals which I have held.

[10] And in this way, I petition Your Reverence fervently that you will pray for me to God, and that if it conforms to God's holy will and will be for the greater good of my soul, that God may give Your Reverence his grace and light for what he ordains in a way that it may be achieved. And if it is not meant to be in this way in order that I might amend my sins, in order to correct me and so that I will be purified, so that I may become a saint and accomplish such a grave obligation, arriving at a great perfection, may God be served in his infinity mercy. I do not seek or aim for my own convenience nor for that of my family, neither honor nor esteem for myself. And thus, I feel comforted that in this matter because my intention is upright and includes a very great desire to honor God, to work in his vineyard as an attentive worker and to look after the sheep that he might put under my care, even to give my own life for them as a faithful and careful pastor.
[11] And so it is no longer possible to set this matter aside, as here this action is in motion and begun with the notice, which our bishop will give to our King of Spain during his trip, about my person and the report which he sends and in the information that I am to send to the Council of the Indies on my own behalf. It would be good if Your Reverence could do me the favor of sending the letters of recommendation for this purpose by whichever routes the ones proposed or the ones which seem better to you. It is best if the letters do not mention any bishoprics, nor that I should be appointed to the first which becomes vacant; the reason is that there might not be any available at present, since it is common here for new vacancies to take 15 to 20 years because there are few good ones. Another reason is that some bishoprics are so poor and desolate that appointees do not typically want to accept them even when they are granted because the post is in a remote location with bad weather and great poverty. In some of these, the bishop serves as the local priest as well as the other ecclesiastical roles all on his own because there are no other priests. What we have thought, and everyone has concurred that there is no possibility at present other than the post in Michoacán, which is where the feather portraits and a thousand other curious crafts are made; indeed, all the singular, rare, and high-quality artwork comes from there. This bishopric here is Puebla which is not poor like the ones I mentioned earlier but rather of a good standing. The bishop at present is Don Fray Marcos Ramírez del Prado, a member of the Franciscan order, and a great friend, and he used his influence to 
oversee the production of the feather portraits for me to send Your Reverence, because they are costly and require much difficulty to have made. Moreover, this holy bishop is now so elderly that, as is natural, he will likely not live another full year because he was recently near death. And so, I ask for Your Reverence's mercy to ask for this post. I would count myself very happy and fortunate to be his successor, as unworthy as I am; he was my godfather and confirmed me during his last visit to this city on his way to Michoacán. And ever since New Spain was won, there has not been another bishop who has lived as long as he has, nor has any held the governance of his diocese for as long. I have made a note of this because, otherwise, there is a risk of accidentally being posted to a bishopric which is typically assigned as a punishment or as exile rather than as a dignity. I will finish now, finally, repeating a thousand times over that I place myself in your holy and venerable hands by which so many blessings, honors, benefits, and graces have come to me in such a short time, and so, I have firm hope that this next one will be the largest of all which will come to me as part of the great fortune that I had in meeting Your Reverence and that God, my Father and Lord, would give me for my shelter, my care, and my only remedy.

Vale millies et millies; vale unicum meum otium, patricinium et remedium. ${ }^{168}$
Puebla of the Angeles, of New Spain on 10 March 1666

Your Reverence's servant, chaplain, and son kisses your hand with gratitude and humility. Don Alexandro Favián, presbyter.

APUG. Vol. 565 EPISTOLARIO KIRCHER XI, Fols. 193r-196v.

\section{Letter 6 Summary ${ }^{169}$ \\ To Athanasius Kircher \\ From Alexandro Favián, 12 March 1666}

[1] After Favián completed the previous letter, a few of his friends and clerical colleagues in his Congregation asked to read the letter for themselves. Once they were satisfied, they thanked Favián heartily; they were, however, concerned that Favián had not mentioned the 5hour long Theology examination which he took when he was newly ordained. He had so impressed the bishop when being examined to determine how well he would serve as a confessor to clergy of different ranks, that the bishop decided to give him a dispensation in the number of decades necessary for a priest to become the confessor of sisters and nuns. This is a role which Favián has since performed with seriousness and devotion. His reputation as a confessor to those who are troubled or those who are inspired by mystical and other spiritual

168 "Farewell a thousand times over, my friend, patron and support."

${ }^{169}$ Letter 6 concerns Favián's achievements and successes listed for Kircher to include them in his letters of recommendation. Along with this list of merits, Favián sends Kircher a gift of 100 copies of a prayer book and also makes new requests of Kircher. 
matters have extended even to the lay public in Puebla.

[2] Favián says that his friends have also asked him to mention how he received a new brotherhood, the Confraternity of the Perpetual Love of Christ, ${ }^{170}$ which the Jesuit priest Pedro Pellegrín recently brought from France. It was a labor of love for Favián as Father Pellegrín did not bring more than the faintest suggestions of what the holy nun, Madotens of Saint Bernard, intended; as for what the confraternity's actual activities and rites were to include, that was all up to Favián to develop because, he says that Father Pellegrín had no talent for such matters. Favián labored to establish the prayer practices and expectations for the members in addition to producing a very large book over the course of five months, for a book of hours where prayers for each of the traditional prayer times of the day are available for everyday of a calendar year; he says that it was incredibly laborious to produce. The Jesuits in Puebla, including Father Pellegrín, asked Favián to take over the confraternity, seeing how much progress he had made with it, and so with the authorization and approval of Puebla's bishop, this new confraternity was joined to the one which Favián had already founded a year and a half earlier, the Holy Company of Christ. Favián encountered many difficulties until the bishop joined the confraternity and then the bishop of Michoacán did the same with all the clerics who hold a prebend in his diocese. The Bishops of Havana and Santiago de Cuba and others including the viceroy himself, the Marqués of Mancera and his wife the Condesa de Orizaba, and other nobles and gentlemen in addition to many convents have done the same.

[3] Favián sends one hundred prayer books so that Kircher can distribute them to those who might be interested and devoted to Christ. He asks Kircher to distribute them also to persons like princes and cardinals who would then be able to expand the reach of the confraternity in those parts, for if it became known that the Holy Father also prayed the hours from Favián's book, then it would lend great authority to the work which he had produced. Favián has sent a finely bound volume of the prayer book for the pope; ${ }^{171}$ it has gold and silver corners. Next Favián asks that the pope select a day of the year when the confraternity will pray for him. There are also six copies of a smaller work produced by Father Pellegrín which is a collection of dialogues related to the confraternity; Favián intended to produce it himself but ran out of time due to all the preoccupations he has had recently.

[4] Favián asks Kircher to request that the pope offer a blessing for all those who join the confraternity so that it will inspire the doubtful and lead them to spiritual benefits. Favián mentions a new correspondent, the Archbishop of Manila, Miguel de Poblete, and the gifts

\footnotetext{
${ }^{170}$ The title of this new religious confraternity is: "La Hermandad y Santa Cofradía del Amor Perpetuo de Christo."

${ }^{171}$ Note that Favián has had his book printed and finely bound in Puebla.
} 
which Favián is sending this friend on the next Manila galleon. Favián is sending materials to friends in distant places for the establishment of the confraternity with a director and a deputy; he asks Kircher to be the one of these for the city of Rome.

[5] Favián states that his friends have asked him to tell Kircher about a recent occurrence concerning the religious artwork which he had made especially for the chapel where he resides, and which will house the other clerical members of his brotherhood. The image includes Christ in a purple tunic with the cross on his way to Calvary. Favián commissioned this painting to reflect Pope Urban VIII's decree about the correct depiction of Christ on his way to Calvary as explained by the theologian Quintana Dueñas and others. Contrary to popular depictions of Christ in a loin cloth which show him distressed and in agony, this papally sanctioned image shows Christ's equanimity.

[6] Favián is dismayed that there are religious works of art in Mexico City which do not conform to the papal bull which was issued a few years prior.
[7] Favián decided to inform the Office of the Inquisition in Mexico City about how the artworks in his chapels conform to the correct aesthetics while there are others in Mexico City which do not. ${ }^{172}$

[8] Favián sent Fernando de Comparan to the Holy Office in Mexico City to deliver his letters. They received them enthusiastically and offered Favián a position as consultor primario, ${ }^{173}$ but Favián declined the honor because he felt that it was a post for experts. Favián has included the actual letter from the Holy Office of Mexico for Kircher to see it.

[9] Favián's friends have asked him to include more accounts of praiseworthy challenges which he has successfully overcome but he has excused himself from doing so by saying that he does not want to tire his reader. ${ }^{174}$

[Signed 12 March 1666]

APUG. Vol. 565 EPISTOLARIO KIRCHER XI, Fols. 154r-157r.

\footnotetext{
${ }^{172}$ Whether or not Favián has been to Mexico City recently is not clear; he may have heard about the artwork styles from an artisan who had been there and then written a letter to the Office of the Inquisition. It is puzzling that Favián never mentions personally visiting the capital when it was only a day's travel away and may have facilitated the professional contacts which he needed for achieving his career goals.

${ }^{173}$ The Mexican Inquisition was often short staffed and appears to have invited Favián to take on the title of an official functionary whose focus would be matters of religious art. This office job does not interest Favián, but he does use the Inquisition's letter as a way to demonstrate his merits to Kircher. ${ }^{174}$ What follows in the manuscript is a note of praise from the Mexican Inquisition for Favián.
} 
Letter 7 Summary ${ }^{175}$

To Athanasius Kircher

From Alexandro Favián, March 1666

A list of the contents of a large box one vara and a half in length, wrapped in leather and sent to Kircher for: Kircher; Pope Alexander VII; the emperor; Cardenal Chigi; the Jesuit Father General Paulo Oliva; and for the Rector of the Colegio Romano.

For the pope: a cross from China made of distinctive wood, embellished with mother-ofpearl, for his oratory or chapel, which comes from the Archbishop of Manila. A cup and saucer made of Mexican marble, tecal, embellished in gold and with silver handles.

For Cardinal Chigi: a few animals and some seeds, as well as a feather portrait of Our Lady. Also, a small chest, made also of the local marble, tecal, which has a lock and key in black and gold; also, two fine porcelain cups from China with their lids, for keeping vinegar and olive oil. One more fine China cup with a lid, gilded, a glass with matching white, marble plate. A holy water bowl made of black marble and adorned with gold.

For Emperor Leopold Ignatius: Favián writes, "For the August Majesty of the Emperor, I send an open letter so that Your Reverence may read it before sending it to him and with the marvel of a feather portrait that I have so many times mentioned to you and which is so grand and beautiful that all who have seen it say that nothing more precious and admirable has been made here." Favián also sends a letter from the Canon Sebastián de Pedroza y Zúñiga, the priest of Pátzcuaro who contracted ten master artisans who worked on it continuously over three months and who spent 150 pesos de ocho for the artists' salaries plus their meals and other costs in addition to the price of transporting it here. He says: "there was a gentleman here who offered 500 pesos for it perhaps in order to send it to the King in Spain. Here people have been coming daily to marvel at it. Your Reverence should see it and all of Rome should marvel at its artistry." Favián also sends a very precious marble cup, painted in gold filigree with silver with large silver handles and inside a deer's bezoar stone decorated in the same way. He notes: "Bezoars are thought to be very beneficial here and are put into cups used for drinking water and wine. There have been experiments attributing benefits to doing so." $\mathrm{He}$ also sends the emperor a small goblet of white marble, with a closure, key, and decorations all gilded. The closure bears the imperial eagle and distinguishes it from the other one which is intended for Cardinal Chigi whose marble goblet is smaller and decorated in gold and black. They are for holding holy water. Favián ends this section by saying: "These two gifts I

\footnotetext{
${ }^{175}$ Letter 7 is an itemized list of gifts which Favián is sending to Kircher. Favián has chosen decorative religious artifacts which he considered to be unique and beautifully crafted. The list is divided into sections in order to identify the gifts and letters for each person including Pope Alexander VII, Cardinal Chigi, and Emperor Leopold I.
} 
send to the emperor, the about the said cup and chest with the gilded decorations, I leave it to Your Reverence to decide, so that if it seemed sufficient to not send the items, in particular the cup, you may feel free to do so. Likewise, if it were not necessary to ask the emperor to communicate with the King of Spain but rather through His Holiness or Cardinal Chigi, Your Reverence may choose whichever method is simplest or most expedient. To the Emperor, I send the feathered portrait, which is prodigious and admirable, but if the emperor will need to communicate with the King of Spain... [Manuscript pages are missing.] $]^{176}$

APUG. Vol. 565 EPISTOLARIO KIRCHER XI, Fols.160v.-161v.

\section{Letter 8}

Father Athanasius Kircher,

My Reverend Father and my only Refuge of Hope:

[1] With the ships of the fleet that have left this kingdom for Spain in May of this year, 1666, I sent Your Reverence three boxes, with as much chocolate as there were other varied and precious, beautiful, and curious items in the possession of my correspondent Señor Francisco María Tassara. He also had for delivery to Your Reverence a large folder of letters and other matters of mine which, if God is willing, will reach your hands; may they be the remedy for all my troubles, concerns, and afflictions. Once they arrive, just in case one of them were to not make it, there is a duplicate copy as well and Your Reverence will have already seen all that they contain and what has been the local pronouncement on this matter, which I protest here again a thousand times over before the Majesty of God, whose presence I am in and to whom I have as a witness, and His most blessed mother, that the proposal for me to become a bishop was not born of my pretense, nor has it ever crossed my mind, and never in my life have I desired to have any dignity or honor. But rather it has been many serious and learned persons of the clerical and religious state, canons, doctors, prelates, provincials, rectors, priors, comendadores, as have other persons such as caballeros, governors, judges, and the entire town who have persuaded me in una voce clamantes et dicentes. ${ }^{177}$

[2] But oh, by my Lord and God, I tell you, with all my heart, that I do not know what good in me these persons see or have seen? What virtue, prayers, or penitence? What perfection? Which examples? What charity? And not the least of all, what holiness have they found in me? As these are all necessary for such an important status, such as to oblige me, nay force me to impose on Your Reverence with such a great and important endeavor, o Deus meus, qui

\footnotetext{
${ }^{176}$ Favián appears to be asking Kircher to decide whether to send some of the gifts to the emperor or to the king of Spain, depending on which approach Kircher believes will expedite Favián's request for a bishopric.

177 "Crying out together as one."
} 
scrutas renes et corda, nescis Domini quod non mentior $^{178}$ and since I am not gifted enough to truly fulfill the tasks of a bishop, I find myself worried and afflicted, without knowing what I have gotten into, but if it is your most holy will, my dear Lord God, fiat sicut tu vis, que si populo tuo sum necessarius, non recuso laborem quamvis indignus ac indignissimus et pecator miserabilissimus. ${ }^{179}$

[3] I would like, as I find my innermost self, to write to Your Reverence and to ask you not to proceed in advancing my proposal, ${ }^{180}$ which is true and I protest with tears from my eyes that I am very wicked and that there is nothing good in me, but the misfortune is that now even if we wanted to intercept the petitions, it is no longer possible for me, Your Reverence, or the Reverend Father General because since everyone here found out that I had written clearly to Your Reverence about it, they have learned how certain and simple it would be to obtain it due to Your Reverence's great influence and due to how many important connections you have for achieving this through our Queen in Spain; as you also do with our Emperor, brother to our Queen, whose feather portrait I sent to you for him; these connections have been judged most expedient and swift, because he would ask his sister, and she would not refuse him. This is how it was explained to me, excitedly, by the bishop of this city, speaking little of this topic with me; it seemed to him much simpler to achieve this now that the king has died ${ }^{181}$ since the Emperor would write his sister with more familiarity and ease, rather than to his brother-in-law the king, because I had petitioned Your Reverence to recommend me to His Holiness for the said bishopric in Michoacán for the future succession if Don Fray Marcos Ramírez, who governs it today, were to pass on. If the position were not available there, then that my petition may apply to any opening which might present itself in the Indies or in some other part of Spain, or Peru, even if the location were very short of funds, as the best ones here are not vacant at the moment. Later, with Your Reverence's assistance, it will be much simpler to have me promoted to a larger and better bishopric. What matters most right now is to put me in that role, since later Your Reverence will easily move me to another, since it is more valuable to be a minor bishop than a wealthy prebendary, ${ }^{182}$ because there are prebend positions in the Indies that have higher stipends than some of the bishoprics. That is how I feel about it as well, since regardless of where it is, even if it is poor and weak in rents and jurisdiction, it will be a very good start, since

\footnotetext{
178 "Oh, my God, who knows the hearts and minds of men, I do not lie that I do not know."

${ }^{179}$ Favián appears to be praying in this section: "Let it be as You wish, if Your people need it, I will labor for it, though I am utterly unworthy and a sinner."

${ }^{180}$ Kircher must have been uncertain what Favián actually wanted him to do from this point on: Favián changes his mind several times about whether or not he would like Kircher to proceed with presenting the petitions in favor of Favián's appointment to a bishopric.

${ }^{181}$ Philip IV of Spain died 17 September 1665, nearly a year before Favián wrote this letter.

${ }^{182}$ A cleric attached to a particular church and whose stipend, or regular income, comes from the donations made to that church.
} 
one of those will be more valuable than a wealthier dignity of some kind although it is true that there are some bishoprics that are so impoverished and remote that the role of bishop, priest, and sacristan are all the same person and there is not even anyone to converse with other than the uneducated and barbaric peoples. This I heard happened to a bishop to whom the King of Spain gave a dispensation for him to walk among the residents in secular clothing, without a cassock or episcopal robes, and that in such a manner he would enter the poor dwellings of the indios and mulatos in order to chat with them. He described the capital city of his great archdiocese as nothing more than some solitary hills with fifteen or twenty little straw homes inhabited by uneducated mulatos and barbarous indios; and he said that there was no other hombre blanco than one other clergyman who was the parish priest and the sacristan. In his church there was little more than an altar and a chasuble, a writing table without a clock, ${ }^{183}$ and a jacal where he lived, which is a single room made of straw, for which the King, seeing such great misery promoted him to a greater bishopric; some of those can be found around here. There are medium-sized bishoprics with a good living such as Guatemala, Oaxaca, Chiapas, and Michoacán; better bishoprics, large or distinguished ones, include our own here in Puebla and the archdiocese of Mexico City which are the two principal cities in this kingdom. There are also some moderate bishoprics in China ${ }^{184}$ and it is in the other kingdom, Peru, where there are many large and illustrious bishoprics. I have heard that it is a very beautiful kingdom, and I would gladly go there. ${ }^{185}$ And so, if there were not a place in Michoacán, it would be good to ask to be sent there because here at present, there are no vacancies that I know of other than Mexico City and Honduras. I have mentioned this to Your Reverence because of our bishop and many others who have instructed me to write you and to let you know so that, regardless, I may reach this position because it would in this way be a credit to us ${ }^{186}$ and to la nación de los criollos indianos, ${ }^{187}$ even if I were posted wherever, or anywhere, according to the fortune decided by God's plan; all of them have made me hopeful

\footnotetext{
${ }^{183}$ A table lacking a clock is an interesting detail; Favián has discussed clock maintenance as a hobby in earlier letters.

${ }^{184}$ This term appears to refer to any place in East Asia where the Jesuits, Dominicans, and Franciscans established missions. The Philippines had the most bishoprics and, during a period of five decades some parts of Japan had missions. In China, the number of conversions remained modest, and were mainly in Beijing and Macau.

${ }^{185}$ This is another interesting remark in light of Favián's earlier humility discourse; at this point Favián envisions himself in the more splendid bishoprics.

${ }^{186}$ Favián gives the impression of being compelled to write by his superiors.

${ }^{187}$ Here Favián states a political identity: his own personal career advancements represent that of all criollos (the sons of Europeans in New Spain). The implication is that if Favián is able to rise through the ranks of power in New Spain, then other criollos will also. His choice of phrasing is wonderfully suggestive because it shows that Favián is not only thinking of himself; he is thinking politically and aspires to be among the first of his social class to become a bishop. With the help of Kircher, he is attempting to bring about change in the politics and clerical hierarchy of the Spanish colonies.
} 
and looking forward to what this could mean in a few years. ${ }^{188}$

[4] The other requirement is a dictum which can be taken care of with only a recommendation from his Excellency Señor Cardinal Chigi to the Queen of Spain; ${ }^{189}$ not only would it be sufficient, but it would be more than enough for such a great señor as the nephew to his Holiness, such a matter as this, which lesser men have been granted ${ }^{190}$ would not be denied. We have seen this happen, not once but many times, in the past when with little more than a word from the viceroys on behalf of someone, whether it was a clergyman or a friar from this kingdom, upon the viceroy's return to Spain, and within a year or two the said are provided with very good bishoprics.

[5] Beyond all this that I have said, they, the priests of the Jesuit Colegio del Espíritu Santo, as well as others, and the whole town, believe that my appointment to the episcopate would be very easy to achieve because they believe without a doubt that I am related to the Reverend Father General Joan Paolo Oliva since my grandfather, Joan Baptista Oliva is known to this entire realm and everyone knows that my lineage traces itself to Genoa. ${ }^{191}$ And so through Christopher Columbus who gained these lands, as through the Olivas, and there have been many in my family with that last name, there is no doubt that his Paternal Reverence is very influential with His Holiness as with the monarchs of the world, and more so now, for I have been told that His Holiness is planning to make him a cardinal.

[6] Others, taking a different line of thought, consider it already done, with great expedience, because, you see, here in these kingdoms we have heard that since our Queen has a Jesuit

\footnotetext{
${ }^{188}$ The final sentence of this section explains that Favián felt he was the hope for other men, who were born and educated in the Americas like himself, to rise through the ranks of the hierarchy. At this time bishops for the Spanish colonies were nearly always European clergymen appointed in Spain. Bishops also held significant political influence outside the pulpit; one of the most important roles that a bishop in New Spain or Peru had access to was becoming interim viceroy as the voyage to or from Spain caused delays between the departure of one viceroy and the arrival of the next. A bishop would likely have had other kinds of political influence which criollos could also not access. It is no wonder that Favián states that he has the encouragement of many persons, many were undoubtedly criollos themselves. Had he succeeded, he might have ushered in a new age for criollo clergymen 150 years before independence from Spain when criollos did become the most powerful members of Mexican society. Before Independence, criollo bishops were a rare occurrence, the two best known were born in the early years of colonization, Fernando de Trexo y Sanabria Bishop of Córdoba del Tucumán 1594-1614 and Alfonso de la Mota y Escobar Bishop of Puebla 1607-1625, but their appointment appears to have taken place at extraordinary moments, and the perception among colonial-era criollos was that they were overlooked for promotion in political offices.

${ }^{189}$ A later letter from Rome explains that this approach was attempted, but the Queen of Spain had retired from political activities and put her confessor, to whom she had given explicit orders not to take recommendations for episcopal appointments, in her place.

${ }^{190}$ Favián reminds Kircher, more than once, that lesser men than Favián have been appointed to the role of bishop in the past.

${ }^{191}$ Everyone but Favián seems to be certain of this fact.
} 
confessor who was brought from Germany ${ }^{192}$ and who is greatly respected and is entrusted for his prudence and conscientiousness with the child king, as with all the governance of the kingdoms of Spain. And so, with letters from Your Reverence and from the Reverend Father General there is nothing, great as it may be, which is beyond reach because the Queen surely would not deny requests by the supreme prelate and Your Reverence, esteemed as you are throughout the world. This which I write is so certain that our friend Francisco Ximénez recently wrote it to me in a letter from Mexico City in nearly the same words. In it, he advised me to not hope for a clerical benefice in these kingdoms having to do with indios and their administration because these positions are very distressing, difficult, and laborious to achieve by way of the viceroys who make the appointments by way of royal patronage. And that it would be much simpler to achieve a bishopric with the help of Your Reverence, even if it might be one of the small ones because none of the others are vacant at present, or if this was not to be, it could be some form of ecclesiastical dignity such as a deanato ${ }^{193}$ which will become vacant in Puebla due to the great age of the current one and his aches and pains. Otherwise, the archdeaconship of the same church which is presently vacant due to the death of Doctor Domingo de los Ríos, my friend, who is one of the gentlemen with a prebend who has encouraged me to seek out various positions including those of treasurer, cantor, and maestrescuelas for any church which happens to have one of those dignities available; in Spain this information is known, but in the unlikely event that none are vacant right now then that I should try a post as a canon ${ }^{194}$ here in Puebla or in Mexico City. Or as a last resort, according to my friend, with a simple letter from Your Reverence to the Queen's German confessor so that he could ask her for my appointment to a post by saying that it would please the Reverend Father General of the Jesuit order if his Reverence would like to do me the favor of writing on my behalf also. My friend said that he did not doubt that anything which were asked for specifically, regardless of how great it might be, would be granted with ease and speed without the loss of time. This too was what Father Ximénez indicated, to him I owe much benevolence, duty, and friendship; he feels pity seeing me in such a sad state, as I am poor without my former

\footnotetext{
192 Juan Everardo Nithard (1607-1681) was the Jesuit confessor to the Queen Mariana de Austria and another contemporary of Kircher's. He had traveled from Austria with Mariana to Madrid from the time of her marriage to her uncle, Philip IV, in 1649. Everardo Nithard was very influential in politics during the Queen's regency for Charles II from 1665, at least until 1669 when the confessor was dismissed by the illegitimate son of Phillip IV, Don Juan José de Austria.

193 The "deán" in Puebla was the canon (ecclesiastical member of a council) who led the cathedral council. Generally, this position was held by a priest whose role was to assist a bishop.

${ }^{194}$ A canon was an ordained priest who was also a member of the cathedral administrative council. There were general canons as well as specialized roles; one which Favián would perhaps have been most easily recommended for would have been the council's official confessor, a canónigo penitenciario.
} 
self-sufficiency and was once able to assist others in their times of financial distress.

[7] All of the above, which I have summarized in order to not tire Your Reverence is here, in this kingdom, already considered to be certain and approved that no one doubts that it will come to pass through the will of God and Your Reverence's sponsorship and assistance.

[8] These then are the reasons, oh father and señor of mine, why I have decided not to abandon what is already begun despite my inadequacy, doing so might bring our praiseworthy correspondence into disrepute in these lands. If I gave up now it could be misinterpreted by malevolent persons to be a sign that our friends were not as influential as we claimed and that our letters were untrue, and that I have fabricated these matters, that it has all been an illusion. I especially do not want to give up because a few days ago, while speaking to my bishop of Puebla in order to give him the papers regarding one of the priests in my congregation, the bishop said in the presence of Father Pedro de Valencia, the rector of the Jesuit Colegio de Espíritu Santo, who is also my very much my friend and has always given his approval and letters of recommendation saying that I am a very good choice for the roles, and so I am very grateful to him. The bishop used many words of praise to describe me in the presence of the said father rector and other señores.

[9] In addition to this, as I have already written to Your Reverence and also to our Father
Ximénez in Mexico City, about the principal reason for my supplications and requests for your sponsorship in helping me to achieve the proposed or any other prebend, being that I currently find myself so poor and without a source of income since spending my inheritance with such determination and persistence in the name of Christ and holy acts of piety that I have left myself with nothing, so much so that I can no longer live in the way that I was accustomed. And I only seek a position in order to better serve Your Reverence and to be able to send the gifts which I would like to do more so than for my own comforts, because I find myself in such a state of obligation and debt that my goal is to send payments for the many honors, true loyalty, and great generosity that you have honored me. In order to not miss the chance to reply to Your Reverence's letter, I spent 1,300 pesos in sending the package; this was the last of my funds for living on and even though I am left perishing for lack them, I regard them as well spent because, as I have already said this is how much I esteem and value Your Reverence whom, even if I needed to beg door-to-door for alms, I would give all that I had in order to serve Your Reverence with it even if it were little, because neither the troubles, poverty, concerns, worries, afflictions, disillusionment nor the great costs and expenses that are necessary for the maintenance of our correspondence, even if I were even further away in a more remote land than the one where I am, and not even on death itself do I think, which would be together more than enough to distract me from remembering Your Reverence. And so, in the same way, I believe and am very certain that Your 
Reverence will not forget about showing me favor and looking after me now that I am in such need of a post, as I am resigned to placing my worries in God's hands and leaving it all in the hands of Your Reverence so that between the one and the other what is best will come to me. Amen sic fiat, fiat sic Deus voluerit, amen. ${ }^{195}$ And may he look after Your Reverence as my only shelter, relief, patron, and remedy, with happy and long years of health and the life which I and the whole world need for your fame and honor. Farewell. ${ }^{196}$

City of the Angels, 2 August 1666.

Don Alexandro Favián, presbyter. ${ }^{197}$

[10] There is money to pay for the helioscope is in one of the drawers at the price which Your Reverence mentioned in the last letter and again in this one which has the dispensation for the priest in my congregation although I do not remember whether the 50 escudos that it must cost are correct because no one here knows how many Spanish reales make a Roman escudo, although I think it takes 10 . If by chance, the amount is incorrect do not let that prevent you from purchasing the best available instrument with notations; if you could loan me the difference, I will send the remaining amount with the utmost haste along with a little gift of chocolate. And may it be packed in such a way as to not be damaged.
[11] Here I have already purchased a portable desk made of linaloe wood from Oaxaca in order to send it to Your Reverence on the next fleet, so that you can use it to store your writings and papers. It is a most rare item because it has drawings inside and out of exotic figures, idols, and hieroglyphs from the hands of the indios, very similar to how Your Reverence drew them in your Oedipo egiptiaco, something which impressed me when I saw it, so I decided to purchase it immediately even though the vendor asked 20 pesos for it. It was like a prize that came to me; as everyone knows of our correspondence and that I seek good quality and curious items to send to Rome, vendors come to my door each day to offer singular items. It is painful to not be able to purchase them for lack of funds, and I turn them away with feelings of remorse; but this is how this gift came to me, a most admirable and wonderful item.

[12] I have written to my correspondent, Francisco María in Spain, or Genoa, wherever he happens to be, a request that Your Reverence be paid however much is necessary for the paperwork necessary for me to be able to be appointed in Spain, if God is willing, to the bishopric of Michoacán that I proposed or to any other in any of the kingdoms. This way everything can come at the same time from Spain and Rome, and we will not lose time, or

195 "Amen so be it, let it be as God wills. Amen."

${ }^{196}$ Favián's farewell sounds rather final, as if he were ending their correspondence because he is short on cash or he is expecting one of them to pass on before he has the new funds which he would need in order to be able to pay courier's fees and sending packages overseas.

${ }^{197}$ What follows is a postscript. 
whichever way that Your Reverence might think is best.

APUG. Vol. 564 EPISTOLARIO KIRCHER

X, Fols. 21r-22v.

\section{Letter 9 Summary}

To Athanasius Kircher

From Alexandro Favián, 20 April 1667

Favián is very thankful to Kircher for his last letter full of kindness and encouragement. Favián is going through difficulties: "at present I find myself so afflicted and disconsolate, so forlorn and helpless in the land where I was born and where I have worked for so many years without attainments or appreciation." His finances are dwindling because he says things have become more difficult and he has experienced losses to the family's treasury. $\mathrm{He}$ claims that his only source of comfort is sending Kircher some kind of gift. He describes his sleeplessness and tears over the prospects of having asked Kircher to help him to obtain a bishopric: "I only wish that I had a corner in a hermit's cell or in the desert, a cave where I could hide and live in solitude and retreat, and where I can do penance for my great sins." $\mathrm{He}$ asks for God's will to be done regarding his future clerical appointment. In closing he mentions two of his friends, Nicolas de Pantoja, regional vicar of the Dominican convent in Puebla, and Raphael de Estrada, a childhood friend who, like the vicar, holds the clerical title of a provincial. Favián concludes by praying for Kircher to live many happy and fortunate years with physical and spiritual health.

\section{APUG. Vol. 559 EPISTOLARIO KIRCHER V, Fols. 9r-10r.}

\section{Letter 10}

To Athanasius Kircher,

Most Wise and Beloved Father:

[1] The crate that Your Reverence sent me from Rome by way of my correspondent Francisco María Tassara, arrived in this city of Puebla today, the day of Saint Borromeo ${ }^{198}$ a saint to whom I am especially devoted. I received it later than expected due to major delays with delivering it to me. This may have been due to an absence of the usual linen covering or some other wrapping. The crate also lacked any kind of ties, tethers, or cords and simply had bare wooden planks. In the spot where the label, my name and the crate's destination are usually identified, the word "fideos" appears, on both sides of the crate. ${ }^{199}$ Seeking to do proper

\footnotetext{
${ }^{198}$ Carlos Borromeo (1538-1584), Cardinal of Milan, was canonized in 1610 as the patron saint of seminarians and catechists with a feast day of 4 November. When Favián mentions the saints' feast days it is a way of indicating the date and also of linking it to a well-known saint's story which has meaning for him.

${ }^{199}$ A box with the word "fideos" on it would have been used to transport dry pasta; Favián finds this crate odd and suspects that it is not the one which Kircher sent. He is suggesting his fear, which he
} 
diligence, I learned from one of the mule drivers who had brought it all the way from the Port of Veracruz to Francisco María's home in this city, that the crate had been opened and that he, the mule driver, had closed and nailed it. Under these exceptional circumstances, I did not want to receive it without witnesses, so Señor Geronimo Gallesio, also from Genoa, was the principal witness; he was also the person from whom I accepted the crate. I cannot be entirely sure about whether the contents are complete or precisely what is missing because I have thus far not yet received a memoria ${ }^{200}$ of the contents nor have I received any letters from Your Reverence or from any of the señores and friends who have granted me so many honors. Neither have I received one from María Tassara, my correspondent, who had promised to send one. I was under the impression that since he would not be coming to Puebla this time, because he is in Rome, that the accompanying letters would be inside the crate. To my surprise, I did not find letters of any kind, nor the official seal pertaining to the box of relics which I believe the reverend Father General has sent; likewise, I think that many other things are missing, most importantly, among the books I see that some of those that I was expecting are not present. For that reason, I would like now to make a list of all that I have received. Your Reverence will thus be able to compare it with what you sent and can let me know what should have arrived.

[2] Of the copies of your new work Obelisco, one came for me, a second for the archbishop of Mexico City, and a third for our mutual friend, Father Francisco Ximénez.

[3] Regarding the copies of the Arithmología, they are the same edition as my own. There are thirty-two, ${ }^{201}$ three of which are bound, mine plus one for the bishop of Puebla and the other one for the archbishop of Mexico.

[4] The Mundo subterráneo arrived in one volume. According to Your Reverence's list of books, which was slipped into the Obelisco nuevo, I gather that the Historia de San Eustachio, and the work about China, because they were both printed at the same time as the two previous titles, were meant to have been included. I believe this may have been your intention because some loose pages of these works are present in the crate. ${ }^{202}$ Additionally, I am persuaded that the four parts of Gaspar Schott's Magia along with his Curso mathemático, which in years past Your Reverence has indicated would be sent to me on the earliest crossing of the fleets, ought to have

elaborates on later, about some items having been stolen or removed at one of the many inspection points.

${ }^{200}$ In this context of early modern shipping, a "memoria" is a list of items; here, it refers to book titles for port officials to keep track of what is being transported.

${ }^{201}$ This appears to be a classroom set of textbooks for teaching.

${ }^{202}$ It is unclear whether these loose pages have been torn out in haste by thieves, whether they fell out of a loose binding by accident, or they were sent by Kircher on their own. Later in the letter we see that these loose pages give Favián a creative idea about how he can use scraps or "offprints" from Kircher's books to produce some sort of collage display. 
been included as well. Thus, as these later publications have already arrived, I cannot imagine why the previously published texts would be left out since I indicated in earlier letters how much I desired the volumes of the Magia and how it would feel truly like death to be without any of Your Reverence's works even if it were only a page missing from any of them. I am saddened that there is no list of contents in this crate to consult. I also believe that someone must have removed a longdistance telescope of the kind which has four lenses that I asked Your Reverence to send because of the one that you sent the last time and which I have not received this time.

[5] I received the above mentioned books, and the helioscope, closed and sealed inside its box but without the machinery that should guide, lift and hold it in place. ${ }^{203}$ The parts are sorely missed as it is not possible to use the helioscope without them. ${ }^{204}$ It is not possible that the helioscope will work without its machinery and there is no engineer in these kingdoms who will be able to build it without having first seen one. ${ }^{205}$ There is a box of relics that the Father General sends but without its accompanying bulls or testimonios. ${ }^{206}$

[6] Another small box with its bull from his Excellency the Cardinal Chigi.

[7] Another, smaller one, also with its bull from the Dominican Superior General, Vannizan. ${ }^{207}$

[8] A box from the Father General with two bronze-gilded images, six large reliquaries made of buffalo horn, and a large box of the same material.

[9] A box of the same size containing agnus wax ovals ${ }^{208}$ and on top four small boxes: two painted from Your Reverence and one, gilded, from His Most Excellent Cardinal Chigi, which contains 48 or 50 small silver medals, with a very small box holding two pebbles; a squat

\footnotetext{
${ }^{203}$ Favián appears to be missing a tripod or other stand which would hold the instrument and the sheet of paper in place. He may be missing some of the indicators for making measurements as well.

${ }^{204}$ Perhaps if Favián had known how to devise a makeshift helioscope using a telescope as Galileo had done, he would have felt better equipped to make do with the parts that he had received. For a model showing how Galileo's helioscope worked, see: https://catalogue.museogalileo.it/multimedia/Helioscope.html

${ }^{205}$ Favián seems to indicate that he has not seen one before and by implication does not own any images of a helioscope; he might not have seen an illustration of the instrument in his books although he has clearly read or heard its mention. Interestingly, Kircher and Christoph Scheiner (1573-1650) co-authored Mundus subterraneus (1664), and Scheiner was an expert on helioscopes. The 960-page work includes drawings of machines and scientific instruments, tables, diagrams, and other general illustrations including an impressive one of the Moon. https://archive.org/details/mundussubterrane00unse/page/n948/mode/thumb

${ }^{206}$ Bulls could be documents produced in the Vatican or simply the official seal used at the end of these documents. "Testimonios" would, similarly, have been formal statements from an official or documents attesting to the official status of a blessed relic.

${ }^{207}$ This may be a variant of the name "Veneziano" or "Giovanni."

${ }^{208}$ Small, pendant sized, devotional item, often showing a paschal lamb and banner, made from the previous year's Easter candle, and infused with a scented baptismal balsam.
} 
little box with stones mounted in wax and a large medal with the image of his Holiness the Pope, may he be with God in his glory, in addition to a decorated panel with the impression of the new saint, Francis of Sales, ${ }^{209}$ painted in silver on mother-of-pearl. Another of the same kind from Señor Conde Juan Federico de Waldstein, papal chamberlain, who without my having served him in any way has deigned to honor me, his humble servant, with such a gift that has so many and such precious stones, that I am not sure what they can possibly be nor what purpose they are intended for. ${ }^{210}$

[10] Also a box from Your Reverence with rosaries, some relics and rings made of buffalo horn, and two risquitos ${ }^{211}$ in the shape of books.

[11] Also a longer box with a curious, smooth, wooden cup and a small white box with a curiosity from Germany, with small baskets for my museum and stones and metals from the mines which I do not know what to make of.

[12] Also a rounded box containing a rounded vessel with its lid made of a curious and delicate material. And a small bowl with its rim of the same material.

[13] A special container has arrived with the bones of saints and a bonnet of the kind that the most holy Virgin of Loreto wears on her head, which I presume was sent from Loreto by Francisco María Tassara, my correspondent.

[14] This is in sum, all that came in the said box and that I have received, for which I remain eternally grateful. And so, I write this inventory in order that Your Reverence may know and communicate to me about whether anything else was sent. That way I will be able to perform due diligence and charge those who opened the box, which truly, if it had been properly sealed with tar as well as an interior lining, they would not have opened it, but once removed the items may as well be considered lost. If by chance, Your Reverence was not able to send the missing books, may this letter simply be a notice of what I have received. I humbly ask that Your Reverence not neglect to send the other books at your earliest convenience, principally the Magia volumes by G. Schott, Your Reverence's works, and the one about China. And if your Course in Mathematics ${ }^{212}$ were already in print as well as any others which Your Reverence may have published, because all of your books bring me delight, relief, and entertainment as if they were written specifically for me and also because I need them for the treatise that I have proposed, based upon the works of Your Reverence and others of mine which I already have available. Here is the title page of the work, which will contain

\footnotetext{
${ }^{209}$ Born in the Duchy of Savoy (1567-1622), he was canonized a saint in 1665.

${ }^{210}$ Favián does not seem to think of these "precious stones" as being artifacts for his museum; he sounds underwhelmed and slightly confused about how to respond. They may have been a token of thanks for one of the gifts which Favián had sent to Rome.

${ }^{211}$ Unknown object, possibly decorative paperweights, or a pair of bookends.

${ }^{212}$ Kircher's Organum mathematicum, as edited by Gaspar Schott, was published in 1668
} 
five or six folio volumes, so that Your Reverence can see what it is about and can send a blessing and license, that in my lack of wisdom, I may dare to tap the great knowledge found in your writings and return all that I will derive from them. All my works are in the Spanish language, as it is my strength when writing, firstly because in these kingdoms, Latin is not used, and secondly, because even among regular clerics, ${ }^{213}$ not all read Latin and none of the secular ${ }^{214}$ priests do unless it is specifically a well-known phrase and in which case that is only because it is necessary to know it or because they are doctors, canonists, or in similar roles.

[15] And additionally, please let me know how much it will cost for each folio volume of 300 sheets each, which will be 600 pages, more or less, with the title page at the start of each volume and some images and figures as illustrations which will be the book's strength; just like the ones that Your Reverence includes, although somewhat changed, such as the ones that I will send which will all be drawn in pen so that fine and beautiful copperplate etchings can be made using the drawings as models for printing. And likewise, if you could inform me of how many imprints of a book are typically made, whether 500,800 , or 1,000 as well as the costs for each at the Jansonius publishing house in Amsterdam which would add interest. ${ }^{215}$ Likewise for printing in Rome and whether that could be achieved more economically; I will find out if it would be more convenient to it send to Spain for printing. They will be foliosized works, similar to all the others which, with the grace of God and Your Reverence's help, I hope to bring to light. The volumes ought to come already bound. I would be grateful for information about these things as well as notice about the other matters at your earliest convenience so that I might send one of the volumes of the Tautologia, which is the first that I have nearly finished, along with whatever amount of money, of which you will advise me. The volume will be dedicated, along with the completed work, to Your Reverence in gratitude for the honor that you have done me by dedicating the work that you have sent me, Magnético reino, to this humble man. Five or six volumes seem to me to be the length that the work will fill. ${ }^{216}$ I will be able to cover the costs and pay for it all myself if God, Our Lord, were to grant me some part of what Your Reverence has endeavored on my behalf. Not only will I be able to finish with this but with all that I owe Your Reverence; I will be able to offer my

\footnotetext{
${ }^{213}$ Members of a religious order such as the Jesuits, Dominicans, Franciscans are sometimes referred to as "regular clerics" because they live according to the regulae, or rules and charisms, of their particular order.

${ }^{214}$ Secular clerics are those who are not members of a religious order and who thereby answer to the local bishop. Clerics are either "regular" or "secular."

${ }^{215}$ Favián uses the word "curiosidad" here and seems to indicate that publishing in Amsterdam will add value to his publication because of its high-quality publications which he has alluded to in the past and also because of its distance from New Spain - a kind of reverse exoticization.

${ }^{216}$ Favián speaks of writing volumes as if he were estimating how many containers he could fill with text.
} 
service in all ways possible as one ought to offer to a patron.

[16] On account of not having the books such as Magia and the others by Your Reverence, it has not been possible for me to continue with my Tautologia, because I need those works in order to complete it. And so, in the interim, while you send the rest to me along with any others that might be related to my vast and extensive book, I will attempt a minor work for my free moments, to fill the time and to aid in my digestion of the material in its precise details. This minor work has turned out to be so interesting, fleeting, and abundant, that even though I have been summarizing as I've been able to, I foresee six quarto volumes or three folio volumes. I have already finished one with its drawings, also one of 250 pages, more or less. I did it in almost 3 months, without having to write all day long, and God willing, while I await notice from Europe, I will complete another two volumes in which case I may send them as well. Therefore, it matters to me to know what it might cost to have one of these, with copperplate illustrations, fine ones although not many, printed. These might well be ready sooner than the large ones, since I cannot continue with those, as I have mentioned before, until Your Reverence does me the kindness of sending your works and those of Father Gaspar Schott, which are so important to me. One of my works, a quarto, which will be the first, I would like to dedicate to the most excellent sir. The second volume to my Father General Joan Paulo Oliva. The third to the Count of Waldenstein who has honored me and favored me as one of his own; and the others, I believe it will be convenient to dedicate them to those whom Your Reverence thinks it is convenient and whose name you will let me know. Or if not the first of them, another large one, to the emperor, the second volume to our Queen, the third to the Cardinal, the fourth to the Conde, the fifth to our Father General and all of the quartos to Your Reverence. I am without preference, and so await your advice on what you want me to do whatever that may be.

[17] My disconsolation over not receiving the letters is very great, as I do not know where Francisco María could have taken them, and since I have not received them with my own hands, I have said Masses and had many of them said so that God may be served by the great desire that I have to find out what Your Reverence will advise me regarding these matters and how it seemed to you, whether you judge it to be convenient to persist until achieving it; or if, at least, you will not refrain from obtaining a prebend for the interim that is more at hand in this church, the one in Mexico City or something for any other church, that whichever it might be, I would go willingly, as something is better than nothing. In the first place to not see myself so impoverished in my own patria, where I was born, without status or an official post. And secondly, to be able to meet my obligations to Your Reverence and to the other señores and friends, for the many gifts, honors, and favors that they have granted me; because if I must tell the truth, I feel embarrassed and disconcerted, or better put, very distressed to see myself so unable to 
respond in kind to such grand and powerful sirs; and more so when I see how close I am to being able to; lacking only many rents and monies, for I already possess in great abundance the will and desire. I ingenuously make God a witness to the truth with which I speak about how I would like to have the most abundant capacities and be among the most powerful of these kingdoms for the sole purpose of employing these things in the service of God and likewise Your Reverence with my gratitude, solicitude, and goodwill for all that I owe Your Reverence through my spirit, life, inheritance, and heart.

[18] It would give me infinite peace to hear what happened with the emperor, and whether letters on my behalf were given to his sister, the queen; or if something else was arranged some other way; and to know how the Reverend Father General, Cardinal Chigi, ${ }^{217}$ responded; because here in this kingdom, everyone has learned about it and they all take it as certain about this post, so much so that they cannot be convinced otherwise. Not a day or week goes by without someone coming to ask me about it. I do nothing but disillusion them of such thoughts, so that they will leave and not insist about it. And as much as I discourage them, they become more persistent, to the extent that I now attempt to hide the gifts and favors which have come from Europe, ${ }^{218}$ even hiding the precious items that I have received, such as what has been written, because those things have also inspired envy and emulation in many, perhaps even those who pretended to be excellent friends but were little more than false and ill-intentioned. Even with our bishop of Puebla, ${ }^{219}$ with the viceroy, who is the Marqués de Mancera, and with Father Ximénez, they procured to pro viribus ${ }^{220}$ discredit me by taking away a curato de indios ${ }^{221}$ that was going to be assigned to me in order that I might have an income for the rest of my life; and this is how I am now punished and frustrated by the matters and people of my country, and the greatest gift that Your Reverence could grant me would be to remove me from this situation. ${ }^{222}$ Thus the greatest gift which Your Reverence could do would be to find me a post in any land or kingdom whatsoever, because here I am not able to obtain anything, according to those who are possessed by imitation and Lucifer's envy. May our Lord, God command me and execute His will in the manner most suitable. And may He guide me, with all these most holy tokens and relics which have been sent to me by Your

\footnotetext{
${ }^{217}$ At the age of 26, Flavio Chigi was named cardinal-nephew, a position he held from 1657 until his death in 1693.

${ }^{218}$ Francisco Ximénez has by this point already sent Kircher letters wherein he depicts Favián uncharitably. In particular, Ximénez's interpretation of Favián's behaviors differ from Favián's explanation here.

${ }^{219}$ Diego Osorio de Escobar y Mendoza Llamas (1655-1673).

${ }^{220}$ Perhaps Favián means "ad hominem," as in a criticism of one's person rather than one's ideas.

${ }^{221}$ A clerical appointment at an indigenous parish.

${ }^{222}$ Favián is understandably concerned because of his damaged reputation and the loss of a friend in Ximénez. Other matters at stake include his sinecure, a desire to fulfill his vocation as a priest, and his personal commitment to repay debts to his friends, family, and possibly to the builders as they complete the renovations to his chapels.
} 
Reverence's hand, to wherever I can serve Him best. Because I know that in any location which might be available, and in any other church where I may take them, they will be better appreciated and solemnly valued than they are here since there are very reasonable bishoprics in this kingdom that have nothing like what we have here. They will probably be better esteemed there than they are here, where your gifts have not received much attention. ${ }^{223}$ But then, how could these be esteemed if in some churches as large as this one, there have been such utterly forgotten relics kept with such little decency that among these was found, after many years, a neglected and damaged bust of Pope Sixtus. It seems that they have found the rest of the bust, which I have faith that God will make me able to restore to all its due majesty and reverence wherever God may take both me and the holy items, with great solemnity, for by then I will have free reign to display them in my chosen manner and with my own salary. May Our Lord God do what is most appropriate with His infinite wisdom; He knows what will be best for His honor and the glory of these tokens of the saints which remain in my possession, for the spiritual good of all and for my betterment: these are my goals which I have always had without any personal motives or inconsistency. To the truth with which I speak of these matters, Our Lord, God is a witness, and I am continuously petitioning God through my sacrifices and prayer exercises that it ought not come to pass if it will prevent me from the virtue, perfection and zeal of a Saint Charles Borromeo $^{224}$ whom I have chosen for my patron saint for daily devotions in order to have him as my model and example. May God allow me to achieve this before my death, for quid proderit humani si mundum universum lucretur, animae vero suae detrim entum patiarus ${ }^{225}$ as Saint Paul wrote. And so, since for Your Reverence, God has chosen me as an instrument of this, I am pleading vehemently, that you may do that which the Holy Spirit may dictate and inspire if it is right for me to obtain this dignity. For I am very disillusioned about and feel neither the greatness of the possibility nor my own self estimation because I have never thought so much of myself, nor am I moved by the potential temporal benefits which are part of the promotion, but rather only the will of God, in so far as I will be able to serve Him, interests me. And through my promotion, may I spend the rest of my life, as I am 43 years old now, that is to say, whatever years might remain of my life, may I spend them all on His honor and service, His devotion, His Church, and serving the poor with the rents which this promotion may provide. Just as I have spent one of the greatest inheritances, in terms of riches and greatness, for the service of God and which I have told

\footnotetext{
${ }^{223}$ It is unclear whether Favián is apologizing for the lack of public esteem garnered by the bonnet and stones that have arrived or is actually keeping the objects hidden to avoid attention as he explains elsewhere in this letter.

${ }^{224} \mathrm{He}$ was a Milanese Cardinal from 1538 to 1584 and a counter reformation figure.

225 "For what does it profit a person if he should gain the world yet suffer the loss of his soul," is found in the New Testament at Matthew 16:26 and Mark 8:36. The Letters of Paul express similar sentiments in different words at various points.
} 
Your Reverence about already and thereby left myself poor, naked, and abandoned and without means for living. May His Divine Majesty have accepted the goodwill and joy with which I did it and through it have pardoned my sins and prepared the moment of my salvation, for it is there in the afterlife that I seek my reward for what is done. Here, on the earth I content myself with only what is necessary, so that I too may live a poor life, solitary, away from others and sustaining the obligations of my siblings ${ }^{226}$ who depend upon me for their quotidian needs.

[19] The Bishop of Michoacán, as I wrote to Your Reverence, was so elderly that when the Viceroy had named him the Archbishop of Mexico City, he promptly passed away. In this most recent fleet of ships from Spain arrived Fray Payo de Rivera who was once the bishop of Guatemala and has been appointed to the bishopric of Michoacán. There have been suggestions that he may become the Archbishop of Mexico City, and this seems certain which leaves the bishopric of Michoacán vacant and for which the bishop of Havana, Don Juan de Mañosca has arrived. Havana now remains vacant which is a reasonable bishopric, as is the one in Chiapas which is of a similar category. The same in Honduras, which is by contrast small and remote; many others will surely remain vacant in the kingdom of New Spain as they also are in Peru and in many other places which I do not remember. I am letting Your Reverence know so that you will not limit yourself to only the places mentioned in my earlier letters, but rather may the luck of the draw be what serves and benefits God, Our Lord, most for what is divinely ordained. Amen, Amen.

[20] I have very much awaited the arrival of that beautiful and perfect impression of Your Reverence's most esteemed image which was to come in the Mundo subterráneo because I plan to remove it from the book, if God grants me what I need in order to do so, so that I may send it to the noble prebends of the church in Michoacán where it will be recreated in feathers and gold, just like the Emperor's, but enlarging it as much as possible in order to be able to send it to Your Reverence as a keepsake of our in indissoluble friendship and as the best and most costly item that I can send from New Spain. What I ask Your Reverence is that when you send me the books, you do me the favor of sending all of the printed illustrations of the Obelisco which are loose in the books of the Oedipo, because with them I will make a rare curiosity which I have in mind. Likewise, do I need those from the Obelisco pamphilio. And if there were any loose printed illustrations of volcanoes and maps, the sun, moon, and earth from the Mundo subterráneo. And please do not forget about the machine with lenses which you sent me the last time as well as a telescope with four lenses like the one from last time. And two of those smaller ones, spyglasses made of buffalo horn, the finest and brightest. If there

\footnotetext{
${ }^{226}$ Favián's responsibility over his family's finances appears here as a motivator for seeking his promotion.
} 
are any other ingenious artifacts or instruments of science for this museum, it is currently short of these items that is why I would greatly appreciate them. I too will correspond with equivalently rare and precious items that I can find in this land, for I have no other concern than searching for them, asking about them and discovering new ones. Moreover, please include those glass lenses, for the intentional species which Your Reverence has forgotten.

[21] My brother, the youngest, named Don Tomás is just finishing off a poem in Castilian, to praise all of Your Reverence's works, and he humbly requests that you do him the honor of one of the Arte combinatoria, as they are published, and he will repay your gift and satisfy the debt. He is very studious, and he seems to be imitating me in nearly everything. And so, in order to assist him in finding employment and in giving himself over to studying church doctrine and the knowledge of Your Reverence, I am planning to give him all of your books which have been sent to me. And for myself, to request again all of those printed by Jansonius directly from Amsterdam as indicated in the publication list included in the Obelisco nuevo. If Your Reverence could do me the favor of letting me know how much the complete set of your works would cost directly from your printer, all bound there, without leaving any out and including the latest publications, in the beauty and style used by that printing house, except those which the Index ${ }^{227}$ puts a cross beside as a signal that the works are no longer found. In this way I will be able to ascertain the total cost and send the silver and other materials, requesting that Your Reverence could arrange it for me as if they were for yourself at the lowest possible price, because of the poverty that I find myself in these days. And if I had the abundance of the past, I would not need to concern myself with the cost.

[22] It will be necessary that Your Reverence let me know about this as soon as possible or on this fleet, not including the books which should be brought from Amsterdam. So that you might do me the favor of sending those that are missing now in order to complete the full corpus with those that are already here and which I need to give to my brother, regardless of whether they were printed in Rome or by Jansonius, namely the China illustrata, and the San Eustachio, and those which have just been published. Also, with those of the Magia I would esteem it greatly if Your Reverence would do me the grace of sending the Iter extaticum celeste which Father Schott has illustrated with new commentaries, in Nuremberg, because for my work it will also be very important and especially if it has engravings and images of the planets as Your

\footnotetext{
${ }^{227}$ Book titles which the Roman Inquisition had listed on the Index usually had particular lines of text specified for excision, and printers were forbidden from reprinting them. In Mexico City, book owners who already had the books at home were instructed, by posters put up by the Mexican Inquisition, to draw a line through the offending parts of the text. In Rome, Kircher's works were scrutinized by officials within the Jesuit order, and he famously had his books printed regardless of their recommendations (Stolzenberg 2013, 180f).
} 
Reverence added in the Mundo subterráneo illustrations of the moon and the sun. I would be very appreciative of it because I would like to include them in my volume of the Tautología, where I will describe the celestial spheres in order to demonstrate more clearly for the eyes, those new phenomena and wonders which will be very important for all the realms where Castilian is spoken.

[23] I am not writing to the Señor Cardinal, my patron; to Our Father General, to the Señor Count and the others because, since I have not received your letters, I would not be responding to them with the appropriate words.

[24] I am stopping here in order to not tire Your Reverence anymore, but I will not cease praying to Our Lord and his most holy mother to keep you many long years in good health and strength for the good of the world, and for my own sake.

Today 14 November 1667.

Your humble and affectionate son who loves you truly,

Don Alexandro Favián.

APUG. Vol. 559 EPISTOLARIO KIRCHER

V, Fols. 27r-42r.

\section{Letter 11}

To Father Athanasius Kircher,

Most Reverend Father, the most Beloved and Esteemed of my Friends:

[1] In April of last year, 1671, I wrote a lengthy letter to Your Reverence and to all those señores who are my dear friends. In the letter I gave my account of everything that has taken place here, and specifically, how much has happened to me and the state in which I and my finances were in and still are in presently. I believe that all ten of these letters must have arrived there in Rome, since I was sure to find only trustworthy hands for their delivery, namely a gentleman from Spain, named Don Fernando de Yepes y Noé, who is a vecino of the Port of Santa María, ${ }^{228}$ and to whom I gave the letters as well as a power of attorney before the royal and public notaries of the Puebla city council so that in the court of Madrid my person can be legally represented so that if His Majesty, God preserve him, were served by deciding to grant me the grace that the gentleman will request for me, the dispatches, licenses, and royal mandates, which in this case would be necessary at the court in Madrid and at the Council of Indies ${ }^{22}$ just as it would be necessary for Your Reverence in Rome when requesting the papal bulls. All of these things were discussed and negotiated with the gentleman, and he willingly offered to do it

\footnotetext{
${ }^{228}$ The vecino was a property owner and, presumably, a distinguished resident of that city; in this case he is a resident of the town next to the port of Cadiz in Spain. At this time a change in official Spanish ports was taking place and, by the 1670s, the shipping delays caused by large sand banks in the Guadalquivir River of Seville had made Cadiz the preferred port for ships crossing the Atlantic. ${ }^{229}$ The king of Spain's council on affairs to do with the colonies.
} 
because of the maestrescuelas ${ }^{230}$ of this cathedral of Puebla who is presently blind and living here at this sugar mill which belongs my cousin and brother-in-law don Francisco Colón. ${ }^{231}$ The said maestrescuelas who arranged the matters of legal representation in Spain did so in the manner that he had used in the past for achieving posts and recognitions that have come from Spain. Indeed, if he had not been impeded by losing his sight, he would already have become a bishop, despite being such a young-looking sixty years, for he has been proposed for the bishoprics of Havana, Oaxaca, and the Isle of Santo Domingo.

[2] And so I am still absent from Puebla, retired and hidden in the emptiness and deserts of this sugar mill, which belongs to my brother-in-law, after having sent all of the letters with general notices of everything by way of this gentleman Don Fernando de Yepes in May of 1671. I have been confused and perplexed because so much time has passed since I received any notice from Your Reverence. It has been a great source of unhappiness and grief because I have not known the cause, even though I have always been careful to send my letters via reliable couriers and yet my letters appear to not have reached your hands. I supposed that if Your Reverence did not approve of what I had written or did not want to correspond with me anymore in the way that we had so many times earlier with statements of appreciation and true kindness and so many demonstrations of loyalty and friendship, perhaps you wanted to stop the correspondence. Or perhaps it was because I could no longer continue sending gifts since I ran out of worldly possessions and property due to the expenditures and disputes which consumed them. Could it be because of one of those persons, ${ }^{232}$ who so greatly dislikes me and has persecuted me without so much as a reason, has written negative words about me to Your Reverence? But neither one nor the other of these two possibilities seems plausible to me; because I do not believe that simply because I am no longer endowed with the financial resources that I once had that your noble spirit would permit you to exclude me from your communications, friendship, and goodwill which go back so many years. Nor do I believe that you would reject my communications if someone had written unkind words about me because your good judgment would have shown you that anyone who could write such things was not being moved by love for God but, instead, by envy and a desire for superiority which they have had since they found out that Your Reverence had sought to honor me, through your great friendship, with a post of such great dignity which has been attempted by way of the Emperor, God protect him, I say curam Deo et Jesuchristo. ${ }^{233}$ This does not worry me because I know and am well

\footnotetext{
${ }^{230}$ The maestrescuelas was a professor of ecclesiastical studies at a cathedral.

${ }^{231}$ Favián does not name his three sisters, but two are nuns at the convent of Santa Inés and the third is married to a "primo" Francisco Colón.

${ }^{232}$ This seems to be a reference to Ximénez.

233 "God and Christ protect him."
} 
convinced of Your Reverence's goodwill; I know that you have done your best on my behalf and I believe as an article of faith that if Our Lord God would like me to serve him somehow in this role of dignity or in any other, there are not enough demons or angelic powers, nor are there men strong enough to impede or change whatever God wants to have happen. If my becoming a bishop will not serve God, then it could be impeded by something as minor as a strand of hair.

[3] And so, as I am not seeking anything other than providence, nor am I motivated by honors, splendor, or at all by riches; these do not worry me because as I have stated already with the utmost candidness and sincerity in previous letters to Your Reverence: I do not insist on the bishopric because I think so highly of myself or my abilities, nor for the dignity and honor or even the comfort and riches, but rather that these are conjoined with it simply for the glory of God and his church as well as the souls in need, of which there are many in these kingdoms as they are joined to the salvation of my soul as well, by using all its associated temporal goods for the sake of spiritual goods by living and working in a saintly manner as did
Saint Carlos Borromeo, ${ }^{234}$ Thomás de Villanueva, ${ }^{235}$ or Saint Francis of Sales. ${ }^{236}$ And if it would not be for the spiritual good of all involved then I do not want it, I do not want it, I do not want it, I do not want it, and I would not say such a thing but that it should not bring Your Reverence the slightest comfort in helping me unless I become the poorest, most forgotten, broken, despised priest in the world until I become opprobrium omnium et abiectio plebis, ${ }^{237}$ and spend my life begging from door to door and to retire to one of my ermitas ${ }^{238}$ or churches of my congregation where I will spend my years poor and retired in the company of my fellow ordained brothers, the other priests who live and work there, until the end. For, in my assessment, there is no greater glory, honor or wealth in this life than those holy retreats, those solitary cells ${ }^{239}$ and sanctuaries where the stations of the Cross are venerated and so many souls are being cared for in this life and in the other. $^{240}$

[4] Returning now to what I was saying earlier that I could not imagine why Your Reverence had not written to me, and I wondered if you had passed on from this life to eternity, but I was not convinced of this because my

\footnotetext{
${ }^{234}$ As mentioned before, Borromeo was canonized in 1610 . He was from a wealthy family and gave part of his wealth to the poor.

${ }^{235}$ Villanueva was canonized in 1658 and had famously given his inheritance to the poor.

${ }^{236}$ Francis de Sales was canonized in 1665 and had renounced his noble titles; the year of canonization is significant because of how recent the event would have been. Favián is clearly suggesting that he will use any wealth which he might gain to benefit those in need, and he is also reminding Kircher that he has already spent a great deal of his inheritance, perhaps even sold his family home, his hacienda, to pay for the renovation of chapels in Puebla.

${ }^{237}$ A person shamed and rejected by others in the way that Christ was.

${ }^{238}$ A retreat space attached to the chapels which he renovated.

${ }^{239}$ Cells are the simple, individual bedrooms within a convent or monastery.

${ }^{240}$ A reference to the belief that souls in Purgatory can be sent to Heaven by prayers from the living.
} 
correspondent Francisco María had written to me from Genoa on varied occasions that Your Reverence was very well and occupied with the usual tasks of writing and printing books and so that is why, with a heavy heart and much worry, I have tried to imagine how it was that my letters from the last two years might not have arrived in Rome and how Your Reverence could have forgotten to write to me, when at this moment I have been writing to our friend the reverend Father Francisco Ximénez in Mexico City regarding certain complaints he had about me for reasons related to my not having had a chance to send him certain books, which Your Reverence had sent to me for him, because I was no longer in the city of Puebla. By the grace of God, I received a letter from Your Reverence written in your hand in Rome and dated 31 December 1670 , by way of Mexico City whence it came to Puebla in the hands of Roque de Molina, a Jesuit priest. I received it on the twelfth day of March, Pope Saint Gregory's feast day of this year 1672. Your letter was such a great source of joy for me that I cannot think of what to compare it to. Firstly, because it was evidence that Your Reverence was alive and well; secondly, for all of the news which your letter contains, principally regarding His Majesty the Emperor's having written to his sister the Queen of Spain ut vaccante episcopatu, di Mechiocan omnibus aliis me praeponeret, idque maximis instantiis ${ }^{241}$ and how there Your Reverence tells me immediately if this imperial favor which the emperor does for me has been achieved or not.

[5] To which I say that I have already responded at length all that has taken place here and how it has been a long while since the bishop of Michoacán, an Augustinian priest named Don Francisco Sarmiento, the brother of the Count of Salvatierra, who was the viceroy of New Spain some years ago, arrived. And since everyone in that province as well as the canons of that church and all in this kingdom have been convinced that I would be the one to arrive as their bishop rather than the person whom they were assigned, about which we have all been disappointed. Then it became known that the said bishop of Michoacán is attempting to return to Spain because that is how his brothers want it and, on the ship, currently at port which arrived recently it is said that there is an order from our Queen for him to return to Spain; and that she is set to grant him the archbishopric of Coria in the Kingdom of Galicia where he and his people are from. I and indeed others who know that I have been attempting to secure the post, have thought that perhaps the Queen is calling him so that the bishopric of Michoacán would be vacant in order to name me for it since His Majesty the Emperor, her brother, requested it in his first recommendation that he made of my person for this bishopric and which she, in order to fulfill such a great and royal petition and request, she would like to move

241 "Regarding the vacant post of the Michoacán bishopric, that I should be preferred to all others and that is best." 
him to another more appropriate location in order to place me in this bishopric.

[6] This is my current thinking about this and that of others who are concerned as well, but as of now, 20 April of this year, 1672, in which I write, we have not known nor had real evidence of this royal directive. That he was called back is not doubted but that I have been named remains uncertain. And so, I request of Your Reverence by way of this notice about what is taking place, that you may urge His Imperial Majesty to write to his sister, to move the said bishop to a larger and better bishopric from among those in Spain or from here, and that she may name me a bishop and in this way to the church of Michoacán. Waiting for the bishopric to become available because of the said man's passing or even attempting to wait for its becoming available with the passage of time once the current bishop is moved to a post elsewhere would all be such a slow matter that one's life could be spent on waiting with nothing but hope to show for it, and then when it did come to fruition I would be so elderly, worn out, and unwell that I would not then be able to accept the post. And if I were to accept it, the associated concerns and obligations of its apostolic ministry might be too much for me. But if our Queen does not want to or is not able to move him, then you can ask our Imperial Majesty to name me to any other in New Spain even if it is small, poor, and has few people so that I will not waste away but rather be occupied with a holy ministry such as this in the interim, while it becomes more convenient for the bishopric of Michoacán, or a large and populous one in New Spain, or the kingdom of Peru, for which I could be considered, becomes available; for the seeds and the sowing being great will give me much to work in to satisfy my desire to labor for the service of God in His apostolic ministry and its furtherance with efficacy, courage, and perseverance.

[7] For all this I await the response, however brief it might be, from Your Reverence in order to know in what way it would be best to approach this matter, while I am in the meantime retired as I indicated in my previous letters, and which must also have been the reason that no one, not even the Father Procurator, named, Florencia I think, who left for Rome from these kingdoms has mentioned me, because, honestly I have not assisted at mass in the city these last, nearly four years because I have not been able to sustain myself there with my siblings due to the exceptional poverty that I have arrived at as I explained to Your Reverence in an earlier letter. And also, about the many expenditures, sorrows, disputes, and persecutions that have arisen without my having given the slightest provocation for it, at all, to anyone, because as it is clear to this entire city, I am a priest who is so calm, retiring, and peaceful; since childhood, I do not remember nor can I imagine, having caused anyone concern or displeasure. And with everything that has occurred and those who have decided to oppose me without admitting that it is due to an unrelated matter, namely the idea that through Your Reverence's influence I might be granted a bishopric as if through this I were going to take their posts away or any of their 
riches that they enjoy at the cost of so many people who lack them. This line of thinking is a mere attempt to outdo me and envy that I might exceed their dignities through Your Reverence's hand when I am an unworthy person who is in no way equal to not only this great dignity but also the most minor post that there might be in all these kingdoms, regarding which I know it is said that I aspire to. But if it is the will of God that this "dull and ignorant" man, a "useless" priest in no way adequate, should serve Him in this fortunate state which he clearly does not deserve, what fault does he have, if he has not sought it or desired it for his own benefit, nor does he pretend to deserve it, if God wills it without removing anything from anyone else, and instead gives freely to everyone what they need according to their dignity.

[8] I was gladdened by the great warmth and fineness of friendship with which Your Reverence's letter started, where you, as a true friend have inquired about me, about how things are progressing, and finally about whether I have passed away due to the absence of my letters since my letters had become lost. And also, because I have been absent and hidden from Puebla in retreat to the countryside. This all while I too experienced the same feelings, wondering how you were in Rome and asking about you of anyone who might know, why I had not received letters from you in such a long time and whether you were alive or dead. Among those who had come from there was a discalced Franciscan who said that he had just come from Rome, Father Nicolás de Pantoja and the unordained, Friar Juan, so that they could give me news about Your Reverence. Likewise, I also travelled more than 10 leguas $^{242}$ to find a discalced Franciscan priest who was said to have arrived from Rome to ask about Your Reverence, but I did not find him because he had already left for the port of Acapulco whence, he departed for Japan. Before him, I had also looked for another priest, one belonging to the order of San Camilo, who had arrived here from Rome named Andrea Chiguilia. He collected donations in a small trunk decorated with metal clasps that he would take to Masses when offering indulgences which he carried with him. But I found them bewildered by my inquiries; they could not allay my concerns even upon reading Your Reverence's letter and admiring the way that our alternating correspondence shows that our natures are ruled by a mutual and reciprocal sympathy and care. We have been inquiring about one another despite being faraway; by such loyal and genuine sentiments, I recognize the truth and clarity of what Your Reverence tells me in your letter, and also that love is full of attentive apprehensions about that which is esteemed and loved: res est solliciti plena timoris amor, ${ }^{243}$ as I too experienced the same feelings at not hearing from Your Reverence in

\footnotetext{
${ }^{242}$ There are approximately four kilometers per legua making ten of them a full day's walk, but then "diez leguas" could also be a figure of speech for the average distance between cities.

243 "Love is a thing of anxious fears," is a quote from Ovid's Heroides. Favián clearly enjoys including well-known quotes in Latin; he was educated by Jesuits and was taught classical humanistic
} 
Rome that you felt about not knowing how I have been and the state of my affairs.

[9] I am greatly pleased by the notice you give of the books which have recently been born of your inexhaustible talent and I appreciate the promise that you will send them as soon as you are able, since, as you already know, I have no greater pleasure and entertainment from work than these works from Your Reverence because they are so well-matched to my way of thinking. When I read them, I see myself portrayed in what is being said, as if it were not Your Reverence writing it but myself; that is how closely our natures and wits align for which reason I ask humbly that you not forget to send the following books along with your letter: Latium sive de antiquitatibus territorii rom alli; Arca Noe, Turris Babel, Archetipum politicum et horaris descriptio, and also the Arte magna de la luz y sombra which have been reprinted cum insigni novarum inventionum augmento $^{244}$ which I would appreciate greatly because I have my current work, about the composition of light, that I am planning at ten cuarto $^{245}$ volumes and which I am, at the moment, writing in the Castilian language, which is the most convenient for this land since
Latin is neither practiced nor used here. Again, your work on this topic, in its best quality imprint, is most important and would help me tremendously as well as the additional materials. Having this will allow me to give the other copy to my brother Don Tomás who is both an ingenious and studious student of your works and a great Castilian poet who has written many verses, in honor and praise of your works and my own, which will all be printed with my works.

[10] I hope that Your Reverence will be willing to send the work on China and the one about San Eusthacio, because those two were removed from the box in the port of Cádiz where it was opened, which I noticed then and again now I realize based on what Your Reverence has written legeri placet opusculum cui titulus historia Eusthacio, mariana, iam dudum a me aeditum et a te transmissum ${ }^{246}$ regarding the San Eustachio which I have neither seen nor received; there are also others missing including those that were coming for Father Alvarado, namely the Arithmologia and the new Obelisco, in addition to a few of mine which were going to be bound, in fact none of the ones that should have been bound arrived,

works. Greek authors used a variety of terms for love which, in combination with the Biblical and theological conceptions that Favián was conversant in, suggests that he may be thinking along the lines of storge (familial love and duty), philia (feelings of affection between friends), and agape (feeling pain when others suffer).

244 "With the notable addition of new inventions included," reads like a quote from promotional or advertising materials, perhaps from one of Kircher's letters or from the list of publications which Kircher's publishers include on a sheet inside his works.

${ }^{245}$ A medium sized book.

246 "Please read the History of Eustachius which I have published and send to you." Saint Eustace was an early Christian martyr, and his example may have been intended as a reminder to Favián to take courage. 
which I understand now, and I remember that many other items seemed to be missing since they must have been unpacked and opened the full contents. Much of what has been removed must be what they found most pleasing. This I recognize now was the reason why they did not want to deliver the letters that Your Reverence had sent along with the crate since the letters would have made clear what was missing. We were not able to convince ourselves that such a naked, un-nailed box could have been sent all the way from Rome without letters especially since the contents included gifts from so many different señores and nobles.

[11] Last year I sent a list of book titles to Francisco María in Genoa so that he could request them from Your Reverence on my behalf with an order to send you whatever you asked for in terms of payment for them, or for him to contact the gentleman in Spain who took my letters last year to cover the costs involved. The book titles follow.

[12] The four tomes of La magia natural by Father Gaspar Schott to whom Your Reverence gave the works in order for him to publish in his own name and which you sent me some years ago. These I have very much wanted for the mechanical diversions they contain and with which I typically enjoy busying myself.

[13] The Curso mathematico by the aforementioned author Schott in whatever

number of tomes as it might come, the Iter extaticum caeleste, supplemented and illustrated with its various commentaries by the same Father Gaspar Schott, which is supremely important for my other work, my Tautología which I have divided into five folio volumes, and which I have stopped writing until I consult his book.

[14] Another book on this same topic was promised by Señor Juan Caramuel in his writings. He was to have published with fine images made from copper plate etchings, celestial globes, planets and other stars with such rare forms, figures and shapes that have been newly found with the latest astronomical telescopes, along with other most singular phenomena which he says he has found on the face of moon and the planets, all of which he says that he will make visible drawn in those prints of each celestial globe. I have received notice that the book had been released and that it had been taken all over these regions; and so I humbly ask Your Reverence to obtain a copy for me so that I may use it for volume three of my Tautología, because I already have the globes of the planets drawn in the manner that Señor Caramuel describes and we can see whether it agrees with mine or not; so that I can judge whether mine are good. And so, I hope that it may arrive soon, since in mine and that of Father Schott, which is the same, I have many to illustrate this matter and its book well. ${ }^{247}$

${ }^{247}$ Favián seems to be basing his own illustration designs upon those appearing in related works. Elsewhere in his letters he does mention that his images are variations on those of others which he seems to be hinting at here again. 
[15] Additionally one or two authors who handle with clarity and facility the sciences of lenses, refraction, and mirrors would be ideal for my work on the nature of light, in which work I have a unique approach and am going down an altogether different track.

[16] Also by Señor Caramuel, if they might be available in Rome, the following: Steganographia sublimiorum ingeniorum crux, ${ }^{248}$ and for the attention to detail that the author has given it and for whatever it might contain, Solis et artis adulteria [1644], Musaeum mortis [1637], and another work about music. These are the titles which I had listed plus the addition now of the one about the celestial globes by Señor Caramuel. All of these along with the ones which you listed in your letter and the Arte combinatoria, which is greatly sought out here for which reason I pray that it will not be forgotten. If it pleases Your Reverence to send me the works all together in a crate that is locked and sealed so that no one will open it like they did to the other one, and may the works all be bound there because as I have suggested at other times, if they arrive unbound there is little hope for them here since there is no one here who has the talent to bind them in the manner that they deserve.

[17] I have longed very much to know whether there is an author out there who has written about the art of repairing and assembling clocks with gears because although I have made very precise inquiries about it, here in these realms it has not been possible to find out, I have received neither word nor notice of it. And so, I request in addition that Your Reverence may forgive me for all the work and bother that I give you with my impertinent petitions; if there is a book there concerning this matter that you would please send it along with the others, in any language, although Latin, Tuscan, and Spanish would be best if they are available. In my spare moments of rest from studies and other occupations, I occupy myself with clockmaking for my diversion and exercise. And for such an art as excellent and difficult as this one, since there are not in these realms teachers who understand or teach it, it is more difficult than necessary for me in doing it. Only if this information is not contained in one of the books of La magia natural which Your Reverence gave to Father Schott for him to publish in his name. In Your Reverence's Arte de la luz y de la sombra, volume $\mathrm{X}$ and also in the first part of La Magia horographica, problema XXV, folio 798 and also in the Misurgia temor pragmatica $\mathrm{V}$ folio 311, where it says that in the Statica universalis all types of geared clocks are discussed and the same is promised in the Pragmatica VII folio 330 where it says that El arte magno de lo grave y de lo leve, in the chapter on Mechanica statica, the theme would be treated, which is why I believe, as I said before, that in the volumes of the Magia natural the art of geared clocks will be thoroughly expounded upon.

${ }^{248}$ A book on ciphers and coded messages from 1635 . 
[18] Insofar as Your Reverence tells me the location of the true San Eustachio that you have found, and the church that was rebuilt and rededicated in honor of the most holy Virgin and the saint, for that magnificent building all the nobles and their friends and the cardinals have contributed and helped, among whom although I am unworthy, you ask for a contribution to such a holy task and moreover as it is for the glory of Our Lady, the most Holy Virgin for whom I am sending a piece of silver so that she may bless me tenfold.

[19] To which I respond not with my quill and ink, but rather with tears of blood from the depth of my heart, which has been pierced through until making it flow from my eyes with the pain which my soul feels from my current state and how I presently find myself, so insolvent, poor and without recourse. I have not even had enough to be able to send Your Reverence a little chocolate, and so I am feeling financially broken now. I have felt anguish and it wracks my heart, my soul. And when I reflect upon the liberality with which God has blessed me and how I not only do not feel tied to money or gold or silver but rather have a natural propensity and inclination to give and spend what I have, and more for things, which are of greater wealth, as for example I had inherited so much wealth from my parents and I invested it in the construction of churches and in the promotion of divine worship and the service of God without anyone in this land ever seeing or hearing of me spend anything on sport, finery or other profane expenditures, not even a single real. It rests with Your Reverence if I will find myself with many goods and riches, and as for whether I will send help for your church, and by help I do not mean simply help but rather that the entire project will be completed with my contributions; to the truth of this I ask for God's testimony in whose presence I write and also that of the most holy mother, to whom the church is dedicated and whom I venerate and honor, and who now as I write this has held back the tears and pain that I feel in my heart over seeing myself in this unfortunate state. It is with only this will from God and Your Reverence that I find myself, but without strength or temporal goods with which to carry them out and to double amount since everyone $^{249}$ in my patria has an hacienda, is wealthy and at leisure without needing to spend a cent on anything. And I who have spent on blessed things find myself poor and without a single comfort with which to spend on the rest of my life traveling from one place to another, pursued by tribulations and persons whom I have never offended. Finding myself in this state with only goodwill left to use in the service of God, with my soul and my life, anything that I might have without seeking by way of it any reward or honor, nor any other glory than the

\footnotetext{
${ }^{249}$ Favián here identifies a class of enfranchised people that he is comparing himself to: estate owning men who are called upon to lend the city council funds, when necessary, like his father did. It is worth noting that he does not appear to be comparing his financial means to that of an average clergyman of his place and time. Despite his vocational commitments, Favián identifies with the lifestyle of the wealthy criollo class into which he was born.
} 
desire to see God, His mother, and His saints valued with the requisite honor and one of the reasons why I would like to have many rents and riches is so that, as I've written before, I can spend it on this.

[20] Your Reverence should not doubt even a little about whether I would send the silver for your building project that you ask for in your letter had Divine Providence already wanted me to become bishop of Michoacán; indeed, I would send enough for the shining completion of your church building because Michoacán is a place of many mines. And I would not only contribute a hefty portion of silver and gold, but I would also solicit much more by asking all of the canons and prebends of my church to each help me and Your Reverence with such a praiseworthy objective; each of them would give me a sizeable amount. I would also ask the magnates and wealthy men of the city and of the parish as a whole, so that between myself, the council and the cathedral, the wealthy, the nobles and all the other residents of the city as well as the entire region and jurisdiction, which is very expansive, where I would ask for donations from everyone while visiting all of the bishopric. ${ }^{250}$ This is why I believe that Your Reverence would be able to build two or three churches in Rome with the money that I would contribute, as I would do as I have indicated to gather the funds, and I call again on God to witness the truth and purity with which I speak. I would do it with my spirit, with my heart, my blood and would open my veins if doing so would bring more donations. This is my inclination, my desire to spend in this manner everything that God might give me. I also intend, if Our Lord God were served by my becoming a bishop, to next construct His church and cathedral in Michoacán because the current one is very old and restrained in style. And I would establish a new convent and church dedicated to Saint Inés of Montepulciano where the relic, which Your Reverence sent years ago, will be housed. Therefore, I have not wanted to give it to the nuns of her convent in Puebla, nor to the Dominican convent although they have both asked for it, until finding out what the emperor thinks of my request so that I can one day install, with my own hands, the relics of Saint Inés in a new church in Michoacán. This would be a great service to God in that province and a great good to all of her devotees, because in this way she would have a place for her spiritual daughters to enter this new convent, as there is only one at the moment and it is very poor and lacking in resources, for which order Your Reverence might like to inquire for me about the regulations and constitution that the nuns of Montepulciano preserve and adhere to, along with the style of habit which they wear and which I presume is more rigorous and observant. That is what I am aiming for because

\footnotetext{
${ }^{250}$ This is one of Favián's descriptive imaginings about his future self. His persistent fantasizing may have worked against him by irritating Kircher's mutual friend, Ximénez, who had the power in Mexico City to block any of Favián's promotion requests. Nevertheless, it is worth noting that Favián sees the structure of the church hierarchy as potentially having opportunities for persons of his class and background.
} 
the ones that are here in Puebla follow the rule of Saint Dominic and they are not very disciplined about their regulations, or they are vain, although they are all very holy and good, for which reason it would be helpful to have a portrait of the saint from Italy dressed in the habit that the nuns of her convent dress in. Additionally, I hope to establish, if God sends me to Michoacán, my Congregation of the Santa Compañía de Christo, with its thirteen churches or ermitas, as they are known here, like I did here in Puebla because it is my goal, and I hope to end my days in them. And it is this holy institution that I most long for and where my heart and sentiments reside.

[21] And so, Your Reverence, please wait and be patient to see if we can reach by way of the emperor my appointment in Michoacán or some other large and prosperous bishopric. In this way, there will be no need to tire you with soliciting from officials in Rome, but only to await my remittance at the earliest year possible for you to build your church and to make it very tall and in the years that follow as well. Moreover, it is possible that in the first year's remittance that I may be able to send enough silver for the entire church to be built all at once. And so, it would not be a bad way to prepare, if Your Reverence were to send me an estimate of the total cost of the church construction including all that Your Reverence hopes to add to it, so that I will know and as soon as I arrive in Michoacán, I will be able to solicit the funds right away, which I have said and could say a thousand times over that I will do with my soul and my life if God is served by granting me the estate, the power and the dignity necessary for it, according to His most holy will, and directs everything I am working towards.

[22] I won't say anymore except that time will be a witness to all that I have said. And I end by asking God to protect Your Reverence with a long life and continued good health, to comfort, protect and honor me as your true and fine friend.

Puebla de los Ángeles and New Spain, the $20^{\text {th }}$ day of April, feast of Santa Inés de Montepulciano, 1672.

Son of Your most Reverend Father, who loves and esteems you above all other friends,

Don Alexandro Favián, Unworthy presbyter. ${ }^{251}$

[23] In last year's letters I petitioned Your Reverence repeatedly to do me the mercy of sending a spyglass for long distance viewing, the type with four medium-sized lenses like the one which you had sent some years ago which extended and expanded one's sight significantly. And also, one of the small ones made of buffalo ${ }^{252}$ that is clear and of a good quality for which I will pay twice its value, as well as other lenses principally a large one. I ask humbly that they arrive with the books.

\footnotetext{
${ }^{251}$ What follows is a one-paragraph postscript.

${ }^{252}$ Possibly the telescope shaft, rim or decorative handle was made from a buffalo's horn; Mediterranean water buffalo would have been a ready source of this material.
} 
APUG. Vol. 565 EPISTOLARIO KIRCHER

XI, Fols. 146r-152v.

[End of Alexandro Favián's Letters to Athanasius Kircher] 


\section{Concluding Notes}

The annotated translation presented here is aligned with what is known as "cultural translation" in that it presents another culture, and indeed introduces another epoch, "via translation" (Sturge, 2008 p.67), and also renders a set of historical texts accessible to the contemporary reader. Overall, my project makes three significant contributions. First, it examines how fluid positionality within a metropoleperiphery dynamic was leveraged by colonial writers to negotiate the exchange of scientific ideas and objects with other figures more centrally situated. Second, it offers a case study of reader reception for Kircher's prolific output. Finally, it makes a seventeenth-century colonial author's words available in English with a scholarly apparatus for the first time. My goals when translating were to make the text accessible to a contemporary audience of students and scholars who may not be familiar with New Spain or the history of Mexico, and to be accurate in the rendering of historical terms. I hope that the historical detail is drawn out in useful ways and that the reader finds the annotations helpful as case studies for a variety of entries into the history of colonial Mexico.

The scholarship on Alexandro Favián is still in its infancy but may soon develop as scholars begin to publish their findings about him, namely the Puebla-based scholars, Maestro Gustavo Mauleón Rodríguez, and Maestro Fabián Valdivia Pérez. My overall aim is that this set of annotated translations contribute to critical studies in the area of colonial early modern science and promote interest in the Puebla historic archives. 


\section{Bibliography}

Achim, Miruna. 2001. Fractured Visions: Theaters of Science in Seventeenth-century México. New Haven: Yale University Press.

—. 2011. Itinerarios e intercambios en la historia intelectual de México. México: Dirección de Publicaciones del Consejo Nacional para la Cultura y las Artes.

Andreu, Juan Pablo Salazar. 2019. "Semblanza del único obispo angelopolitano de origen criollo en el periodo de los Austria: Alonso de la Mota y Escobar." Hipogrifo: Revista de literatura y cultura del Siglo de Oro 7.2: 863-871.

Aram, Bethany, and Bartolomé Yun-Casalilla, eds. 2014. Global Goods and the Spanish Empire, 1492-1824: Circulation, Resistance and Diversity. Basingstoke: Palgrave.

Arias, Arturo. 2003. "Politics and society." The Companion to Latin American Studies, ed Philip Swanson. London: Routledge.

Arinero, María de los Ángeles Calatayud. 1988. Pedro Franco Dávila: Primer director del Real Gabinete de Historia Natural fundado por Carlos III. Editorial CSIC-CSIC Press.

Baker, Mona. 2018. In Other Words: A Coursebook on Translation. London: Taylor \& Francis.

—. 2004. "A corpus-based view of similarity and difference in translation." International journal of corpus linguistics 9.2: 167-193.

Bass, Marisa Anne, et al. 2021. Conchophilia: Shells, Art, and Curiosity in Early Modern Europe. Princeton: Princeton University Press.

Bleichmar, Daniela. 2021. "The Cabinet and the World: Non-European Objects in Early Modern European Collections." Journal of the History of Collections 33.3: 435-445.

—. 2009. Science in the Spanish and Portuguese Empires, 1500-1800. Stanford: Stanford University Press.

—. and Peter C. Mancall, eds. 2011. Collecting across Cultures: Material Exchanges in the Early Modern Atlantic World. Philadelphia: University of Pennsylvania Press.

Bonialian, Mariano Ardash. 2012. El pacífico hispanoamericano: Política y comercio asiático en el imperio español (1680-1784). México: Colegio de México.

Canepa, Teresa. 2016. Silk, Porcelain and Lacquer: China and Japan and Their Trade with Western Europe and the New World, 1500-1644. London: Paul Holberton.

Cañizares-Esguerra, Jorge. 2006. Nature, Empire, And Nation: Explorations of the History of Science in the Iberian World. Stanford: Stanford University Press.

—. and Masters, Adrian. 2022. The Radical Spanish Empire: Petitions and the Creation of the New World. Cambridge, Mass.: Harvard University Press.

Castanien, Donald. 1954. “The Mexican Inquisition Censors a Private Library, 1655.” Hispanic American Historical Review 34.3: 374-392.

Chen-Morris, Raz, and Gal, Ofer. 2014. Baroque Science. Chicago: University of Chicago Press. 
Cruz, Anna. 1992. "Self-Fashioning in Spain: Garcilaso De La Vega.” Romantic Review 83.4: 517538.

Davids, C. A. 2011. "Dutch and Spanish global networks of knowledge in the early modern period: structures, connections, changes." Centers and Cycles of Accumulation in and around the Netherlands during the Early Modern Period. Berlin: LIT Verlag, 29-52.

Dietz, Bettina. 2016. "Introduction: Special Issue 'Translating and translations in the history of science"”. Annals of Science 73.2: 117-121.

Egan, Martha. 2020. Relicarios: The Forgotten Jewels of Latin America. SF Design: LLC, 2020.

Eamon, William. 2017. "The Scientific Education of a Renaissance Prince: Archduke Rudolf at the Spanish Court." Alchemy and Rudolf II: Searching for the Secrets of Nature in Central Europe in the 16th and 17th Centuries. Eds. Purš, Ivo and Vladimír Karpenko. Prague: Artefactum, 129-38.

Efford, Alison. 2019. "What Historians Can Learn from Translators." The American Historian, Organization of American Historians. https://www.oah.org/tah/issues/2019/history-and-themovies/what-historians-can-learn-from-translators/ Last accessed 7 August 2021.

Feest, Christian. 1990. "Vienna's Mexican Treasures: Aztec, Mixtec, and Tarascan Works from 16th Century Austrian Collections." Archiv für Völkerkunde 44: 1- 65.

Feingold, Mordechai. 2003. Jesuit Science and the Republic of Letters. Cambridge, Mass.: MIT Press. Findlen, Paula. 1995. Scientific Spectacle in Baroque Rome: Athanasius Kircher and the Roman College Museum. Rome: Università degli Studi Roma Tre.

— . 2004. "A Jesuit's Books in the New World." Athanasius Kircher: The Last Man who Knew Everything. New York: Routledge, 329-364.

— . 2001. "Science, History, and Erudition: Athanasius Kircher's Museum at the Collegio Romano." In The Great Art of Knowing: The Baroque Encyclopedia of Athanasius Kircher ed. Daniel Stolzenberg, Stanford: Stanford University Libraries, 1000-1010.

— . et al. A Jesuit's Letters: Athanasius Kircher at the Edges of His World. Online resource. http://emlo-portal.bodleian.ox.ac.uk/collections/?catalogue=athanasius-kircher

Last accessed 10 January 2021.

Fletcher, John. 1969. "A brief survey of the unpublished correspondence of Athanasius Kircher, SJ (1602-1680)." Manuscripta 13.3: 150-160.

— . 1988. "Athanasius Kircher and his correspondence," in J. Fletcher, ed., Athanasius Kircher und seine Beziehungen. Leiden: Brill, 139-95.

— . 2011. A Study of the Life and Works of Athanasius Kircher, 'Germanus Incredibilis': With a Selection of His Unpublished Correspondence and an Annotated Translation of His Autobiography. Leiden: Brill.

Flynn, Dennis O., and Arturo Giráldez. 1996. "Silk for silver: Manila-Macao trade in the 17th century." Philippine Studies 44.1: 52-68. 
Frankenberg-García, Ana. 2004. "Are translations longer than source texts? A corpus-based study of explicitation.” In Third International Corpus Use and Learning to Translate Conference (Barcelona 22-24 January 2004) Reprinted in CIC-ISLA Working Papers Lisboa: ISLA 1.

Gasch-Tomás, José. 2014. "Globalization, Market Formation and Commoditization in the Spanish Empire: Consumer Demand for Asian Goods in Mexico City and Seville, C. 1571-1630.” Journal of Iberian and Latin American Economic History 32.2: 189-221.

Godwin, Jocelyn. 1979. Athanasius Kircher: A Renaissance Man and the Quest for Lost Knowledge. London: Thames \& Hudson.

Gorman, Michael. 2020. The Scientific Counter-Revolution: The Jesuits and the Invention of Modern Science. New York: Bloomsbury.

Grafton, Anthony. 2009. "A Sketch Map of a Lost Continent: The Republic of Letters." Republics of Letters: A Journal for the Study of Knowledge, Politics, and the Arts 1.1: 1-18.

Granovetter, Mark. 1973. “The Strength of Weak Ties.” American Journal of Sociology 78.6: 13601380.

Greenblatt, Stephen. 1980. Renaissance self-fashioning: from More to Shakespeare. Chicago: University of Chicago Press.

Griffin, Clive. 1988. The Crombergers of Seville: The History of a Printing and Merchant Dynasty. Oxford: Clarendon Press.

Guerrini, Luigi. 2008. "The 'Accademia dei Lincei' and the New World” Preprint Max-PlanckInstitut, V.348: 1-34, http://edoc5.gwdg.de/360761 Last accessed 10 January 2021.

Hamilton, Earl. 1934. American Treasure and the Price Revolution in Spain, 1501-1650. Cambridge: Harvard University Press.

Jasso, Karla. 2013. Arte-Tecnología: Arqueología Dialéctica Mediación. Ebook: Monoskop Arts. https://monoskop.org/Jasso_Karla_Arte-tecnologia.pdf Last accessed 10 January 2021.

Jakobson, Roman. 1971. "On Linguistic Aspects of Translation," Selected Writings vol. 2: Word and Language. The Hague: Mouton, 260-266.

King, Elizabeth. 2002. "Clockwork Prayer: A Sixteenth-century Mechanical Monk." Blackbird: An Online Journal of Literature and the Arts 1.1 (2002): 1-29.

Kirwan, Richard. 2016. Scholarly Self-Fashioning and Community in the Early Modern University. London: Taylor \& Francis.

Leicht, Hugo. 1967 [1909]. Las calles de Puebla: estudio histórico. Puebla: Comisión de Promoción Cultural del Gobierno del Estado de Puebla.

Leichtentritt, Hugo. 1934. "Mechanical Music in Olden Times.” The Musical Quarterly 20.1: 15-26. Leonard, Irving. 1971. Baroque Times in Old Mexico; Seventeenth-century Persons, Places, and Practices. Ann Arbor: University of Michigan, 1971.

— . 1947. "On the Mexican Book Trade, 1683." The Hispanic American Historical Review 27.3: 403-435. 
Luciani, Frederick. 2004. Literary Self-fashioning in Sor Juana Inés de la Cruz. Lewisburg: Bucknell University Press.

Mădălina, R. 2009. "On the Classification of Proverbs.” Translation Studies: Retrospective and Prospective Views. 2.5: 119-125.

Maillard Álvarez, Natalia. 2014. "Italian Literature in the Hispanic World during the Early Modern Period: Seville and Mexico City," Books in the Catholic World during the Early Modern Period. Leiden: Brill, 115-144.

More, Anna. 2012. Baroque Sovereignty: Carlos de Sigüenza y Góngora and the Creole Archive of Colonial Mexico. Philadelphia: University of Pennsylvania, 2012.

Nesvig, Martin. 2009. Ideology and Inquisition: The World of the Censors in early Mexico. Yale University Press.

Osorio Romero, Ignacio. 1993†. La Luz Imaginaria: Epistolario de Atanasio Kircher con los novohispanos. México: Universidad Nacional Autónoma de México.

— . 1994†. "Los escritos científicos de Alexandro Favián y su relación con Atanasio Kircher," Saber Novohispano 1.1: 81-88.

— . 1989. Conquistar el eco: la paradoja de la conciencia criolla. México: Universidad Nacional Autónoma de México.

Pardo-Tomás, José. 2016. “Making natural history in New Spain, 1525-1590.” In The Globalization of Knowledge in the Iberian Colonial World, ed Helge Wendt. Berlin: Max Planck Institute, 29-51.

Peterson, Andrew Christian. 2014. Making the first Global Trade Route: The Southeast Asian foundations of the Acapulco-Manila Galleon Trade, 1519-1650. PhD Diss. University of Hawai'i at Manoa.

Porter, Catherine. 2013. "Translation as Scholarship.” Esther Allen and Susan Bernofsky, eds. In translation: Translators on their work and what it means. New York: Columbia University Press, 58-66.

Prieto, Andrés. 2011. Missionary Scientists: Jesuit Science in Spanish South America, 15701810. Nashville: Vanderbilt University Press.

Restrepo, Luis Fernando. 2014. "The Cultures of Colonialism." The Companion to Latin American Studies. London: Routledge, 59-80.

Ríos Castaño, Victoria. 2018. "The Herbal of the Florentine Codex: Description and Contextualization of Paragraph V in Book XI.” The Americas 75.3: 463-88.

—. 2015. "Sahagún's Sixteenth-Century Translation Techniques." Journal of Iberian and Latin American Research 21.2: 199-212.

Rodríguez-Medina, Leandro, et al. 2019. "International Ties at Peripheral Sites: Co-producing Social Processes and Scientific Knowledge in Latin America.” Science as Culture 28.4: 562-588. 
Rubial García, Antonio. 2016. “El episcopado criollo de la Nueva España (1593-1743)," La dimensión imperial de la Iglesia novohispana, (eds.) Cervantes Bello, Francisco J., and María del Pilar Martínez López-Cano. México: Universidad Nacional Autónoma de México, 73114.

Rubiés, Joan-Pau et. al. 2020. "Introduction: Early Catholic Orientalism and the Missionary Discovery of Asian Religions," Journal of Early Modern History 24.6: 463-470.

Rueda-Ramírez, Pedro. 2004. "El comercio de libros con América en el siglo XVII: El Registro de Ida de Navíos en los años 1601-1649.” Tiempos Modernos: Revista Electrónica de Historia Moderna 11: n.p.

— and Idalia García Aguilar. 2009. "El comercio de libros en Latinoamérica colonial: aproximación al estado de la cuestión (siglos XVI-XVIII)." Complejidad y materialidad: reflexiones del seminario del libro antiguo. México: UNAM, 193-279.

Ruiz Martínez, R., and Juan Manuel Armenta Olvera. 1992. Las capillas del vía crucis en Puebla: Su historia. México: Gobierno del Estado de Puebla, Secretaría de Cultura.

Schechner, Sara. 2005. "Between Knowing and Doing: Mirrors and their Imperfections in the Renaissance." Early Science and Medicine 10.2: 137-162.

Sepibus, Georgius de, and Athanasius Kircher. 2015. The Celebrated Museum of the Roman College of the Society of Jesus: A Facsimile of the 1678 Amsterdam Edition of Giorgio de Sepi's Description of Athanasius Kircher's Museum, Musaum Celeberrimum Collegii Romani Societatis Jesu. Philadelphia: Saint Joseph's University Press.

Steadman, Philip. 2021. Renaissance Fun. London: UCL Press.

Stolzenberg, Daniel. 2001. The Great Art of Knowing: The Baroque Encyclopedia of Athanasius Kircher. Stanford: Stanford University Libraries.

—. 2013. Egyptian Oedipus: Athanasius Kircher and the Secrets of Antiquity. Chicago: University of Chicago.

Sturge, Kate. 2008. "Cultural Translation,” Routledge Encyclopedia of Translation Studies. Eds. Mona Baker and Gabriela Saldanha. London: Taylor \& Francis Group.

Toribio Medina, José. 1991. La imprenta en la Puebla de los Ángeles (16401821). México: Universidad Nacional Autónoma de México.

Trabulse, Elías. 1983. Historia de la ciencia en México: Siglo XVII, El claroscuro de la ciencia mexicana del siglo barroco. México: Fondo de Cultura Económica.

—. 1994a. Los orígenes de la ciencia moderna en México (1630-1680). México: Fondo de Cultura Económica.

—. 1994b. Ciencia y tecnología en el Nuevo Mundo. México: Colegio de México.

—. 1985. La ciencia perdida. México: Fondo de Cultura Económica.

Udías, Agustín. 2020. "Athanasius Kircher and Terrestrial Magnetism: The Magnetic Map.” Journal of Jesuit Studies 7.2: 166-184. 
Van Cleempoel, Koenraad. 2009. "Philip II's Escorial and Its Collection of Scientific Instruments." European Collections of Scientific Instruments, 1550 - 1750. Eds. Strano, Giorgio, et al. Leiden: Brill, 101-127.

Varey, Simon, et al. 2000. The Mexican Treasury: The Writings of Dr. Francisco Hernández. Stanford: Stanford University Press.

Venuti, Lawrence. 1995. The Translator's Invisibility, London: Routledge.

Villella, Peter. 2016. Indigenous Elites and Creole Identity in Colonial Mexico, 15001800. Cambridge: Cambridge University Press.

Vonk, Roos. 2002. "Self-serving Interpretations of Flattery: Why Ingratiation Works." Journal of Personality and Social Psychology 82.4: 515ff.

Ward, Haruko. 2016. Women Religious Leaders in Japan's Christian Century, 1549-1650. London: Routledge.

Zelechow, Bernard. 1993. "The Myth of Translatability: Translation as Interpretation." Translating Religious Texts. Palgrave Macmillan, London, 122-139. 